\title{
8662
}

.8662 au of Mines Information Circular/1974

\section{The Flathead Tunnel}

A Geologic, Operations, and Ground Support Study, Burlington Northern Railroad, Salish Mountains, Montana 
ERANK MELVILISB JR.

MEMORIAL IIBRARY

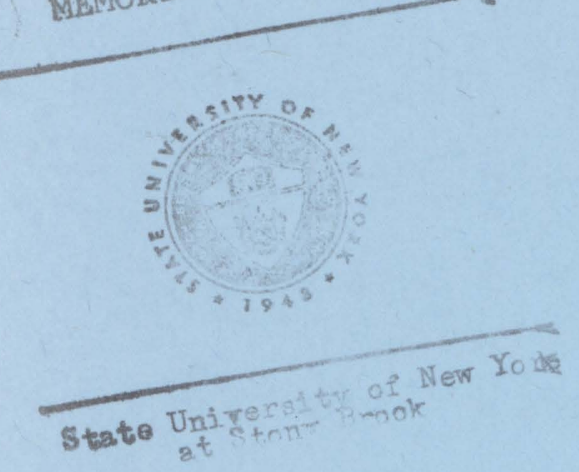


Information Circular 8662

\section{The Flathead Tunnel}

A Geologic, Operations, and Ground Support Study, Burlington Northern Railroad, Salish Mountains, Montana

By Eugene H. Skinner

Spokane Mining Research Center, Spokane, Wash.

UNITED STATES DEPARTMENT OF THE INTERIOR Rogers C. B. Morton, Secretary

Jack W. Carlson, Assistant Secretary-Energy and Minerals BUREAU OF MINES

Thomas V. Falkie, Director 
As the Nation's principal conservation agency, the Department of the Interior has responsibility for most of our nationally owned public lands and natural resources. This includes fostering the wisest use of our land and water resources, protecting our fish and wildlife, preserving the environmental and cultural values of our national parks and historical places, and providing for the enjoyment of life through outdoor recreation. The Department assesses our energy and mineral resources and works to assure that their development is in the best interests of all our people. The Department also has a major responsibility for American Indian reservation communities and for people who live in Island Territories under U.S. administration.

This publication has been cataloged as follows:

\section{Skinner, Eugene H}

The Flathead tunnel: a geologic, operations, and ground support study, Burlington Northern Railroad, Salish Mountains, Montana. [Washington] U.S. Bureau of Mines [1974]

98 p. illus., tables. (U.S. Bureau of Mines. Information circue lar 8662)

Includes bibliography.

1. Tunnels. 2. Tunneling. I. U.S. Bureau of Mines. II. Title. III. Title: Burlington Northern Railroad. (Series)
TN23.U71
no. 8662
622.06173

U.S. Dept. of the Int. Library

For sale by the Superintendent of Documents, U.S. Government Printing Office

Washington, D.C. 20402 - Price $\$ 2.55$

Catalog No. 128.27:8662

Stock Number 2404-01719 


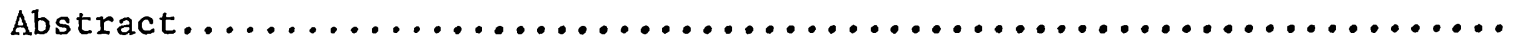

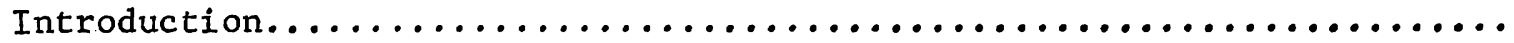

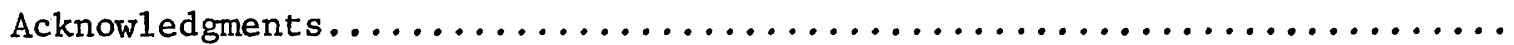

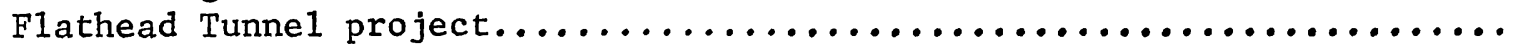

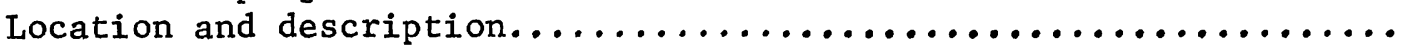

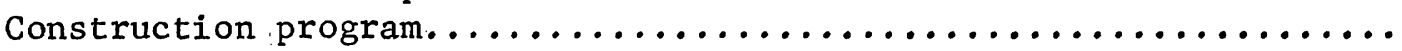

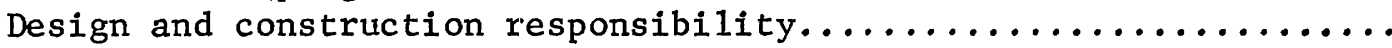

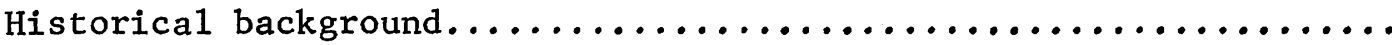

Physiographic locality...............................

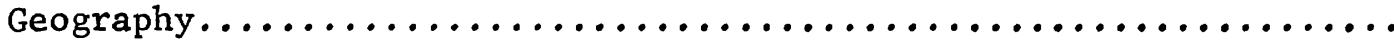

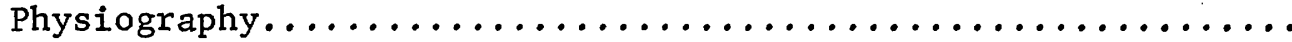

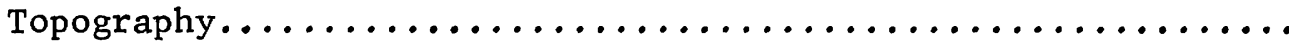

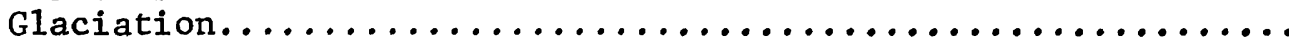

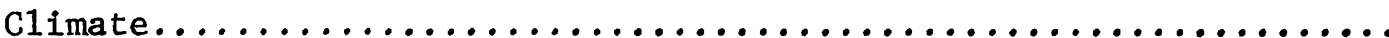

Belt series.

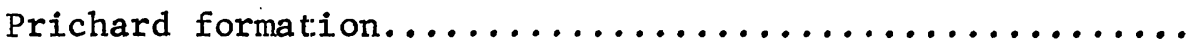

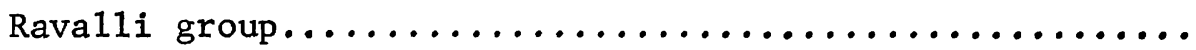

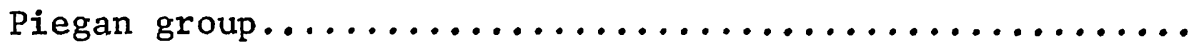

Lower Piegan..........................

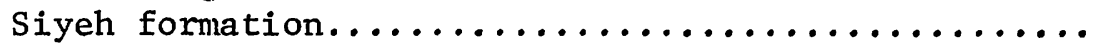

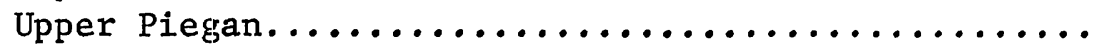

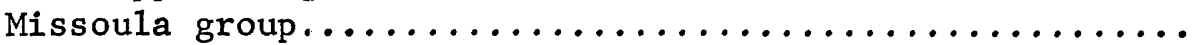

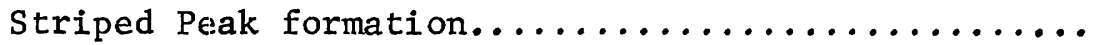

Libby formation........................

Igneous rocks................................

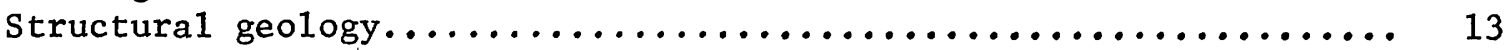

Fau1ting............................................ 13

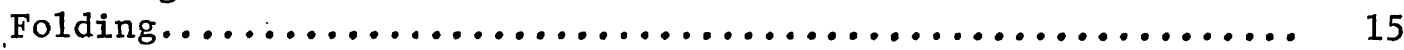

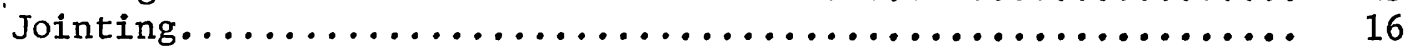

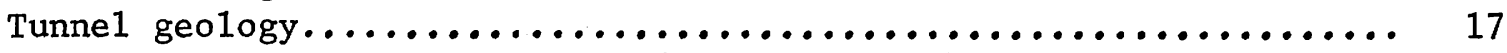

Station 3003 to station 3081 (7,800 feet).............. 17

Station 3081 to station $3106(2,500$ feet $) \ldots \ldots \ldots \ldots \ldots \ldots \ldots \ldots \ldots$

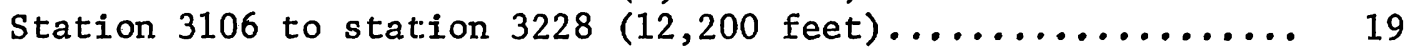

Station 3228 to station $3356(12,800$ feet $) \ldots \ldots \ldots \ldots \ldots \ldots \ldots \ldots . \ldots \ldots$

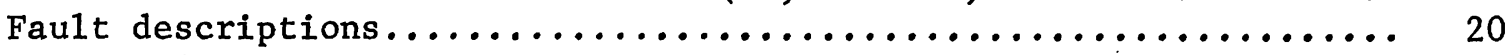

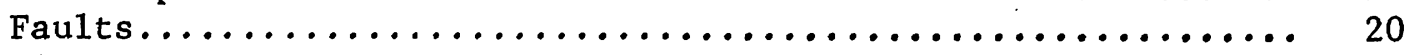

E1k Mountain Fault............................. 20

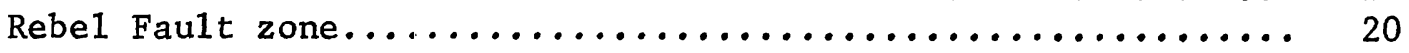

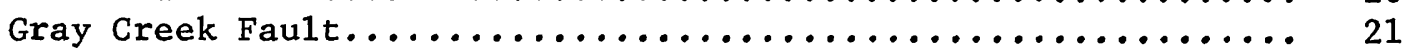

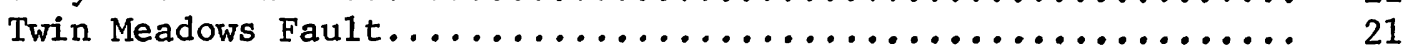

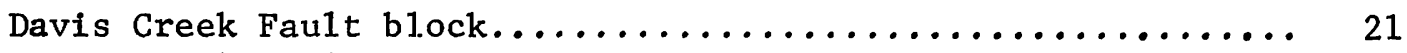

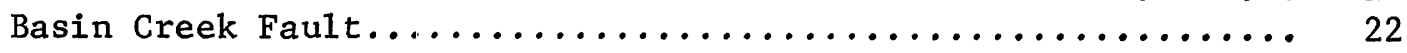

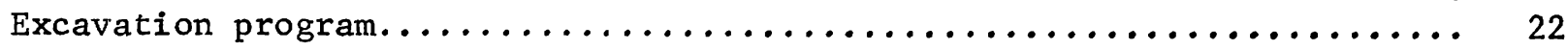

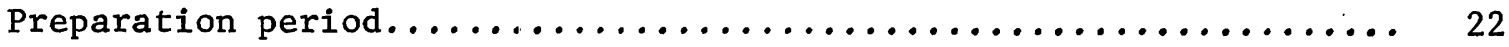

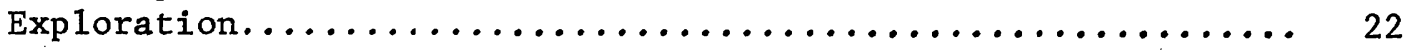

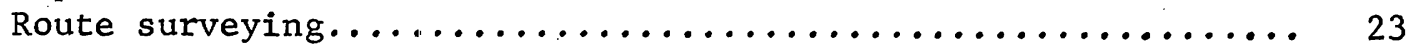


CONTENTS --Continued

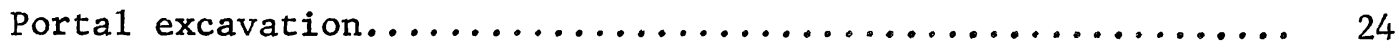

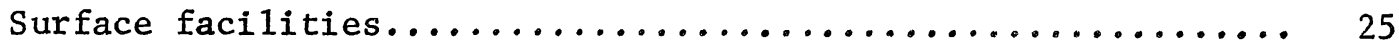

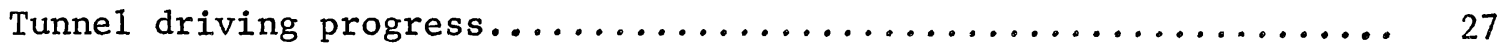

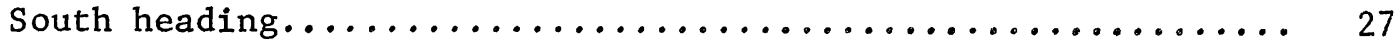

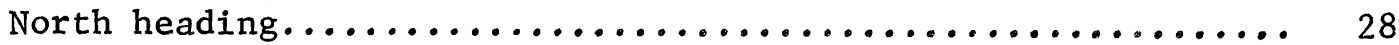

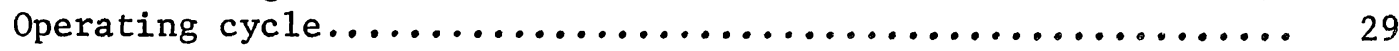

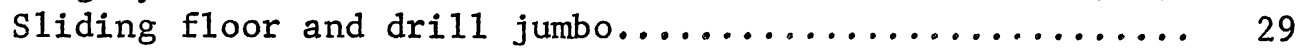

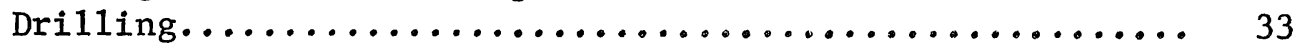

Explosives and blasting..................... 33

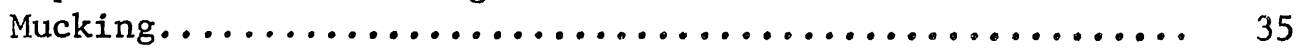

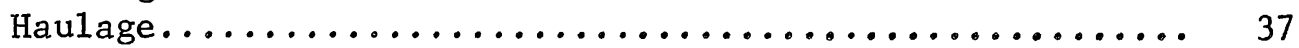

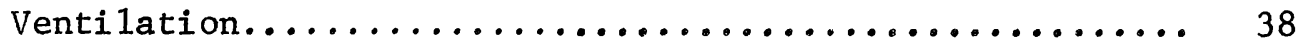

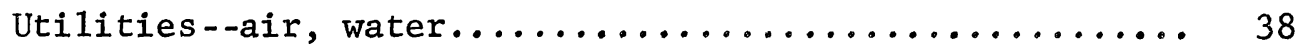

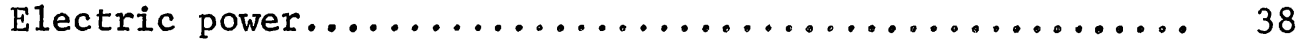

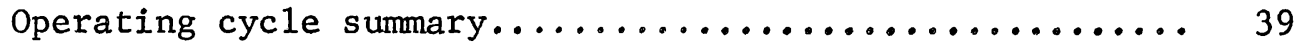

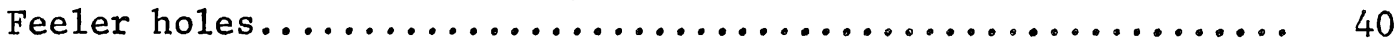

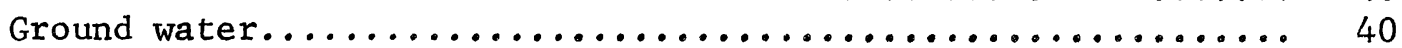

Smooth-wall blasting........................... 40

Laser surveying............................. 42

The ground support program............................ 43

Temporary support.............................. 43

Support selection............................ 43

Structural stee1 support......................... 45

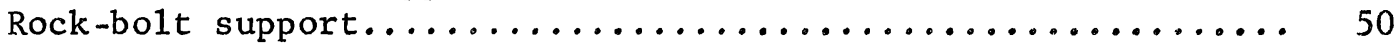

Special problems (tunne1)....................... 53

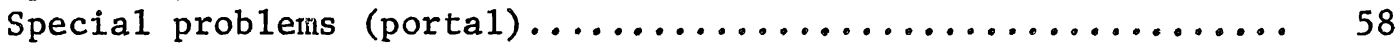

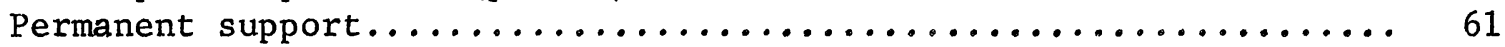

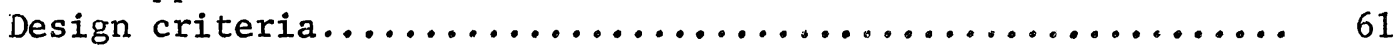

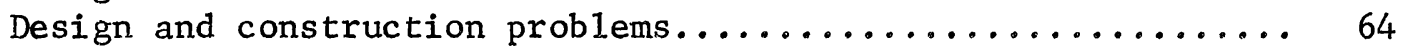

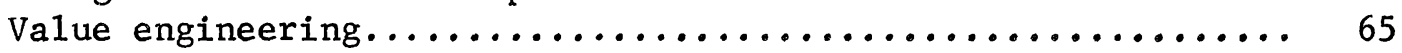

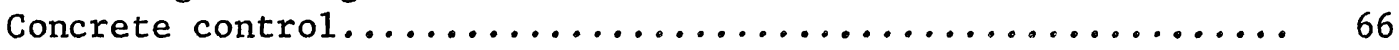

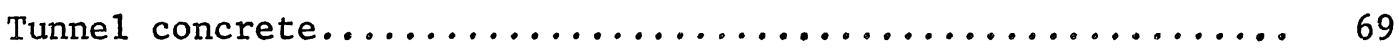

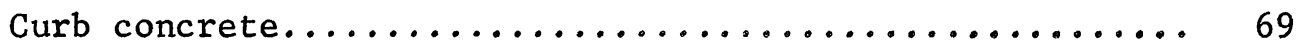

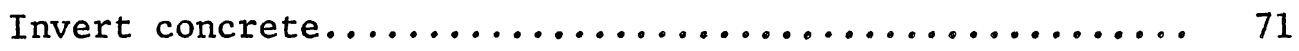

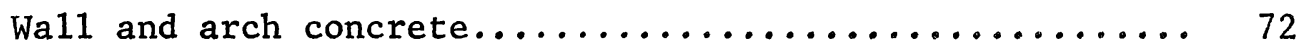

Temporary support instrumentation..................... 77

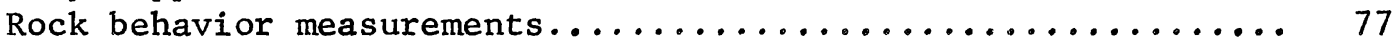

Support load measurements...................... 83

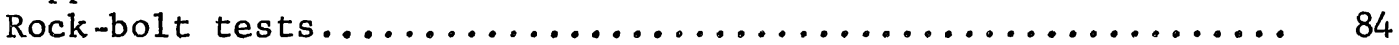

Physica1 properties............................ 85

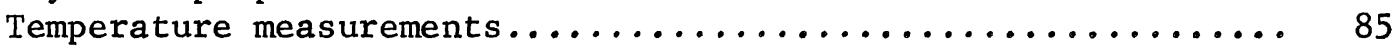

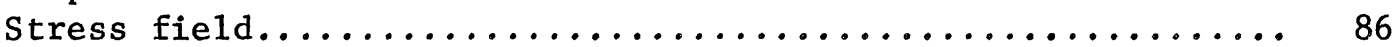

References...................................... 88

Appendix A--Project summary............................ 92

Appendix B--Safety................................... 96

Appendix $\mathrm{C}-$-World railroad tunnels......................... 98 
1. South porta1, Flathead Tunne1........................

2. North porta1, Flathead Tunne1........................

3. Generalized stratigraphy of Salish Mountains.................

4. Geologic map and section of a portion of eastern Lincoln County and western Flathead County, Mont................. pocket

5. Flathead Tunnel profile........................... 18

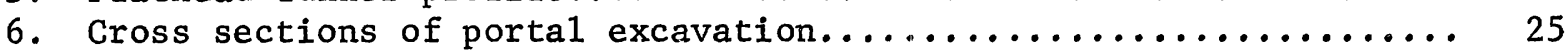

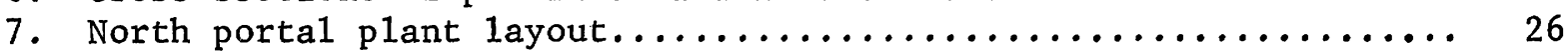

8. General dimensions of sliding floor.................... 30

9. Rear view of jumbo and sliding floor................... 31

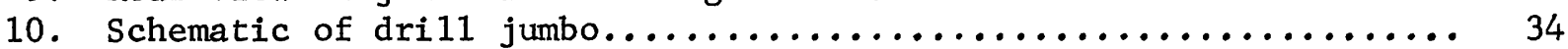

11. Side view of drill jumbo........................... 34

12. Typical dril1 round pattern........................ 35

13. Muck pile at final round, station $3157+01 \ldots \ldots \ldots \ldots \ldots \ldots \ldots \ldots \ldots . \ldots \ldots$

14. Typical mucking equipment layout..................... 37

15. Typical dimensions for steel sets...................... 44

16. Steel support in north heading........................ 45

17. Rock-bolt anchorage for support legs................... 46

18. Distribution of tunnel lengths supported with 6 -inch sets....... 47

19. Distribution of tunne 1 lengths supported with 8 -inch sets........ 49

20. Distribution of tunnel lengths supported with invert struts...... 49

21. Typical arch rock before rock bolting................... 51

22. Typical rock-bolted section in north heading............... 53

23. Distribution of rock-bolt support...................... 54

24. Collapsed tunnel supports.......................... 55

25. Completed repair of rockfa11 section.................... 56

26. Cross sections of tunnel collapse zone.................. 57

27. Burrows Creek slide.............................. 59

28. Burrows Creek backfill section........................ 61

29. Cut-and-cover construction, north portal................ 62

30. Typical concrete-1ined tunnel section.................. 63

31. Completed concrete-1ined tunne1 section.................. 63

32. North portal concrete batching plant.................... 68

33. Aerial view of north porta1......................... 69

34. Invert curb formwork........................... 70

35. Typical concrete formwork section at north porta1........... 73

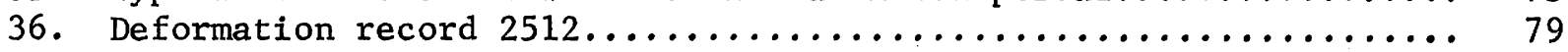

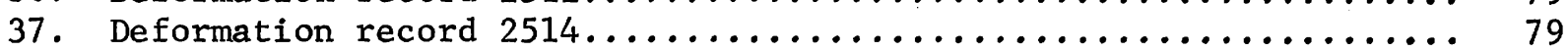

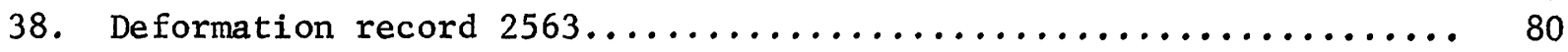

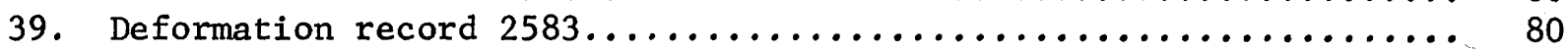

40. Normalized displacement with respect to tunnel rib............ 82

A-1. Schedule of major tunnel activities..................... 94

\section{TABLES}

1. Drill holes for tunnel exploration..................... 23

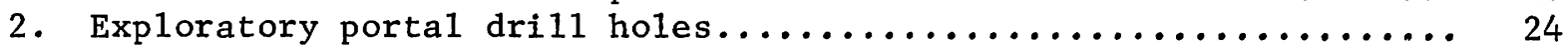

3. Tunne1 driving progress, south heading................... 27 
TABLES - -Continued

$\underline{\text { Page }}$

4. Tunne1 driving progress, north heading................... 28

5. Time study of excavation cycle per round.................. 39

6. Steel sets insta1led, Flathead Tunne1.................... 50

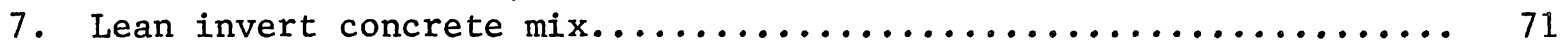

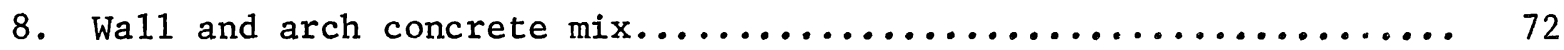

9. Weekly wal1 and arch concrete lining progress............... 76

10. Installation data, selected MPBX stations................. 78

11. NX core samples, quartzitic argillites................... 85

A-1. Project summary............................... 92

A-2. Select tunnel bid items............................ 93

A-3. Summary of excavation and support costs................... 94

A-4. Tunnel excavation equipment, each heading................. 95

B-1. Accident statistics, Flathead Tunne1..................... 96

C -1 . World railroad tunnels............................. 98 


\title{
THE FLATHEAD TUNNEL
}

A Geologic, Operations, and Ground Support Study, Burlington Northern

Railroad, Salish Mountains, Montana

by

Eugene H. Skinner ${ }^{1}$

\begin{abstract}
The 7 -mile Flathead Tunnel, located in the central Salish Mountains of northwestern Montana, was constructed between 1966 and 1969. With the contract awarded Apri1 19, 1966, drill and blast tunnel excavation began September 30, 1966, and was completed June 21, 1968, in 488 tunnel-driving days. Peak advance was 66 feet per day. On June 27, 1969, a11 tunnel concrete lining was completed. Average wall and arch concrete placing rates exceeded 1,700 cubic yards daily, with nearly half of the concrete placed during a severe winter season. Major cost savings in concrete tunnel lining were achieved through a value engineering clause in the contract. Achieving consistent results and high rates of placement in concrete lining ranked equal to ground control in overall tunnel problems.

Ground control problems exceeded expectations and were of continual concern throughout excavation. One support collapse in the tunnel and one portal slide condition developed during construction. Critical surface geologic exposures were largely obscured; only a portion could be accurately projected underground. An instrumentation program to gather basic data on rock deformation near the heading face for support purposes was a pioneering effort. The Flathead Tunnel was placed in service on November 7, 1970.

\section{INTRODUCTION}

This report is one of a series of selected Information Circulars published by the Bureau of Mines in the general subject area of tunneling methods and costs in the United States. The Flathead Tunnel directly resulted from the signing of the Columbia River Treaty on September 16, 1964. This treaty essentially provided for cooperation in water resource development and regulation of the Columbia River Basin. In Canada, Mica, Duncan, and High Kennleyside (formerly Arrow) Dams were constructed. In the United States, construction of the Libby Dam and the third powerhouse of Grand Coulee Dam was authorized by Congress in June 1966 .
\end{abstract}

\footnotetext{
${ }^{2}$ Mining engineer.
} 
Construction of the Libby Dam began in the summer of 1966, and major portions of the dam were completed by 1973. Water was impounded in the spring of 1972. The dam and reservoir are a major unit in the comprehensive development of the Columbia River Basin and will have multiple-purpose flood control, power generation, and recreation capability. Technical details of dam construction beyond the scope of this report are available (ㅁ, $11, \underline{21}, \underline{47}) .^{2}$

The Libby Dam Project had been authorized by Congress in the Flood Control Act of 1950, Public Law 516, 81st Congress. Preliminary planning started in 1952, but was terminated in 1954. Some route selection and preliminary planning for the Flathead Tunnel were done during that time. No further work was done until 1961, when further studies and planning were initiated prior to the present treaty.

One of the first items of work necessary for the Libby Dam Project was relocation of about 60 miles of the Burlington Northern Railway's ${ }^{3}$ main transcontinental rail line. This relocation required 36,955 feet of single-track tunne1. The contract for tunnel excavation was awarded Apri1 19, 1966, and the successful bidder began work at the site May 12, 1966. The first tunnel round was detonated in the south heading September 30, 1966. The tunnel was holed through on June 21, 1968. Concreting of the tunnel lining was completed June 27, 1969. Regular mainline service of the Burlington Northern was inaugurated over the new route November 7,1970 . The Flathead Tunnel received the National Society of Professional Engineers' 1970 award as one of the year's outstanding engineering achievements. It is the second longest railroad tunnel on the North American Continent, exceeded in length only by the 7.79-mile Cascade Tunnel (1926-29) in Washington. Both tunnels are operated by the Burlington Northern Railroad.

This Information Circular is a Bureau of Mines review of tunneling practices typical of the late 1960 's. The report provides reference to a11 pertinent data related to the geology, mining operations, and ground support practices for the Flathead Tunnel. In addition, many factors influencing construction decisions are outlined. Parts of the report are written to further aid the study of tunneling in the manner of operations research. Comparison of Flathead Tunnel construction with that of the Cascade Tunne1 $(27,30)$, completed less than 40 years before, provides a useful analysis of advances in tunneling technology. It is hoped that the information reported herein will inform and stimulate the mining and tunneling community.

\section{ACKNOWLEDGMENTS}

This report is dedicated to the miners, crafts, supervisors, engineers, and management who brought this project to a successful completion. Among those acknowledged for their contribution are P. L. Cole, resident engineer,

Underlined numbers in parentheses refer to items in the 1 ist of references preceding the appendixes.

${ }^{3}$ The Northern Pacific, Great Northern, and Chicago, Burlington and Quincy Railroads were merged into the Burlington Northern Railroad by action of the United States Supreme Court, Feb. 2, 1970. 
Libby Project, Corps of Engineers; L. E. Huntington, project manager, WalshGroves; and C. F. Intlekofer, manager of engineering, Seattle, Burlington Northern, Inc. Many others contributed their time and effort toward furnishing data for this report. Recognition is extended to the following: $R . D$. Bush, Chief, Instrumentation Section, Libby Project, Corps of Engineers; W. H. Eschwig, resident engineer, Libby line change, Burlington Northern, Inc; R. W. Galster, geologist, Seattle District, Corps of Engineers; R. K. Leatherman, Chief, Tunnel Section, Libby Project, Corps of Engineers; J. C. Richards, project geologist, Libby Project, Corps of Engineers; H. E. Sacrison, project engineer, Walsh-Groves; and T. L. Samuelson, Chief, Design Section, Seattle District, Corps of Engineers.

Special acknowledgment is given H. E. Sacrison and the American Society of Civil Engineers (ASCE) for permission to freely abstract portions of the concrete operations from copyrighted material (4).

The Bureau of Mines is appreciative to the Seattle District, Corps of Engineers, and Burlington Northern, Inc., for generous cooperation in making available the construction records necessary for this report and for permission to publish them.

FLATHEAD TUNNEL PROJECT

Location and Description

The Libby Dam is located on the Kootenai River about 17 miles upstream from Libby, Mont., and 3-1/2 miles above the mouth of the Fisher River. The relocated railroad route, a few miles east of Libby and south of the damsite, follows Fisher River for about 11 miles and thence up Wolf Creek, proceeding east and northeast for about 29 miles and gaining nearly 1,000 feet of altitude at the west tunnel portal near the head of Wolf Creek. Beyond the east portal, the route proceeds northeastward following Fortine Creek downstream about 17 miles to Stillwater Valley near Stryker, about 28 miles northwest of Whitefish, Mont. Maximum ruling grades do not exceed 1.0 percent along the entire $59.35-$ mile relocated route.

The 7 -mile tunnel passes in close proximity beneath the drainage divide (elevation 3917 feet) of the Salish Mountains between the headwaters of Fortine Creek on the east and Wolf Creek on the west. For the first twothirds of its eastern length, it passes under hummocky topography of moderate relief. The southern third passes under the northwest shoulder of Elk Mountain (elevation 6,587 feet) and emerges at the south portal (fig. 1) in the valley of Wolf Creek. The tunnel extends from station $2988+75$ at the north portal (elevation 3,692 feet) to station $3358+25$ at the south portal (elevation 3,524 feet). Total length of tunnel is 36,955 feet, including portal cut-and cover sections. The tunnel orientation is very nearly true northsouth (although railroad terminology is based on an east-west direction of trave1).

The north portal, on the eastern entrance for the railroad, is in the NW1/4 of section $8, T 32 \mathrm{~N}, \mathrm{R} 26 \mathrm{~W}$ (unsurveyed). The south portal, on the 


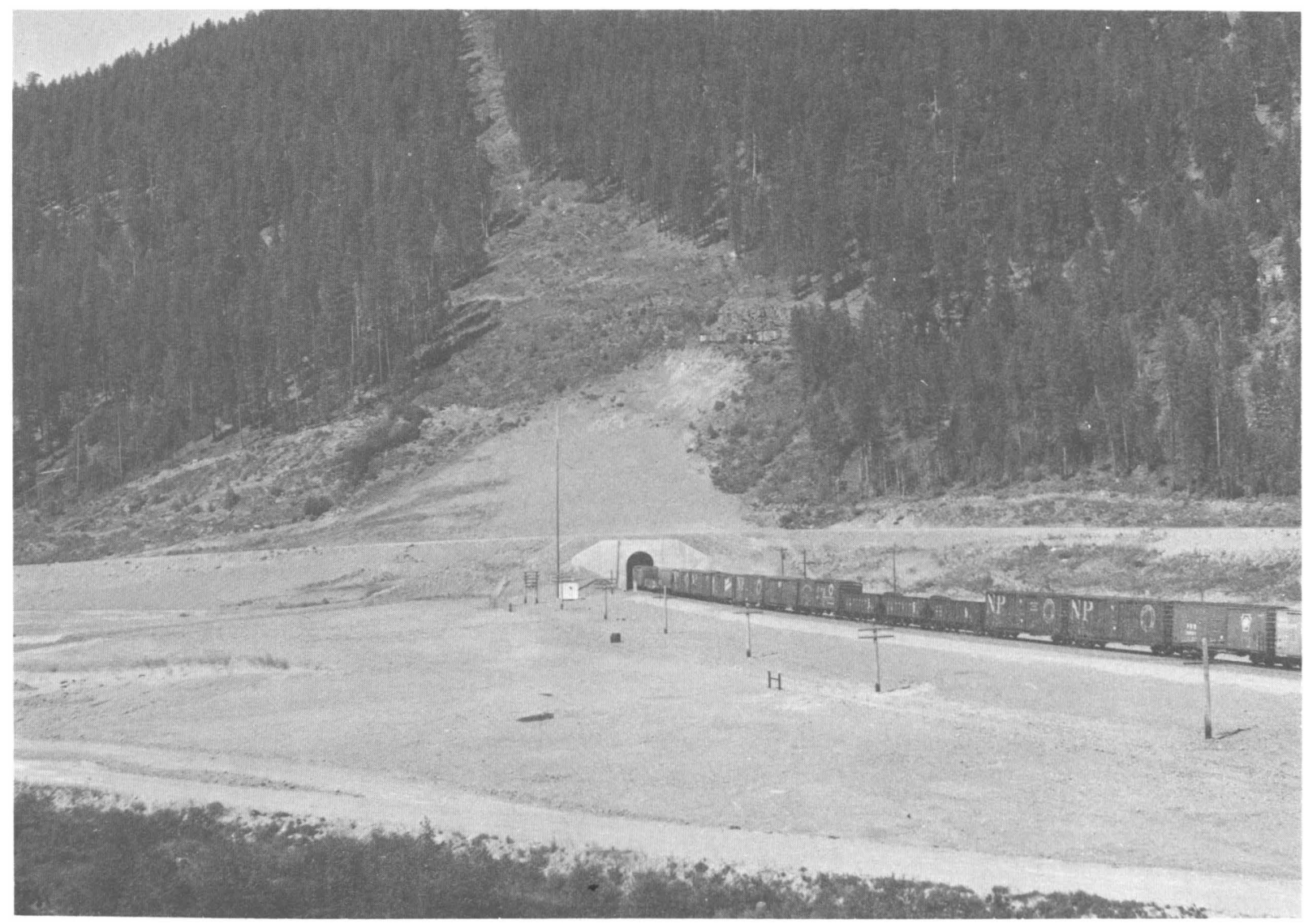

FIGURE 1. - South portal, Flathead Tunnel.

western entrance for the railroad, is in the SE1/4 of section $17, \mathrm{~T} 31 \mathrm{~N}$, R $26 \mathrm{~W}$ (Montana Principal Meridian). The entire route is shown on the Bowen Lake (1963) and Skillet Mountain (1963) 7.5-minute topographic maps of the U. S. Geological Survey.

The tunnel is horseshoe shaped, single track, straight, and concrete1ined, with a uniform grade of 0.46 percent descending 168 feet from the north portal to the south portal. A shallow, vertical curve occurs outside both portals in the railroad grade. Short sections of cut-and-cover construction, using reinforced concrete, are at each portal. Refuge chambers and transformer bays were also provided along the tunnel. The tunnel is constructed according to standards of the Burlington Northern Railroad and American Railway Engineering Association (AREA). Several aspects of tunnel construction have been reviewed (느, $\underline{21}, \underline{29}, \underline{38}, \underline{44}, \underline{46})$.

Other aspects of the Flathead Tunnel project are also of great technical achievement, but are outside the area of interest for this report. One of these is related to the north portal ventilation system (1), and another describes the automatic track-laying operation used for the final stage of track construction $(10,32,40)$. Most of the ventilation structure for the Flathead Tunnel is shown in figure 2 (note ventilation exhaust fans on 1 eft). 


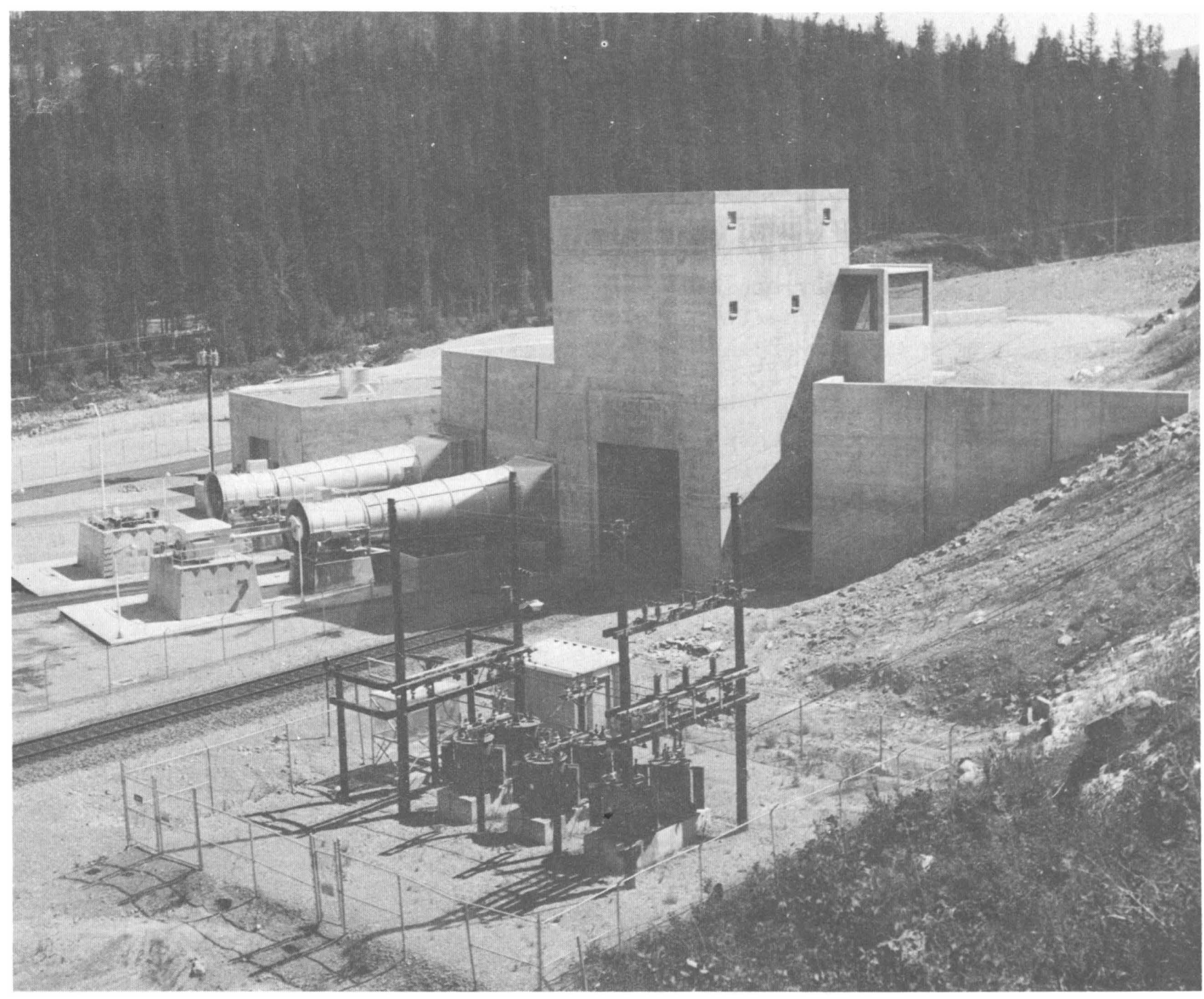

FIGURE 2. - North portal, Flathead Tunnel.

\section{Construction Program}

As compensable interest for the inundated portion of railway, the government was obligated to provide a necessary relocation. The Corps of Engineers, Seattle District, awarded the construction contract for the Flathead Tunnel and approaches to Walsh Construction Co.-S. J. Groves and Sons (Wa1sh-Groves joint venture) on April 19, 1966. The bid was $\$ 43,906,727$ and was to be completed in 1,250 calendar days (December 2, 1969). Actual site work began May 12, 1966. Final contract closing cost, to include change orders, was $\$ 45,395,329.21$, on November 25, 1969 .

The low bid of Walsh-Groves was 24 percent above the $\$ 35.273$ million cost estimate by the Government. Only two other bidders responded to this project. They were joint ventures of Peter Kiewit, C. J. Langefelder, and J. F. Shea, at $\$ 47.880$ million, and Morrison Knudsen, Perini Corp., Brown \& Root, F\& S Contracting, and McLaugh1in, Inc., at \$49.476 miliion. 


\section{Design and Construction Responsibility}

The Burlington Northern Railroad furnished design criteria for construction of the tunnel project. This work was under the direct supervision of the Corps of Engineers, Seattle District. The Burlington Northern worked closely with the Corps of Engineers in tunnel design concept and specifications. The Burlington Northern maintained a project engineer and staff of field engineers at the site to provide liaison and assist the Corps of Engineers in meeting specifications. Especially monitored were construction details that would later affect operation of the tunnel. The Corps of Engineers established a Resident Engineer's office at the Libby Dam site and provided complete office and field engineering inspection staff for the tunnel project.

Project studies by the Corps of Engineers included an extensive number of field and office investigations. Continuous liason was maintained with engineering and operating officials of the Burlington Northern staff, in both Seattle and St. Paul. Liason was also maintained with the U. S. Forest Service and agencies of the State of Montana. Outside consultant services were used for route selection, railroad operations, tunneling, and a proposal from a tunnel boring firm. Many other work items, too numerous to mention, such as power relocation, were done by the owning agency.

In 1958, prior to active tunnel work, the Burlington Northern, Pacific Power and Light, and Montana Bureau of Mines began a regional geologic survey project. The objective was to map and make available to the general public as much geological information as possible in northwestern Montana. Most of this work was concluded in 1970 (25) with nine reports being published in the series by the Montana Bureau of Mines. These reports provide a cumulative bibliography in excess of 225 references to the geology of northwestern Montana.

\section{Historical Background}

The Kootenai River is central to the early history of the Pacific Northwest. The route across the Salish Mountains was also important to the western development of the (former) Great Northern Railway. A brief historical resume of this particular route is appropriate for this report.

Very shortly after Lewis and Clark traversed the region, a few hundred miles to the south, Canadian fur traders crossed the Rocky Mountains and began exploration southward to the Kootenai River region. These were the first recorded expeditions into the interior of the present northwestern United States. The particular explorations of David Thompson are especially pertinent to this report for his precise surveyed locations and his written journals. On one of these many minor explorations, Thompson traversed the Thompson River-Fisher River route in October 1808 (7, pp. 672-674). Thompson's later map of the region (one version came to be known as the Arrowsmith map of London) shows knowledge of the unique Fisher River-Wolf Creek-Fortine Creek drainage system. 
The Kootenai River locality appears to have been the site of fur-trading efforts dating from Thompson's first explorations when trading was established near Jennings, Mont., and later moved northward to Fort Steele in Canada. The Jesuit missionaries, beginning in the $1840^{\prime} \mathrm{s}$, apparently used the Wolf CreekFortine Creek route in their annual travels among the Kootenai Indians (26, p. 12).

In 1853, the first of three North Pacific railroad surveys across the northern Rocky Mountains was made under the direction of Col. Isaac I Stevens. A portion of this survey, by Lt. John Mullan in the fall of 1854, traversed the Fortine Creek-Wolf Creek divide, but the availability of easier routes to the south precluded recommendation for this route at the time. In 1860 the official boundary survey completed that section between the Columbia River and what is now Glacier National Park.

The gold strike at Wild Horse in Canada led to further exploration of the area in the $1860^{\prime} \mathrm{s}$, with placer gold being mined near Libby in 1867 . It was not until gold was discovered at Murray, Idaho, in 1884, that the largest influx of prospectors occurred in the Kootenai area. Shortly afterward, the Great Northern Railroad began surveying a route from the Montana plains to Seattle.

Previous knowledge of the region, such as just described, was undoubtedly reviewed by the Great Northern. Railway engineering department in their quest for a route through the Salish Mountains, although it certainly had to be verified for suitability as a railroad route. In December 1889 , John F. Stevens located Marias Pass (elevation 5,213 feet) in Montana, and the following year also located Stevens Pass (elevation 4,057 feet) in Washington. Charles F. B. Haske11 (1856-95) was assigned exploration of the Salish Mountain route in early 1890. It is noted that all these routes were located during winter conditions, and certainly these efforts rank among the greatest achievements of route location in American railroading. The railroad buff may find further documentation of winter operating conditions through these passes in a book by Wood (48).

Haske11 and two other surveyors made a 52-day exploration of the Salish Mountain region between January 29, 1890, and March 21, 1890 (19, p. 67). That they endured temperatures (as recorded at Kalispe11) of $-44^{\circ} \mathrm{F}$, and that the only supplies they carried. were those on their backs, is certainly commendable. Haske11 Pass, above Marion, is named for Charles Haskel1.

Evidence indicates $(\underline{26}$, p. 177) that Haske11 had traversed the Fortine Creek-Wolf Creek route, but for reasons probably contained in his instructions to seek the shortest route and easiest grades, he chose the route through Haske11 Pass, which was completed in 1892. In 1902, track was completed along the Kootenai River from Libby, leading to Fernie, and in 1904, the Columbia Falls cutoff route through the Tobacco Plains to Eureka was completed. Shortly thereafter, the steeper grades and switchbacks of the Haskell Pass route were abandoned. 
The present route along Fisher River and Wolf Creek follows Haskel1's route of 1890 for a considerable distance. The old roadbed leading to the present tunnel is visible today in many places along Wolf Creek.

Thus, in 1ittle more than a century after the Kootenai River region became distinguished by some of the very earliest inland exploration in the Pacific Northwest, this particular area also saw completion of the last transcontinental railroad, including the second longest railroad tunnel on the North American Continent.

\section{PHYSIOGRAPHIC LOCALITY}

\section{Geography}

Physiography

Northwestern Montana is characterized by successive north - to northwest trending mountain ranges separated by valleys. Between the western Montana boundary and Glacier Park, at least eight such ranges are present. One of these is the Salish Range, containing the route of the Flathead Tunnel. The Kootenai and Flathead Valleys, to the west and east, respectively, of the Salish Range, are the bounding valleys. Perhaps the most prominent geographic feature 1ies a few miles to the east of Flathead Tunnel, where Daly ( $\underline{8}, \mathrm{p} .26)$ described a remarkably long and straight topographic depression which he named the "Rocky Mountain Trench," occupying the Kootenai Valley in British Columbia and extending southeastward along the Tobacco River and Sti11water Valleys to Flathead Lake, in Montana.

\section{Topography}

Topography within the Salish Mountains in the immediate vicinity of the Flathead Tunnel is generally subdued but locally precipitous with elevations ranging from 5,500 to 6,600 feet, particularly along a mountainous ridge a few miles east of the tunnel route. The highest nearby peak is E1k Mountain, elevation 6,587 feet, about 1 mile east of the south portal. Most peaks are between elevations of 5,000 and 6,000 feet. Elevations in the valleys range from 3,400 to 4,000 feet.

Local relief in the area is approximately 2,500 feet. The tunnel route is drained by Wolf and Fortine Creeks. Streams west of the Salish Mountains have cut up to 1,000 feet deeper (elevations of $+2,000$ feet) than in the Rocky Mountain Trench (elevations of $+3,000$ feet). Most of this can be attributed to greater downcutting by the Kootenai River. Drainage streams generally flow nearly perpendicular to the strike of geologic strata. The Salish Mountains exhibit a mature preglacial topography modified by extensive glaciation.

\section{Glaciation}

In the locality of the Flathead Tunnel, glacial striations and fluting of rock outcrops are evidence of continental glaciation. The Salish Mountains were glaciated at least as far south as E1k Mountain. Even today, Gibson 
(14, p. 7) reports three small permanent glaciers south of Libby in the Cabinet Mountains. The permanent glaciers in Glacier National Park are wel1 known. Previous investigators estimate an ice thickness of at least half a mile (from evidence found at elevations up to 6,000 feet on higher peaks). Possibly there was more than one stage of glaciation. A direction of glaciation (movement) from north to south, and generally slightly southwest, is postulated.

\section{C1imate}

The Burlington Northern Railroad and the Corps of Engineers compiled many climatic observations, although official climate records of the region are sparse. The average annual precipitation recorded at weather stations in the valleys is about 16 to 18 inches. Precipitation at higher elevations is half again to twice as much as in the lower valleys, principally as snow. Although seasonal snowfall at both Kalispe11 and Libby exceeds 5 feet, cumulative snowfall within the mountains may amount to 12 feet. Snow typically remains on the north flanks of mountains until July.

The highest official temperature recorded at Kalispell during the period 1920-69 was $105^{\circ} \mathrm{F}$ in 1961, and the lowest was $-38^{\circ} \mathrm{F}$ in 1950 (45). The record lows have been nearly equaled in many other years, particularly during the last week of December 1968. Most of the very low temperatures occur during storms from the northeast and northwest. Unofficial records taken at jobsite by the contractor indicate a low of $-55^{\circ} \mathrm{F}$ on January 6,1968 . This combination of cold weather and holidays caused a 1 -week shutdown of the project. Jobsite temperatures are reviewed in appendix A (fig. A-1).

\section{REGIONAL GEOLOGY}

\section{Stratigraphy}

\section{Belt Series}

The Belt Series comprise a thick sequence of metasedimentary rocks in central and western Montana recognized as Precambrian in age with the type locality in the Belt Mountains of Montana. The term "Belt Supergroup" has been accepted by the American Commission on Stratigraphic Nomenclature for those Belt rocks comprising the Ravalli, Piegan, and Missoula groups (fig. 3).

Similar-type rocks over widespread areas in northwestern United States and western Canada have led to the recognition of a vast area with thick sedimentary strata of gross 1ithologic and stratigraphic identity (15, 18).

Thickness and lithology of Belt formations vary, and they vary within very short distances, but the greatest changes occur in the Ravalli and Piegan groups to the north and to the east across the Rocky Mountain Trench. The base of the Be1t is not exposed and the upper beds of the Missoula group have been eroded. Wide areas in Western Montana have been so 1ittle 
studied that Belt rocks have not been adequately distinguished and only the most general statements have been published (37, p. 60).4

Most fine-grained clastic beds of the Belt Supergroup consist of material with original textures obscured somewhat by recrystallization, especially clay minerals. However, in general, the overall Belt Series does not show the metamorphism to be expected for rocks of that age. Abundant sedimentary features are distinctive of the entire Belt Supergroup. The finegrained, carbonate-rich rocks grade into clastic rocks. Limestone and dolomite predominate with varying proportions of calcium and magnesium carbonates. Most of the Belt Series consists of fine-grained clastic rocks with few distinguishing characteristics. Throughout the Belt Series, no recognizable unconformities are found, at least within northwestern Montana.

\section{Prichard Formation}

The Prichard formation was named (34, p. 23) for a sequence of argillite and quartz-bearing argillites near Murray, Idaho. Equivalent Prichard strata are exposed throughout Lincoln County, Mont. However, the eastern extent of recognizable Prichard outcrops appears to be along the central part of the Salish Mountains, where faulting has exposed these strata. The Prichard formation outcrops extensively along Wolf Creek and at the south portal locality. Nowhere in Lincoln and Flathead Counties is the base of the Prichard exposed. In the southwest Salish Mountains, Hal1 (17, p. 20) mapped about 4,000 feet of upper Prichard strata. Galster (12) mapped about 1,600 feet of Prichard-type rocks in the vicinity of Elk Mountain. The contact with the overlying Ravalli group is a transition zone, distinguished in the tunnel area by the presence of a 50-foot-thick limestone unit that is considered part of the Raval1i.

\section{$\underline{\text { Raval1i Group }}$}

The Ravalli group was named for a thick sequence of varigated colored Be1t rocks composed largely of quartzites lying to the southeast of Flathead Lake. In the Coeur d'Alene mining district of Idaho, the Ravalli group is divided into, in ascending order, the Burke formation, Revett quartzite, and St. Regis formation ( $\underline{5}, \mathrm{p} .37)$. These lithologies are not recognized as mappable units in Lincoln and Flathead Counties. Gibson (14, p. 12) described undifferentiated Ravalli beds in the Libby quadrangle as equivalent to those in the Coeur d'Alene region.

In the central Salish Mountains, the mapping of Gilmour (16, p. 22), Hall (17, p. 28), and (12) delineated undifferentiated Ravalli strata having a total thickness of 8,000 to 10,000 feet, but the section is not considered complete and thicknesses can be quite variable within relatively short distances. These undifferentiated Ravalli rocks are dominantly quartzitic and

${ }^{4}$ Ross (37) describes Belt strata throughout the United States. Pages 41-57 show tabled series of chemical analyses for Belt rocks; unfortunately, no work has been done at the project site locality. Also 1isted (pp. 11-26) is a stratigraphic correlation for all Belt rocks. No physical properties are listed. 
generally present a homogeneous appearance, but vary from colorful laminated argillites to more thick-bedded quartzites. Ravalli rocks form prominent cliffs and talus slopes because of the resistant quartzites. Resistance to erosion by the Raval1i group is demonstrated by the high topography along E1k Divide. The contact between the Ravalli and the overlying Piegan group is conformable and gradational within a transitional zone of several hundred feet, wherein the siliceous sequences become dominantly carbonate rocks.

\section{Piegan Group}

Rocks of this group are named from the type locality found in Glacier National Park, where the group is characterized by its carbonate content. They are represented by the Wallace formation near Libby (14, p. 13), where extensive outcrops occur. The Wallace formation was named for outcrops in northern Idaho (33, p. 282).

The Wallace formation makes a conformable transition with eastward outcrops of the Piegan group along a zone approximately represented by the direction of Fisher River. Incomplete Wallace sections near the Kootenai River-Fisher River junction measure from 10,000 to 15,000 feet thick.

The Piegan group east of the Wallace-Piegan transition is divided into three units (25, p. 26), consisting of the lower $P_{1}$ unit, the middle Siyeh formation, and the upper $\mathrm{P}_{3}$ unit (fig. 3 ).

Lower Piegan

The basal member of the Piegan group was named the $\mathrm{P}_{1}$ unit from outcrops in the Ural area of northwest Montana. The $P_{I}$ unit was mapped in the Stryker area and southward along the east flank of the Salish Mountains, where its thickness ranges from about 2,500 to 3,500 feet. It crops out prominent1y in a zone of faulted blocks associated with the west side of the Rocky Mountain Trench.

\section{Siyeh Formation}

This formation was originally named for a type section found in Glacier National Park. In the tunnel area, the Siyeh formation is extensively exposed, although extensively faulted, along the northwest-trending east edge of the Salish Mountains. In the Stryker area and southward, from 4,500 to 5,000 feet of Siyeh rocks are exposed. The Siyeh formation is blocky to massive, thinto thick-bedded siliceous limestone with intercalated dolomite. The weathered color depends on the dolomite and pyrite content of the bed. Hall (17, p. 35) observed that pyrite was most extensively associated with massive calcite. Varigated banding makes some outcrops distinct. Local1y, low-dipping beds tend to form cliffs.

Upper Piegan

A rock unit assigned to the upper member of the Piegan group ( $P_{3}$ unit) is correlated with rocks lying to the east across the Rocky Mountain Trench. 


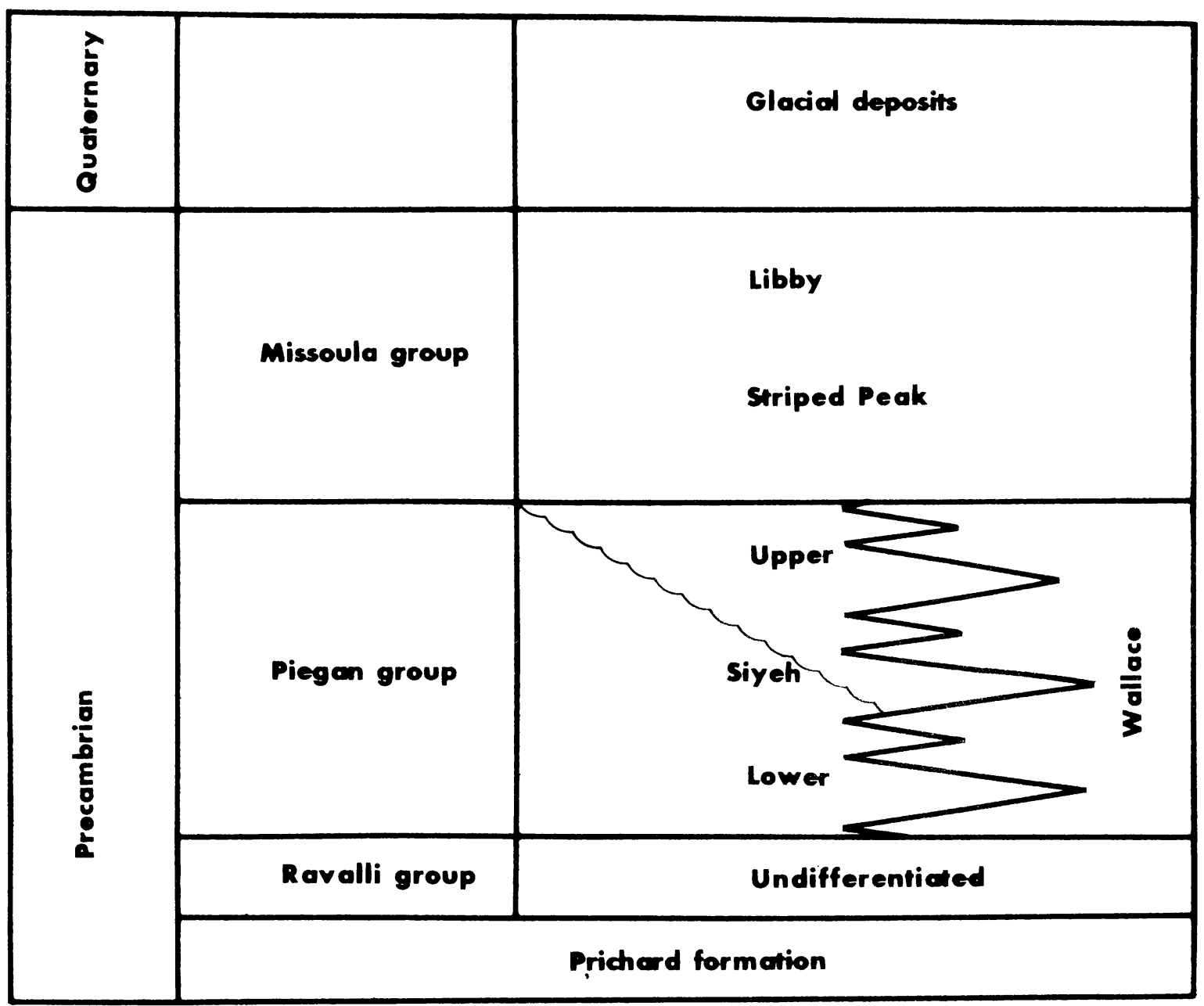

FIGURE 3. - Generalized stratigraphy of Salish Mountains.

These rocks are exposed only along the northern flank of the Salish Mountains near Rexford and Eureka; they apparently have been removed by erosion along the east flank of the Salish Mountains between Eureka and Kalispel1.

\section{Missoula Group}

The Missoula group was defined on the basis of Belt rocks further eastward in west-central Montana and includes all Belt rocks above the Piegan group. Equivalent rocks of the Missoula group are most closely stratigraphically equivalent with rock units to the west. In the central Salish Mountains, the Striped Peak and Libby formations make up the Missoula group.

Striped Peak Formation

The Striped Peak formation was named (34, p. 25) for crossbedded, ripplemarked, and mud-cracked shales and quartzites in the Coeur d'Alene region of Shoshone County, Idaho. A narrow segment of Striped Peak-type rocks, approximately paralleling the axis of a syncline, are found extending from the mouth of Fisher River southeastward to Wolf Creek. 
Libby Formation

The name Libby formation was applied (14, p. 17) to a rock sequence outcropping just above the Striped Peak formation in the Libby quandrange. Exposures are found west of the Flathead Tunnel along a northwest-southwesttrending syncline about 6 miles south of the junction of Fisher River and Wolf Creek.

The Libby formation is considered to be the upper part of the Belt Series in the locality, but the contact has been removed by erosion. It is conformable with the underlying Striped Peak formation. Its greatest thicknesses (5,000 to 7,600 feet) are probab1y southwest of Libby, but its absence has been noted in other areas.

\section{Igneous Rocks}

Within the surrounding area, a number of igneous bodies have been found $(25$, p. 53). Basic intrusives lie in western Lincoln County, while acidicrelated rocks are dominantly found in the vicinity of Libby. An apparent alinement of these intrusives is along a northeast trend. The granitic rocks are assigned an age corresponding to Cretaceous, based on geologic dating procedures. Igneous intrusives in the Salish Mountains appear structurally controlled. Hence their age is probably somewhat contemporary with, but later than, the folding.

Three metadiorite dikes outcrop about 18 miles southwest of the Flathead Tunne1 (sec. 14, T $28 \mathrm{~N}, \mathrm{R} 25 \mathrm{~W}$ ). The dikes strike east-west and cut Rava11i bedding at right angles. They lie on the crest of an anticlinal structure. A metadiorite dike striking northwest-southeast outcrops the Wallace formation near the junction of the Fisher and Kootenai Rivers. It lies on the axis of a synclinal structure. A similar dike was discovered during railroad grading a few miles up Fisher River and provided an excellent source of riprap and ballast for a portion of the line change

An alaskite stock about 1/3-square mile in surface area intrudes the Prichard formation and crops out in sec. 25 and $26, \mathrm{~T} 32 \mathrm{~N}, \mathrm{R} 29 \mathrm{~W}$, about 1 mile northeast of Warland. Several dikes, insufficient1y exposed to determine their orientation, radiate from this stock. This stock is at the east terminus of an east-west striking fault.

The presence of igneous float rock at several localities in townships surrounding the Flathead Tunnel suggest that possibly many more igneous bodies are present, but are concealed by shallow overburden. A concealed igneous body would be of concern to tunneling.

\section{Structural Geology}

Faulting

The Pinkham Thrust Fault $(\underline{25})$ is a medium- to high-angle, west-dipping fault having an upthrust west block (fig. 4). It was also named the Brush 
Pass Thrust by Hall in 1962 (17), and the E1k Mountain Fault by the Corps of Engineers in $1961(12,13)$. Surface mapping has traced the fault for a distance in excess of 70 miles, or throughout the length of the central Salish Mountains. The fault trends slightly northwest, paralleling Belt strata or truncating them at slight angles. At locations where the fault is surface exposed, it is found that Ravalli strata are missing.

At the extreme southern terminus, the Elk Mountain Fault divides into several radiating "horsetail" faults. Also to the south, the fault is contiguous with large-scale anticline-syncline structures, but is also known to cut the limbs of these folds. Drag folding, brecciation, silicification, shearing, fracture jointing, and cleavage are characteristic of rock adjacent to the fault zone. Noted also is that the E1k Mountain Fault has been displaced by several east-and northeast-striking transverse faults.

The fault crops out on the east flank of the Elk Mountain anticline and trends approximately $\mathrm{N} 20^{\circ}-30^{\circ} \mathrm{W}$. On the surface, it appears to be a mediumto high-angle fault, but in the subsurface intersection with the tunnel (to be discussed later) it has a dip of about $30^{\circ}$ and displacement of several hundred feet.

The name Dunsire Thrust was given by Hall (17, p. 42) to a fault nearly paralle1 to the E1k Mountain Fault, but lying about 2 miles east and following Dunsire Creek. The fault apparently terminates near Fortine Creek after faulting Siyeh rocks for more than 30 miles. The Dunsire Thrust is of much smaller magnitude than the E1k Mountain Fault and has an estimated displacement of between 500 and 1,000 feet in the vicinity east of E1k Mountain.

Siyeh rocks west of the fault dip vertically, while Siyeh rocks east of the fault are near horizontal. Other faults also parallel the Elk Mountain Fault in the same relative location as the Dunsire Thrust throughout the area, but these cannot be mapped as continuously.

The Stryker Fault was named by Gilmour (16) for a large-scale fault easily seen on aerial photographs in the vicinity of the east shore of stryker Lake. This fault is believed to be an extension of the west edge of the Rocky Mountain Trench; as such an extension, the fault can be traced (mostly in glacial deposits) for many miles in the Stillwater Valley. Stratigraphic displacement between Ravalli rocks on the east and lower Piegan on the west is estimated as about 4,000 feet. Fault displacement decreases to the northwest. Strike of the fault trends about $\mathrm{N} 35^{\circ} \mathrm{W}$.

Another type of major faulting is the east-west type. One of the 1 argest of these east-striking transverse faults is mapped along Warland Creek (and extending west across the Kootenai River) for a distance of about 25 miles. Movement on this fault is believed vertical with the north side downthrown with respect to the south side. The fault displaces fold axes, rock contacts, and north-south faults. However, if this fault is projected eastward another township, it is found in the same vicinity as the Gray Creek Fault; but an exact location is obscured by the east branch of the Elk Mountain Fault (the Twin Meadows and Gray Creek Faults are discussed 1ater). On the same 
reasoning, if we project possible faults for Cripple Horse Creek-Good Creek and for Five Mile Creek-Basin Creek across the tunnel profile, it is seen that these projected east-west faults were indeed intersected in the tunnel at their projected locations. Twin Meadows Fault can be projected from Five Mile Creek.

Another major east-west fault found about 2 miles south of the south portal was named the E1k Divide Fault for its intersection with that topographic feature. It is inferred on the basis of outcrop evidence to be a nearly vertical fault that strikes about $\mathrm{N} 85^{\circ} \mathrm{W}$. Near Wolf Creek, and to the west, it becomes indistinct when crossing the axes of two folds, and it may continue into Canyon Creek. The Elk Divide Fault does, however, have a traceable length to the east of about 15 miles. This fault, like others, appears to be downthrown on the north side.

Several other east-striking faults are known in the region and in the tunnel site area, but few of these have either been mapped or named (fig. 4). Little direct surface evidence of east-west faulting can be observed. Most faults are covered by topsoil and are mapped by relative displaced contacts, topographic expression, changes in drainage patterns, and alinement of springs. It can reasonably be assumed that all east-west drainage is fault controlled. Aerial photographs also aid in delineating faults. However, many mapped faults are inferred without positive confirmation of their presence. Many faults are contiguous with the crests of anticlines and the troughs of synclines and cannot be discussed without reference to the other. Faults with displacements of several thousand feet are the most spectacular of the geologic structures, but were the most difficult to adequately delineate underground.

\section{Folding}

Throughout the Salish Mountains and the surrounding region, numerous symmetrical trending anticline-syncline patterns are found (fig. 4). These structures are of various types ranging from tight to broad symmetrical, asymmetrical, and some overturned structures. Most often the east limb of the anticline is overturned. Commonly the limb of one anticline becomes the flank of another parallel syncline. The axial plane of folds generally parallels the north to northwest strike of Belt strata. Structural depth of the folds ranges from 1 to 4 miles with axial lengths of a few miles to many tens of miles. Distances between crests of anticlines and troughs of synclines range from 1 to 10 miles. Local drainage patterns have given the appearance of breached anticlines to several of these structures.

With respect to the tunnel site locality, three anticline-syncline structures are of particular interest. The E1k Mountain anticline is a double-plunging asymmetrical structure named for its contiguous proximity to E1k Mountain. This anticline is a mappable structure for a distance of nearly

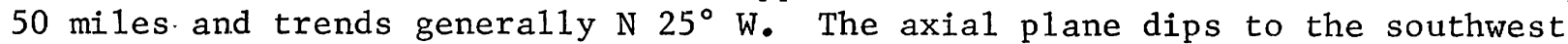
at shallow to locally steep angles with overturning prevalent toward the northeast. The overturned east 1 imb dips as much as $70^{\circ}$. At severa1 1 ocalities, the anticline is displaced by longitudinal and transverse faults, 
particularly in the central part of the E1k Divide Fault. The anticline is expressed in Rava11i rocks near E1k Mountain with exposures of Prichard rocks on the overturned and faulted east flank.

The west flank of the Elk Mountain anticline becomes the east flank of the slightly asymmetrical Wolf Creek syncline. These two structues have common parallel flanks for a distance of about 25 miles. East flank dips of the syncline average $10^{\circ}$ to $20^{\circ}$, and west flank dips average slightly higher than $20^{\circ}$. Upper Wolf Creek drainage has locally downcut through the syncline and partially into the Elk Creek anticline in the vicinity of the south portal.

The east flank of the E1k Mountain anticline becomes the west flank of the Ingalls syncline (named for Ingalls Mountain) and parallels the E1k Mountain anticline, where it can be traced for nearly 30 miles. Flank dips of this structure average $10^{\circ}$ to $20^{\circ}$. Surface rocks of this syncline are a11 Piegan. Numerous faults cut the syncline also. Farther east of the Ingalls syncline are a series of relatively symmetrical anticline-syncline structures (less than 10 miles long and a few miles across). More such structures are shown on figure 4 .

\section{Jointing}

Orientation of rock jointing was, of course, expected to be of great influence on construction of the tunnel. A well-developed joint system was recognized by all who had examined the tunnel route. The jointing system was made up of the following components: bedding joints, which either were low angle or near vertical; bedding plane joints complementary with the bedding strike but dipping normal to the bedding; a joint set striking in an eastwest direction between $\mathrm{N} 50^{\circ} \mathrm{E}$ and $\mathrm{S} 70^{\circ} \mathrm{E}$ and dipping from $75^{\circ}$ to vertical; and a joint set that strikes from $\mathrm{N} 30^{\circ} \mathrm{W}$ to $\mathrm{N} 20^{\circ} \mathrm{E}$, and dips at moderate to high angles.

As a broad generalization, the more flat lying or gently dipping beds with pronounced north-south and east-west jointing are found in the south portal portion of the tunnel. With this jointing, the tendency was for over break in the corners of the tunnel arch, producing a more square section. Associated with the north portal are closely-spaced bedding joints dipping $70^{\circ}$ to vertical and striking $\mathrm{N} 20^{\circ} \mathrm{W}$, in combination with east-west joints. These joint sets, together with small faults, created a jagged (saw-blade) appearance along the walls of the tunnel with some overbreak and instability on the tunnel ribs, especially the west rib. This effect was somewhat aggravated by the fact that much of the rock penetrated is in the Ravalli, where great contrasts in rock competency are present between the interbedded quartzites and argilites.

The relationship of joint strike to tunnel alinement was of critical importance to overbreak in the tunnel section. Generally, where the angle was less than $15^{\circ}$, overbreak occurred and usually followed the joint plane. In order of importance, bedding joints were most influencial followed by east-west and north-south joints, respectively. 
Gilmour (16, p. 54), Hall (17, p. 48), and the Corps of Engineers (12) surface mapped two dominant joint sets in Belt strata in the area surrounding the tunne1. The most prominent set strikes very nearly east-west and dips vertically plus or minus $20^{\circ}$. A less prominent set trends about perpendicular to the major set with a strike of about $\mathrm{N} 20^{\circ} \mathrm{W}$ to $\mathrm{N} 20^{\circ} \mathrm{E}$ and dip of $70^{\circ}$ to $90^{\circ}$. Quartz veins over 1 foot thick commonly occur along these joints. Hall (17, p. 48) also noted a fracture cleavage feature that is present only along the east flank of E1k Mountain anticline. This type of fracture cleavage appears localized on the steeper limb, apparently as a result of relatively more intense shearing of one bed past another as a result of folding. The cleavage strike is closely parallel to the axis of the anticline and dips at $45^{\circ}$ to $65^{\circ}$ to the west. Fracture cleavage is characteristically more prevalent in argillite beds located between more competent quartzites.

\section{Tunnel Geology}

\section{Station 3003 to Station 3081 (7,800 feet)}

This section begins at the north rock portal and continues southward to Davis Creek. Rock cover for this section ranged from 80 to 140 feet. The very shallowest overburden was found by feeler hole during excavation near exploratory hole 375 (approximately station $3029+80$ ) to be about 14 feet of solid rock cover (fig. 5).

Rock penetrated in this segment was upper and middle Ravalli. It is here classified as better than average competent rock composed of hard, argillitic quartzite with interbedded, moderately hard to soft argillite beds. Bedding thicknesses range from less than an inch for argillites to several feet for quartzites. Bedding strikes $\mathrm{N} 25^{\circ}$ to $30^{\circ} \mathrm{W}$ and dips vertically to about $75^{\circ} \mathrm{W}$. Three strong joint sets exist. One set strikes east-west with dips of $45^{\circ}$ to vertical. A second set has a similar dip, but strikes approximately north-south. The third set is subhorizontal. Nearvertical dips were predominantly found during tunnel driving. We11 tests in the exploratory holes indicated low transmissibility; hence, 1ittle water seepage was expected. No significant water inflows occurred during excavation.

\section{Station 3081 to Station 3106 (2,500 feet)}

This segment lies between Davis Creek and where Fortine Creek intersects the tunnel alinement. Rock cover is between 100 and 200 feet. Ground water inflow was expected to be about the same as the previous section, but an unexpected water-bearing fault zone near either creek could be significant if intersected. Surface drainage helped eliminate surface ground water inflow and, fortuitously, no water-bearing zones were encountered during excavation.

Throughout this segment of tunnel, rock encountered was considered mainly softer and argillitic in composition with interbedded, moderately hard argillites and some very hard quartzite beds. These rocks strike $\mathrm{N} 20^{\circ}$ to $25^{\circ} \mathrm{W}$ and dip $75^{\circ} \mathrm{W}$. The main jointing sets are closely spaced and high angle, from $60^{\circ}$ to $90^{\circ}$. 


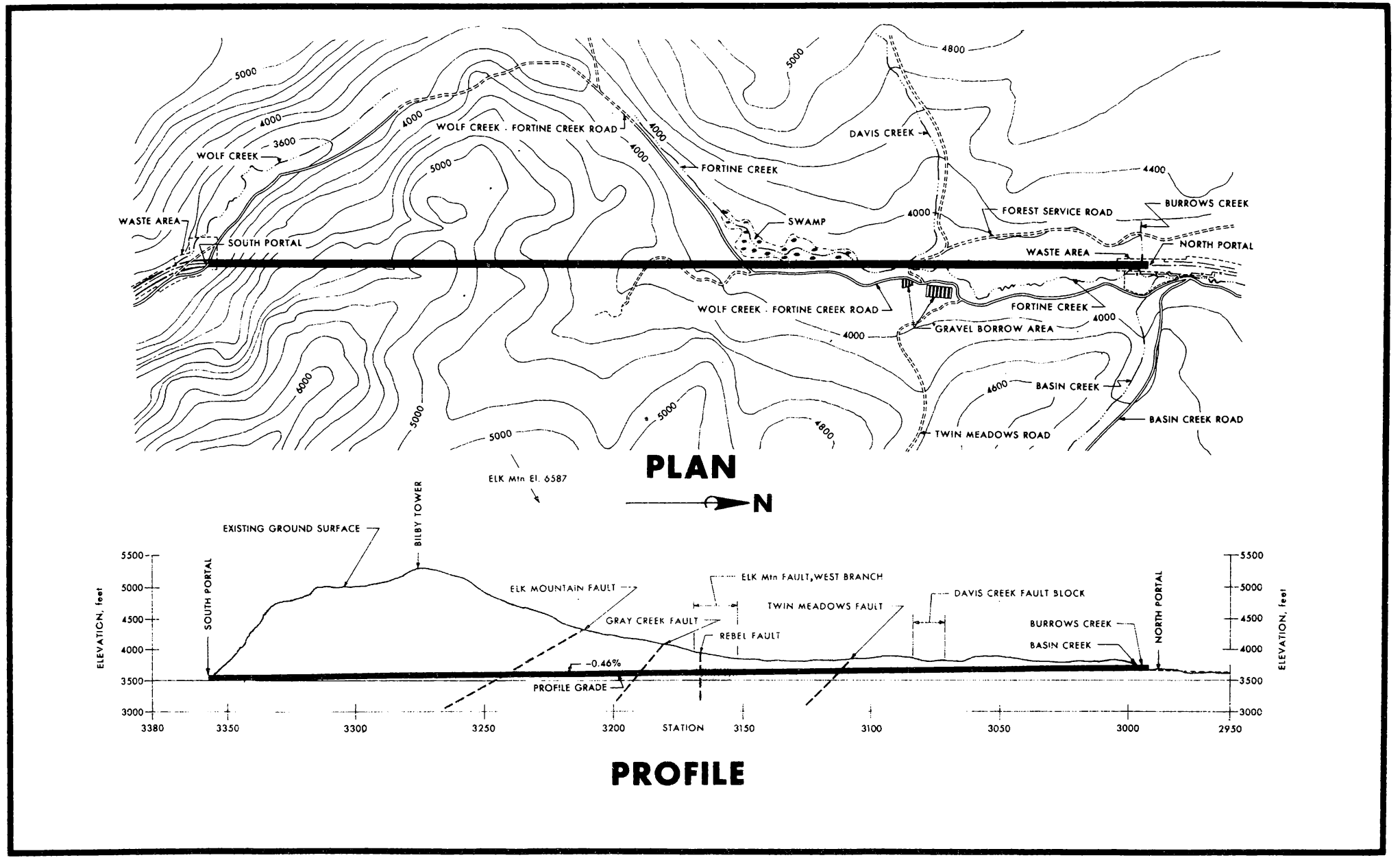

FIGURE 5. - Flathead Tunnel profile. 
This section of tunnel is extensively covered by overburden, which severely hampered an adequate surface geologic investigation. Between station 3106 and station 3228 (where rock crops out on the northern ridge of E1k Mountain) there are almost no outcrops, and geologic data had to be projected onto the tunnel route. The section is a swampy, basinlike terrace in the upper headwaters of Fortine Creek. Most of the overburden was watersaturated material ranging from clays to gravels and glacial debris.

About 25 percent of the drilling exploration effort was expended in this section. The deepest topsoil over burden was determined to be about 75 feet, and the minimum rock cover about 100 feet. At the rock outcrops on the flank of E1k Mountain, 1,270 feet of rock overlies the tunnel.

Although the shallowness of rock overburden, along with an overlying water-saturated topsoil, made this a potentially dangerous zone before construction, it was the presence of at least three known faults that could not be effectively delineated that caused this segment to be of most concern. The meandering drainage of Fortine Creek and its tributaries in the swampy, saturated topsoil was expected to produce the largest ground water inflows along the entire tunnel route. The four faults--Twin Meadows, west branch of E1k Mountain, Rebe1, and the Gray Creek--are all found within this segment of tunnel. They are each described in detail in the following section on faults. The largest ground water inflow occurred in crossing Gray Creek Fault and is described in the section on ground water.

\section{Station 3228 to Station $3356(12,800$ Feet)}

This segment of tunnel begins on the northern shoulder of E1k Mountain at about the point where the Elk Mountain Fault crops out and continuous bedrock is exposed southward to the south portal on Wolf Creek. Rock units along this section are lower Raval1i to upper Prichard, moderately hard argillitic to quartzitic in composition. Bedding dips on the outcrop range from horizontal to about $20^{\circ}$ northwest. Along the tunnel route, bedding was most1y near horizontal.

The E1k Mountain Fault was penetrated at about station 3242. More complete details on this fault will be discussed in following sections of this report. Another high-angle, east-west fault was observed on the surface at about station 3302, but was encountered underground as a 200-foot-wide swarm of minor faults and sheared rock at a depth of about 1,500 feet. No difficulty in tunneling occurred in this fault.

This section of tunnel also passed under the point of maximum rock overburden of about 1,700 feet near station 3275. No significant ground water was expected, because of the rather steep open topography through this section of tunnel. Little or not ground water occurred during construction. 
$\underline{\text { Fault Descriptions }}$

Faults

From the previous geology discussion, it is evident that major geologic structural changes occurred along the tunnel route. These features were of great concern during exploratory mapping and of even greater concern during tunnel driving. Of course, not all faults can be discussed, but the following six are considered most important. Two basic types of faults were recognized. Faults striking about $\mathrm{N} 10^{\circ} \mathrm{W}$, and that are high angle, have characteristics of thrust faulting. The tunnel route is nearly parallel with these faults and caused the most difficulties during tunnel driving. The second fault type strikes east-west with nearly vertical dip. One of these faults, in conjunction with other factors, caused difficulty in portal construction.

\section{E1k Mountain Fault}

This is the most significant fault along the entire tunnel route. It is structurally combined with the Elk Mountain anticline and appears to have been partially truncated to the east by the Gray Creek Fault (near the midpoint of the tunnel at station 3191) and offset to the east, requiring two crossings by the tunnel. The first fault penetration was centered about station 3243, with about 1,000 feet of rock cover, and was encountered essential1y as predicted. During crossing by the tunnel, the fault exhibited drag folding on the hanging wall (west) side and contained 30 to 45 feet of fault gouge along with detached masses of highly fractured rock. The fault zone is bounded by fault planes with additional secondary faults recognized within the fault gouge. These local faults had dips ranging from $30^{\circ}$ to $70^{\circ}$. The only instance of support troubles occurred in crossing the hanging wall portion of the fault and this will be discussed in the section on ground support, special problems (tunne1).

The second crossing of the E1k Mountain Fault zone occurred between stations 3152 and 3168 (about 1,600 feet). This offset portion of the E1k Mountain fault was found as a low-angle fault and, because of the converging intersection between the fault and tunnel alinement, a great distance of tunnel was required to penetrate through the fault zone. Little surface expression could be mapped because of the mantle of topsoil. Rock cover ranged from less than 200 feet to about 500 feet. Experience gained in passing through the previous portion of the E1k Mountain Fault helped in minimizing ground support problems. The entire fault zone was supported by 8 -inch sets on 1.5 - to 4-foot centers, solidly lagged, with nearly all invert struts placed across the fault zones.

\section{Rebel Fault Zone}

This fault zone was named during active construction for a faulted section of greater than expected magnitude that occurred within the second crossing of the E1k Mountain Fault. Between stations $3165+79$ and $3165+23$, a section of very wet, highly fractured and sheared rock, accompanied by gouge 
and fault breccia, and possibly hydrothermally altered, was encountered. Remnants of apparent sheared folds and change in bedding attitude suggest an origin more complicated than the remainder of the E1k Mountain Fault. The zone was assumed to have a strike and dip similar to the E1k Mountain Fault of about $\mathrm{N} 15^{\circ}-20^{\circ} \mathrm{W}$ and $20^{\circ}$ to $30^{\circ}$ west dip, but local zones are near vertical to overturned where sheared. This zone was carried entirely by 8 -inch sets with invert struts, and lagged solidly throughout its length.

Gray Creek Fault

The relationship of the Gray Creek Fault to the E1k Mountain Fault was discussed previously. The Gray Creek Fault is a southwest-northeast-striking fault and dips about $30^{\circ}$ to the southeast. Upon penetration by tunneling, it consisted of a simple 3-foot-thick gouge-filled zone. It did, however, temporarily produce the most water, as further discussed in the section on ground water. No difficulty in tunnel driving was experienced. The presence of this fault was suspected by an apparent offset in the E1k Mountain Fault and by certain topographic evidence. Rock overburden at the crossing of the fault was about 500 feet.

\section{Twin Meadows Fault}

This fault was originally detected from surface mapping and drilling. These data suggested a shear zone about 120 feet wide adjacent to a fault striking east-west and dipping about $55^{\circ}$ south. Actual tunnel driving found about 200 feet of continuous gouge and shattered rock, consisting of a series of east-west - and northwest-striking faults with variable dip $25^{\circ}$ to $40^{\circ}$ north to $60^{\circ}$ to $85^{\circ}$ south. This zone was between stations 3112 and 3114 , approximately. Large, but variable, amounts of fault gouge along with fractured blocks of intact rock were also found in the main fault zone. On either side of the main fault, for a few hundred feet, bedding faults have a nearvertical dip, strike $\mathrm{N} 20^{\circ} \mathrm{W}$, and are well developed and common. This fault zone was easy to excavate, often requiring little blasting. Continuous support for 350 feet of 8-inch invert strut sets on 18-inch to 3-foot centers and solidly lagged was used in the Twin Meadows Fault.

Although 1ittle difficulty was actually experienced through this fault zone, it had been expected to be troublesome from the exploration data. The combination of tunnel alinement, fault orientation, and Fortine Creek crossing the route created a potentially hazardous situation. Also, rock overburden was estimated as a maximum of only about 100 feet. Another 50 feet of topsoil above the rock was water saturated.

\section{Davis Creek Fault Block}

A geologic feature of large extent that was not predicted by any exploration effort was encountered in the vicinity of Davis Creek. Approximately 
between stations 3070 and 3083 (1,300 feet) an intact block of sediments has been sharply faulted and displaced into a near-horizontal position. Other faults and sharp folds encountered before and after this section suggest a very complicated origin for this fault block. Thick surface topsoil (without outcrops) concealed this structure. No ground support problems were encountered through this section.

\section{Basin Creek Fau1t}

The complete extent of this fault was not determined. It is, however, a high-angle, east-west-striking fault closely associated with Burrow's Creek at at the north portal. Difficulties here are discussed in the section on ground support, special problems (portal).

\section{EXCAVATION PROGRAM}

\section{Preparation Period}

Exploration

A number of railroad routes were initially studied. Between 1948 and 1954, the selection was narrowed to five railroad routes. An outside consultant was also engaged for route studies in 1953. Successive routes were discarded for various reasons after studies showed an individual route to be significantly less desirable than an alternative route. Discarded routes all involved either longer mileage or longer tunnels. Other routes examined required tunnel lengths ranging from 5.8 to 12 miles. Route selection terminated in July 1961, with the present route receiving further study beginning in February 1961 and continuing until construction began. The 7mile Flathead Tunnel route was developed in the search for an optimum alinement, which would present a minimum of construction problems and be acceptable in terms of grades, curvature, and maintenance.

More detailed reconnaissance, surface geologic mapping, and subsurface exploration programs were begun in the fal1 of 1961. This was accompanied by stratigraphic and structural geology studies during most of 1962. Field mapping was transferred to aerial photographs, an aerial magnetic survey was completed, 5 and a contract drilling program was begun which was completed during the 1963 field season. Geologic surface mapping, to a scale of 1 inch equals 200 feet, was completed along the tunnel alinement in 1963. Drilling was resumed during 1965 in the Burrows Creek and portal areas. Table 1 lists a11 31 drill holes completed for purposes of tunnel exploration.

\footnotetext{
${ }^{5}$ This was the only major geophysical work. Results indicated no apparent definable concealed igneous intrusives along the tunnel route. This was confirmed during tunneling. A seismic refraction survey was run at the north porta1 near Burrow's Creek.
} 
TABLE 1.- Dri11 holes for tunne1 exploration ${ }^{1}$

\begin{tabular}{|c|c|c|c|c|}
\hline Hole number & Depth, feet & $\begin{array}{c}\text { Core recovery, } \\
\text { percent }\end{array}$ & Approximate station & Date drilled \\
\hline 322 & 33.0 & 99 & $2998+20$ & 1962 \\
\hline 323 & 71.5 & 100 & $2994+50$ & 1962 \\
\hline 324 & 64.6 & 65 & $2995+50$ & 1962 \\
\hline 325 & 30.1 & 100 & $2992+90$ & 1962 \\
\hline 326 & 35.4 & 100 & $2991+19$ & 1962 \\
\hline 327 & 32.0 & 100 & $3001+80$ & 1962 \\
\hline 328 & 95.5 & 100 & $2994+95$ & 1963 \\
\hline 329 & 94.4 & 100 & $2995+71$ & 1963 \\
\hline 330 & 70.9 & 99.3 & $2997+75$ & 1963 \\
\hline 332 & 111.0 & 100 & $3355+95$ & 1963 \\
\hline 333 & 195.6 & 86 & $3111+30$ & 1963 \\
\hline 334 & 265.3 & 92.4 & $3151+00$ & 1965 \\
\hline 335 & 439.2 & 99.3 & $3175+20$ & 1963 \\
\hline 336 & 498.8 & 98 & $3202+00$ & 1963 \\
\hline 337 & 217.0 & 100 & $3127+00$ & 1963 \\
\hline 366 & 81.0 & $\left({ }^{2}\right)$ & $3359+00$ & 1965 \\
\hline 367 & 46.0 & $\left({ }^{2}\right)$ & $3357+30$ & 1965 \\
\hline 368 & 83.4 & (a) & $2987+90$ & 1965 \\
\hline 369 & 82.2 & (a) & $2988+70$ & 1965 \\
\hline 370 & 78.7 & (a) & $2988+80$ & 1965 \\
\hline 371 & 43.0 & (a) & $2989+59$ & 1965 \\
\hline 372 & 200.0 & 98 & $3118+75$ & 1965 \\
\hline 373 & 200.2 & 88.5 & $3108+80$ & 1965 \\
\hline 374 & 162.8 & 79 & $3087+85$ & 1965 \\
\hline 375 & 130.1 & 99 & $3029+80$ & 1965 \\
\hline 376 & 180.2 & 97 & $3071+10$ & 1965 \\
\hline 384 & 149.8 & 95.5 & $3035+75$ & 1965 \\
\hline 385 & 139.7 & 91 & $3022+80$ & 1965 \\
\hline 386 & 234.9 & 88 & $3111+85$ & 1965 \\
\hline 624 & 33.0 & 100 & $3357+50$ & 1962 \\
\hline 626 & 108.0 & $(2)$ & $3360+10$ & 1962 \\
\hline
\end{tabular}

Total of 31 holes; total foctage $4,207.3$ feet.

2Not cored.

\section{Route Surveying}

Preconstruction route alinement consisted of double theodolite surveys carried from monuments and a standard 37 -foot Bilby tower, maintained on the centerline, between portals at station $3274+92$. The Bilby tower was visible from both portal monuments. This alinement survey was independently run by the Corps of Engineers, the contractor, and a contract surveying company. Centerline was carried into the tunnel, where permanent points (steel pins) were set at approximately 1,000-foot intervals. From these points, 1ine and grade were set along each rib. Construction control at the headings was done from these line and grade points with laser surveying instruments (to be discussed in the alinement control section). At "hole through," the horizontal closure error was 0.46 foot, and vertical closure was 0.07 foot. 


\section{Portal Excavation}

Total tunnel length includes cut-and-cover portal sections of 305 feet at the south portal and 1,365 feet at the north portal. The ventilation system constitutes about 300 feet of the north portal section and is included in the total north portal length. All portal sections of cut-and-cover construction amount to 5.2 percent of the total tunnel length.

Exploration at the south portal consisted of five drill holes totaling 379 feet. Hole depths ranged from 38 to 111 feet. Exploration at the north portal consisted of 13 holes, totaling about 815 feet. Hole depths ranged from 32 to 95.5 feet. Nearly al1 exploratory drilling was within 200 feet of the centerline. At the north portal, five holes were drilled directly along tunnel centerline, and at the south portal, three holes were drilled along centerline. Portal drilling accounted for only about 28 percent of the total exploration footage. However, 58 percent of the total number of drill holes were at the portals. Further details of these drill holes were shown in table 1 ; portal drill holes are tabulated in table 2 .

TABLE 2. - Exploratory portal dril1 holes

$$
\text { Dri11 hole number } \quad \text { Depth, feet }
$$

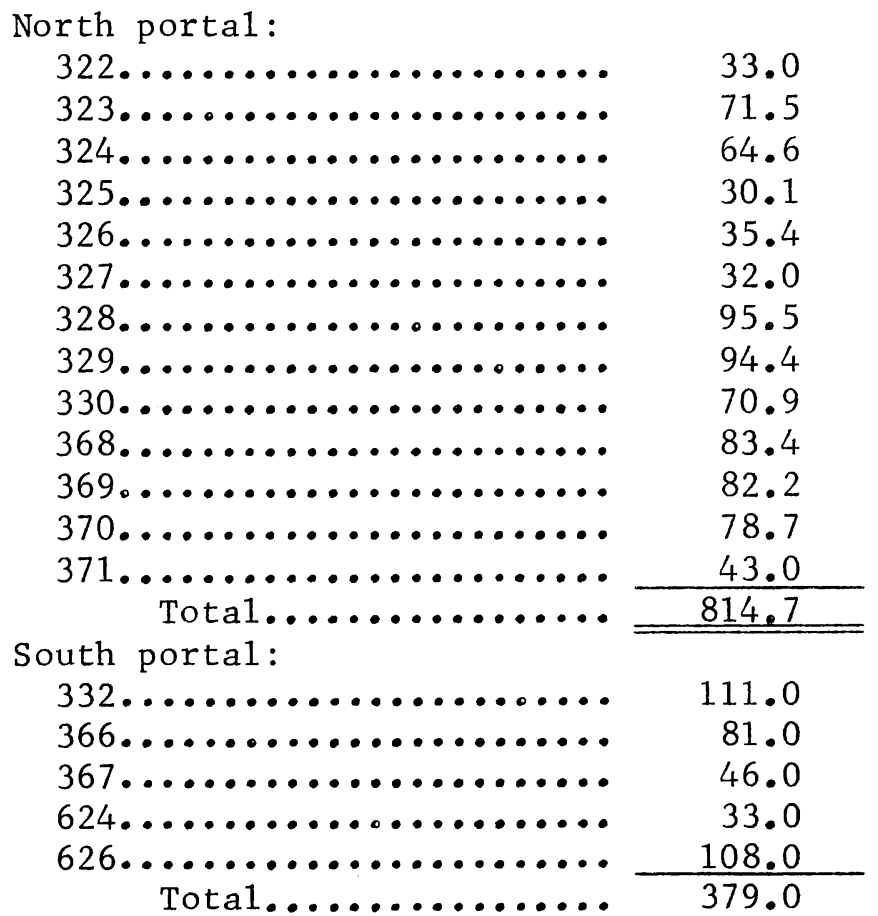

The north portal cut reached a maximum depth of about 110 feet before the rock portal was begun. Rock walls were carried on 1:4 slopes with 10-foot berms at the top of the rock. Some difficulty was experienced with earth cuts at the north portal, and this will be discussed in a later section on special problems (porta1). The depth of excavation versus direct tunnel driving was 
economically analyzed, and the results showed that tunneling would be more economical for overburden depths exceeding 70 to 90 feet.

The south portal was similar in excavation to the north portal, with $1: 4$ slopes and 10-foot berms. Maximum excavated depth to the beginning of underground tunneling was also about 110 feet at the south portal. No difficulties were encountered at the south portal. Figure $6 \mathrm{~A}$ is a cross section of the north portal, $6 \underline{B}$ of the south portal. Total exiavation at the south portal was about 26,000 cubic yards of soil and 10,000 cubic yards of rock. Correspondingly, the north portal required about 194,000 cubic yards of earth

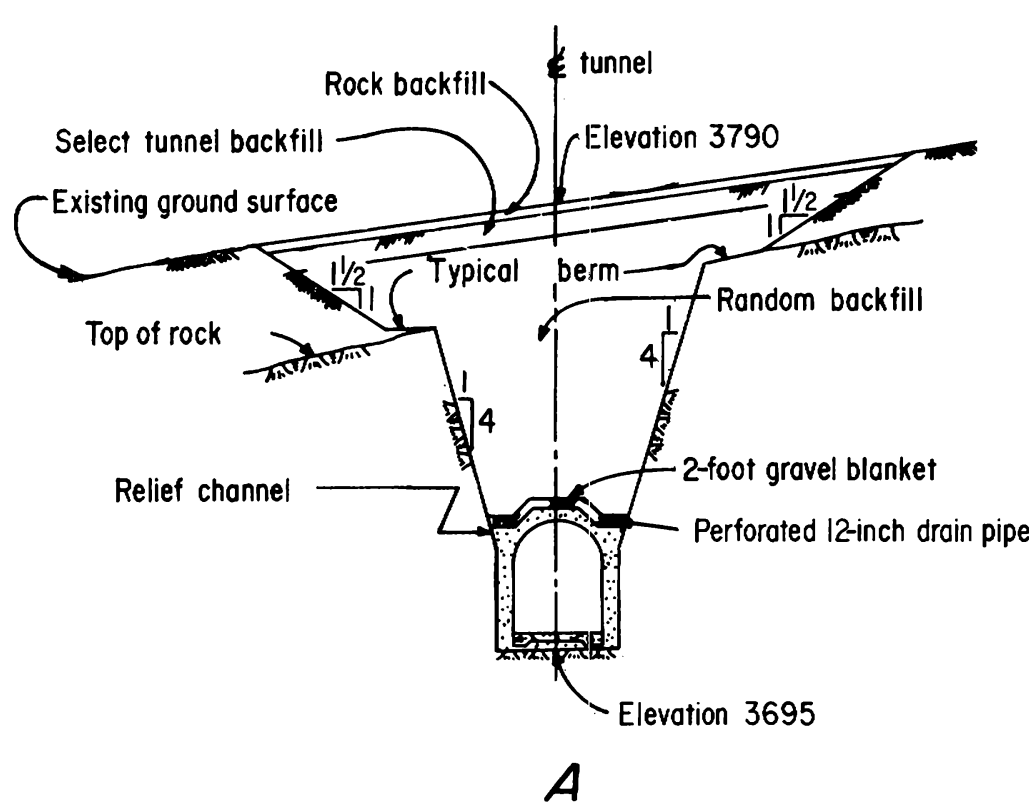
excavation and 72,000 cubic yards of rock excavation. A11 material, however, was used for the surface site fill.

\section{Surface Facilities}

Essentia11y dup1icate facilities were necessary at each portal, except for the main forward area construction offices, which were maintained at the north portal area.

Figure 7 shows the typical surface plant layout at the north portal. These facilities included an extensive machine shop for the repair and maintenance of equip-

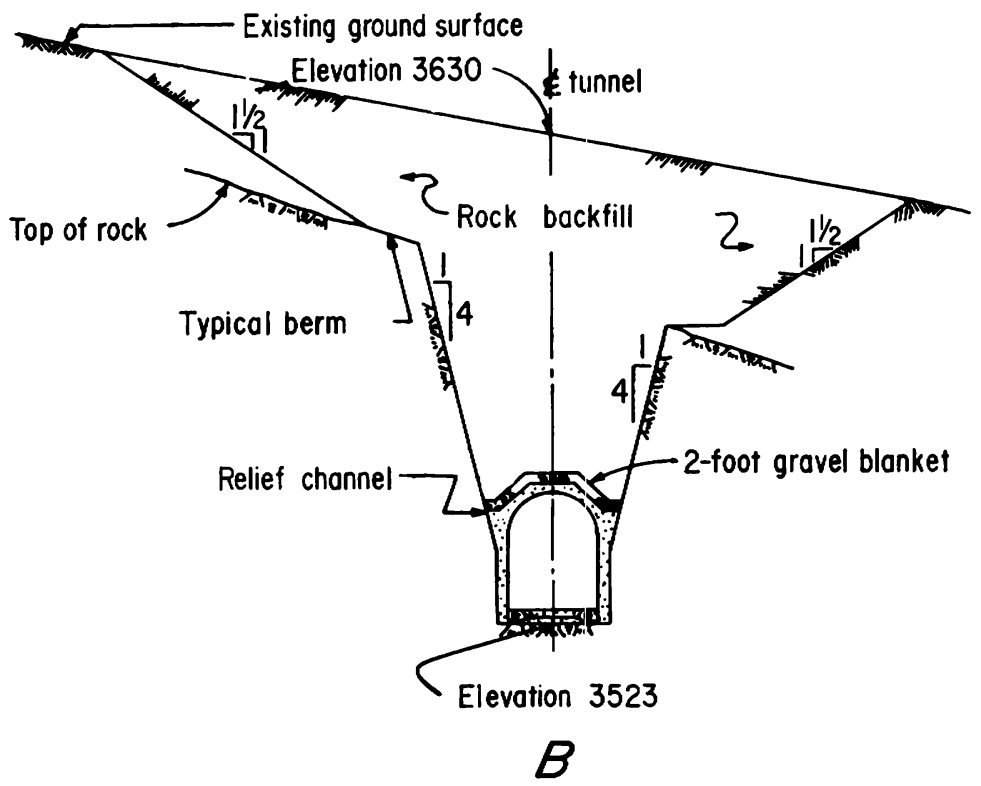

FIGURE 6. - Cross sections of portal excavation. ment, including a partssupply warehouse. A similar shop handled electrical equipment. A carpenter shop was also maintained. Other facilities were a changehouse and first-aid station. Not shown on the figure is a powder magazine, which was erected at a recommended safe distance offsite and entirely enclosed by a rock-filled timber crib, and which met all safety requirements. The south portal had a similar surface plant, except for offices and winterizing of concrete facilities. About 


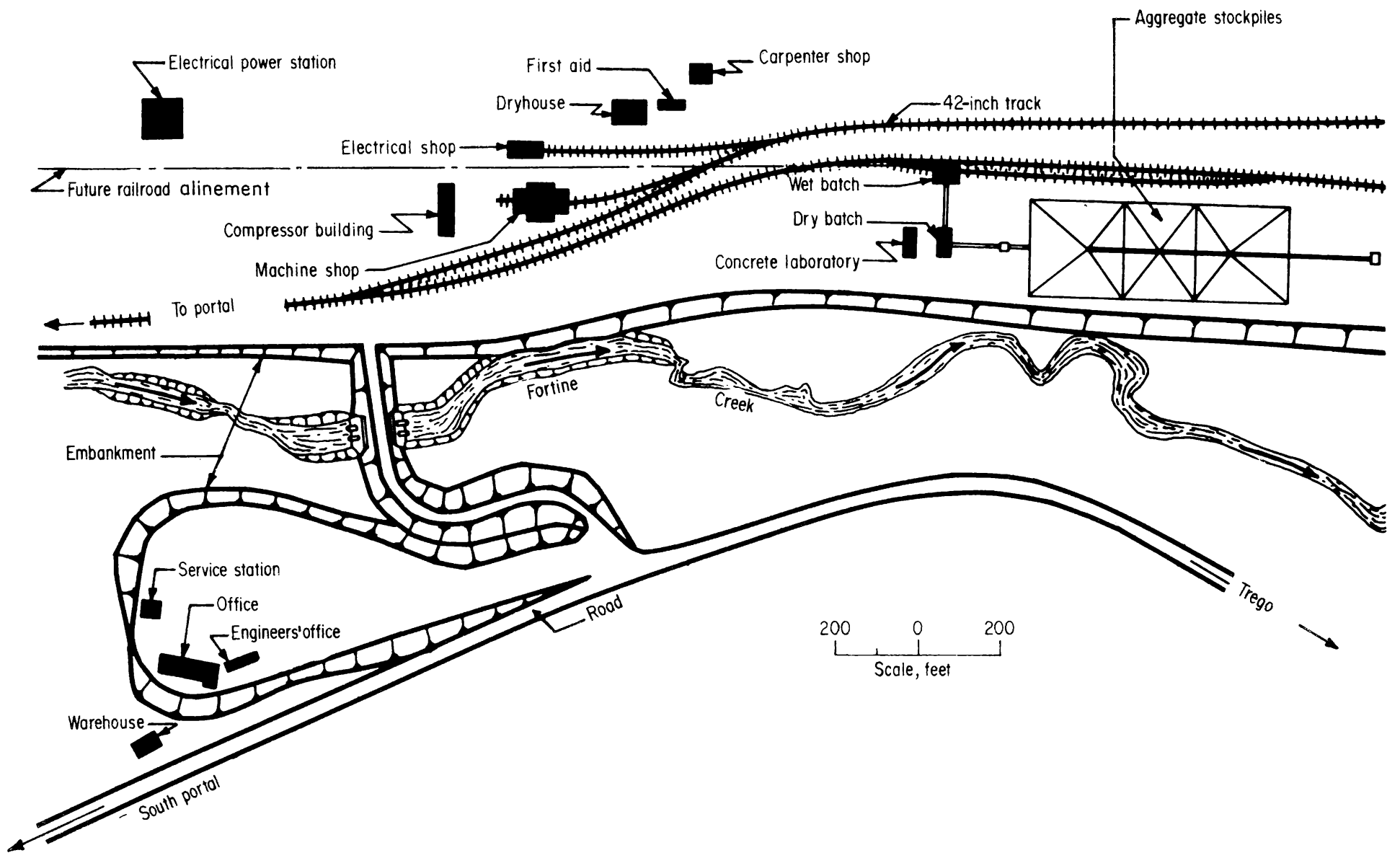

FIGURE 7. - North portal plant layout. 
143.75 acres of clearing and 517,500 cubic yards of embankment fill and/or excavation were required for the surface sites. This work was subcontracted. A11 of this material was used to level the portal plant sites and to bring the sites up to railroad subgrade. Surface facilities at both sites were within about 1,000 feet of the portals.

\section{I'unne1 Driving Progress}

South Heading

The first round was fired in the south heading at 3:00 p.m., September 30, 1966. Excavation was subsequent1y continued for 19,907 1inear feet of tunne1, requiring 1,425 shifts and 3,866 rounds for completion from this heading. The south heading was operated 10 days longer than the north heading in order to drive an additional 193 feet of tunnel for the "hole-through" ceremony, to be described 1 ater in the explosives and blasting section. Table 3 1ists month1y progress from the south heading.

TABLE 3. - Tunnel driving progress, south heading

\begin{tabular}{|c|c|c|}
\hline Reporting period & $\begin{array}{l}\text { Reporting period } \\
\text { progress, feet }\end{array}$ & $\begin{array}{c}\text { Cumulative progress, } \\
\text { feet }\end{array}$ \\
\hline Sept. 30,1966 -Nov. 1, 1966...... & 635 & 635 \\
\hline Nov. $1,1966-$ Dec. $1,1966 \ldots \ldots \ldots \ldots$ & 851 & 1,486 \\
\hline Dec. $1,1966-$ Dec. $24,1966^{1} \ldots \ldots \ldots$ & 758 & 2,244 \\
\hline Jan. 4, 1967-Feb. 1, 1967........ & 675 & 2,919 \\
\hline Feb. 1, 1967-Mar. 1, 1967_....... & 964 & 3,883 \\
\hline Mar. 1, 1967-Apr. 1, 1967........ & 1,278 & 5,161 \\
\hline Apr. 1, 1967-May 1, 1967......... & 1,076 & 6,237 \\
\hline May 1,1967 -June $1,1967 \ldots \ldots \ldots \ldots$ & 1,098 & 7,335 \\
\hline June 1, 1967- July 1, 1967_...... & 1,201 & 8,536 \\
\hline July 1,1967 -Aug. $1,1967 \ldots \ldots \ldots \ldots$ & 1,022 & 9,558 \\
\hline Aug. 1, 1967-Sept. 1, 1967........ & 1,312 & 10,870 \\
\hline Sept. 1,1967 -Oct. $1,1967 \ldots \ldots \ldots$ & 756 & 11,626 \\
\hline Oct. $1,1967-$ Nov $.1,1967 \ldots \ldots \ldots$ & 1,222 & 12,848 \\
\hline Nov. $1,1967-$ Dec. $1,1967 \ldots \ldots \ldots \ldots$ & 1,300 & 14,148 \\
\hline Dec. 1, 1967-Dec. 24, 1967_...... & 1,043 & 15,191 \\
\hline Jan. 3, 1968-Feb. 1, 1968........ & 1,232 & 16,423 \\
\hline Feb. 1, 1968-Mar. 1, 1968........ & 844 & 17,267 \\
\hline Mar. $1,1968-A p r .1 .1968 \ldots \ldots \ldots \ldots$ & 1,210 & 18,477 \\
\hline Apr. 1, 1968-May 1, 1968......... & 581 & 19,058 \\
\hline May 1, 1968-June 1, 1968......... & 474 & 19,532 \\
\hline June 1,1968 -June $21,1968^{2} \ldots \ldots \ldots$ & 375 & 19,907 \\
\hline
\end{tabular}

IVoluntary shutdown for holiday.

2June 21, 1968: "hole-through day."

Peak daily advances from the south heading were recorded on December 13, 1967, January 6, 1968, and January 11, 1968, when 63, 65, and 66 feet per day were driven, respectively. The peak advance per shift was maintained during the week of September 11-16, 1967, for an average of 14.10 feet per shift. Generally, from May 1967 to the end of south heading operations in June 1968, 
over 13 feet per shift was maintained. Further, from the fal1 of 1967 to the end of operations, the advance per shift approached, and occasionally exceeded 14 feet.

\section{North Heading}

The first round in the north heading was fired at 4:30 p.m., November 14, 1966. Excavation from the north heading was continued for 15,393 1inear feet of tunnel, requiring 1,316 shifts and 2,888 rounds for completion. The delay in beginning the north heading was partly caused by difficulties with additional rock excavation at the Burrows Creek area near the north portal (to be described in the section on special portal problems). Table 4 1ists month1y progress from the north heading.

TABLE 4. - Tunne1 driving progress, north heading

\begin{tabular}{|c|c|c|}
\hline Reporting period & $\begin{array}{c}\text { Reporting period } \\
\text { progress, feet }\end{array}$ & $\begin{array}{c}\text { Cumulative progress, } \\
\text { feet }\end{array}$ \\
\hline Nov $, 14,1966-$ Dec $_{0} 1,1966 \ldots \ldots \ldots \ldots$ & 259 & 259 \\
\hline Dec. 1, 1966-Dec. 24, 19661 $\ldots \ldots \ldots$ & 814 & 1,073 \\
\hline Jan. 4, $1967-$ Feb. $1,1967 \ldots \ldots \ldots \ldots$ & 777 & 1,850 \\
\hline Feb. 1, $1967-\operatorname{Mar} .1,1967 \ldots \ldots \ldots \ldots$ & 602 & 2,452 \\
\hline Mar. 1, 1967-Apr. 1, 1967........ & 987 & 3,439 \\
\hline Apr. 1, 1967-May 1, 1967......... & 1,266 & 4,705 \\
\hline May 1,1967 -June 1, 1967......... & 1,240 & 5,945 \\
\hline June $1,1967-J u 1 y 1,1967 \ldots \ldots \ldots \ldots$ & 1,020 & 6,965 \\
\hline July $1,1967-$ Aug $1,1967 \ldots \ldots \ldots \ldots$ & 1,032 & 7,997 \\
\hline Aug. 1, 1967-Sept。 $1,1967 \ldots \ldots \ldots$ & 928 & 8,925 \\
\hline Sept. $1,1967-$ oct, $1,1967 \ldots \ldots \ldots$ & 903 & $9 ; 828$ \\
\hline Oct. $1,1967-$ Nov $, 1,1967 \ldots \ldots \ldots$. & 939 & 10,767 \\
\hline Nov. 1, 1967-Dec. 1, 1967......... & 142 & 10,909 \\
\hline Dec. 1, 1967-Dec. 24, 19671 ...... & 188 & 11,097 \\
\hline Jan. 3, 1968-Feb. 1, 1968........ & 839 & 11,936 \\
\hline Feb. 1, 1968-Mar. 1, 1968......... & 891 & 12,827 \\
\hline Mar. 1, 1968-Apr. 1, 1968......... & 940 & 13,767 \\
\hline Apr. 1, 1968-May 1, 1968......... & 881 & 14,648 \\
\hline May 1,1968 -June $1,1968 \ldots \ldots \ldots \ldots$ & 629 & 15,277 \\
\hline June 1,1968 -June $11,1968^{2} \ldots \ldots \ldots$ & 116 & 15,393 \\
\hline
\end{tabular}

Voluntary shutdown for holiday.

une 11, 1968: heading bolted.

Peak daily advances from the north heading were recorded on January 17 , and May 10, 1967, when 66 feet per day were driven. The peak advance per shift was maintained during the week of July 31 to August 5, 1967 for an average of 13.61 feet per shift. Generally, from May 1967 through November 1967, the average advance per shift exceeded 13 feet.

Appendix A gives more detailed project summaries from both the south and north headings. 
Operating Cycle

\section{$\underline{\text { S1iding F1oor and Dril1 Jumbo }}$}

Two identical sliding floors by Jacobs Associates, San Francisço, Calif., 6 were utilized for this project, one for each heading (22). ${ }^{7}$ The sliding floor is essentially a method whereby working sections of roadbed near the face of a tunnel may be sectionally moved forward to provide continuous work operations at the heading face. Only a short transition length of track and utility connections are required at the trailing edge. The selfpropulsion concept depends on the weight distribution between three operating sections. A section that is being moved must always be lighter in weight than the weight of the remaining stationary sections. Weight distribution may be enhanced by transfer of rail equipment to other sections. Further details of the sliding floor are described in the literature (23-24).

Each sliding floor was 418 feet 1ong, and consisted of three operating sections: an 82-foot forward section, 268-foot center section, and trailing section 68 feet in length (sections are oriented from front to rear with respect to the face of the tunnel heading). An operating section is defined on the basis of the self-propelled length. However, to facilitate field erection, the floor was preconstructed in 15 segments--nine segments, 30 feet 1ong; two 32 feet long; two 24 feet 1ong; and one each, 16 and 20 feet 1 ong.

Each segment consisted of a frame fabricated from 8-inch WF 31 -pound side members and 8- by 3-inch, 18.7-pound channel cross members on 5-foot, 3-inch centers, maximum. The space between the structural framing members was solidly filled with 4 - by 6 -inch rough timbers. This malnly provided the foundation upon which 80 -pound rail could be securely spiked down. The entire bottom surface of all segments was covered with 3/8-inch-thick steel plate, integrally welded. The most forward section was also steel plated on the top surface to provide a slick plate for mucking and blast protection.

The total weight of al1 30 segments for each sliding floor was approximately 400 tons, distributed as follows:

Weight, 1b

Structural steel members..................

Rail and switches....................... 298,400

Timber fill.........................

Hydraulic system......................

Utility lines........................

Maximum muck load.....................

Dril1 jumbo and mu.cking machine............

Total loaded and equipped weight.

49,300

67,000

10,500

8,400

185,400

180,000

799,000

\footnotetext{
${ }^{6}$ Reference to specific trade names is made for identification only and does not imply endorsement by the Bureau of Mines.

${ }^{7}$ At the time of usage, this particular sliding floor was the fourth installation in the United States, and the tenth in the world (23, p. 8).
} 
Additional protective steel plates were welded along the sides. These plates also framed the utility lines incorporated along each side of the sliding floor (fig. 8).

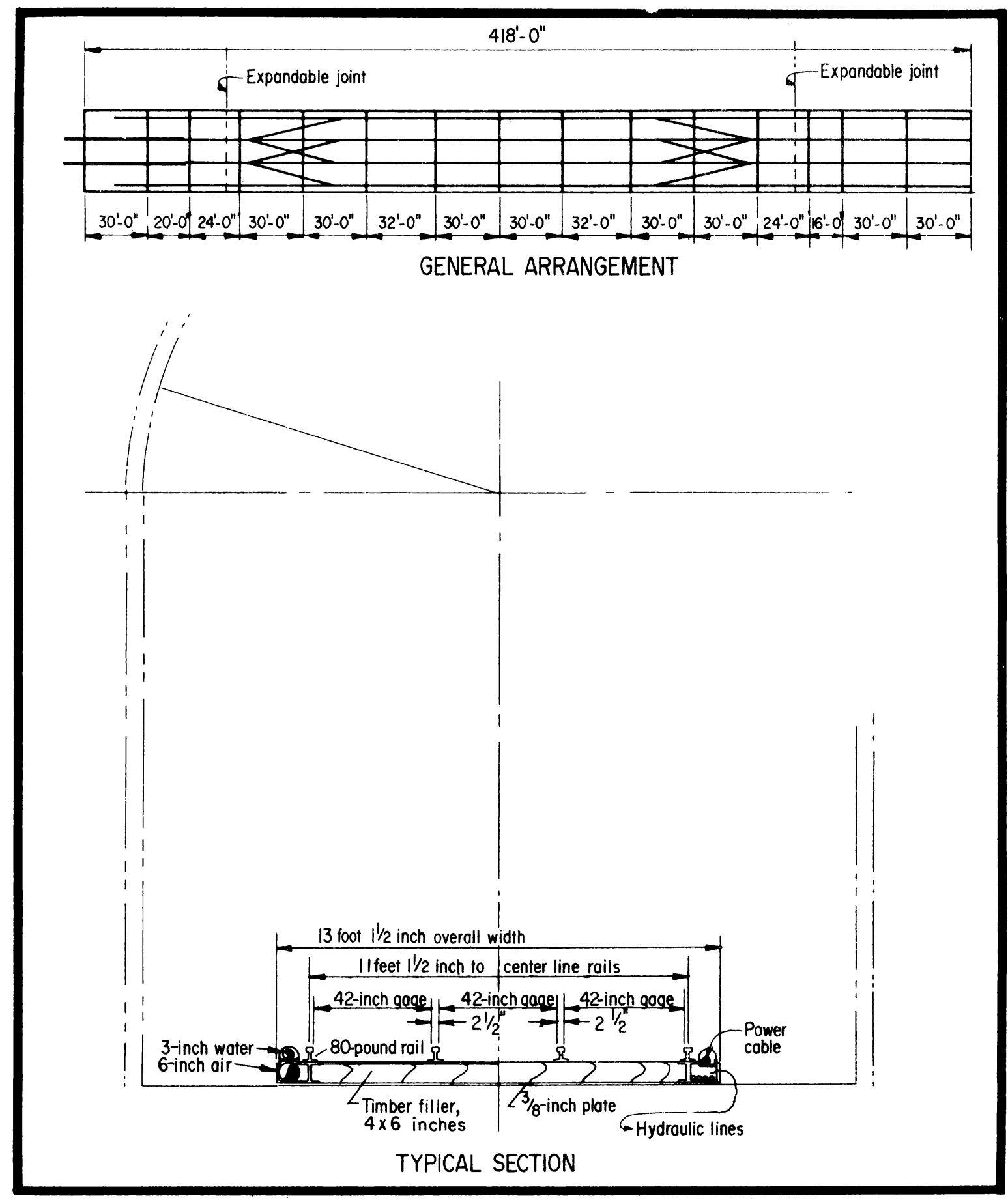

FIGURE 8. - General dimensions of sliding floor. 
As noted, the sliding floor had double, 42 -inch gage track along the centerline in a California switch configuration. The extreme outer rails were utilized for the gantry drill jumbo with a track gage of 11 feet, 1-1/2 inches. Complete seven-car muck trains could then be switched entirely on the sliding floor. However, only equipment with 42 -inch track gage had access to the sliding floor on continuous track, the drill jumbo being confined exclusively to the sliding floor structure. Al1 operations normally done within a distance of a few hundred feet of the face were carried out on the sliding floor (that is, drilling, mucking, and support installation).

Advance of each individual sliding floor section, either pushed or pulled, was accomplished by a self-contained hydraulic system located at the right rear of the sliding floor (fig. 9), and driving three parallel double-acting hydraulic cylinders mounted between sections. The hydraulic system operated at 2,500 psi with a 60-gpm pump, 150-ga11on reservoir, and 100-hp electric motor. Maximum stroke of the 8 -inch diameter hydraulic cylinders was 3 feet.

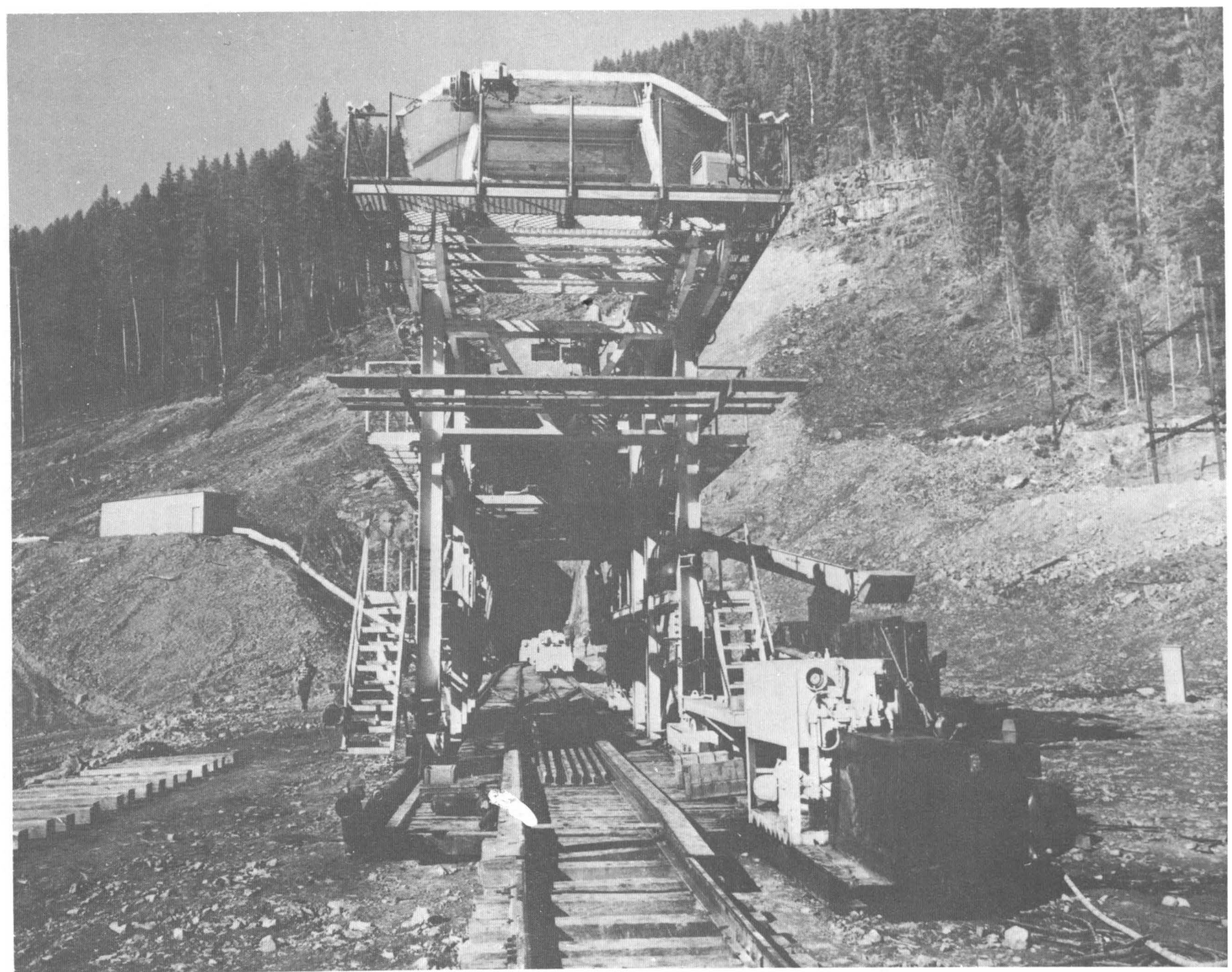

FIGURE 9. - Rear view of jumbo and sliding floor. 
About 1,600 1b force was required for the two end sections, and 1,250 $1 \mathrm{~b}$ force for the center section (calculated). Actual operating pressures were nearly 2,500 psi.

Commonly, the sliding floor was moved during the mucking cycle, while the dri11 jumbo was parked on the rear section when mucking was in progress on the front section. Initially, the forward section was advanced a full 3 feet, followed by the longer center section, and finally the shorter rear section was pulled into an abutting position with the first two sections to complete the sliding floor advance cycle. An entire sliding floor cycle could be accomplished in a few minutes. Few difficulties were encountered in operating the two sliding floors.

The decision to use the sliding floor was based on the straight-line tunnel alinement, the large tunnel size, use of a full-face excavation method, and the likely encounter of generally competent rock conditions. In operation at the heading, the sliding floor offered other increased advantages in overall excavation efficiency. The stable track foundation provided by the sliding floor significantly aided access to and from the heading by the dri11 jumbo. The forward section of the sliding floor also provided a smooth platform on which muck could be readily handled. The length of the floor allowed a continually available section of prebuilt double track, complete with Ca1ifornia switches, for handling an entire muck train. These factors cumulatively saved valuable time during all portions of the excavation cycle. A short section of haulage track was laid at the trailing end of the sliding floor, and this could be done at a convenient time.

To be compatible with the large tunnel dimensions and to be used in conjunction with the sliding floor, as well as to perform drilling and support functions at the heading face, two three-deck jumbos were specially fabricated for this project, one for each heading. These jumbos were designed and constructed by Moran Engineering, Los Angeles, Calif.

Common features for both drill jumbos included the following: three above-grade working levels, cherrypicker for the Moran cars, and hydraulic lifting tongs to raise steel sets into final position.

The top deck was also used to carry steel supports and timber. It was supplied during the drilling cycle. The total weight of the unequipped jumbo was 53.13 tons. In operation, the drill jumbo was moved, as necessary, by one of the locomotives' between the rear of the floor and the tunnel face.

The drill jumbo had an overall length of 63 feet, including forward and rear cantilever sections. Overall width was 17 feet at the lower and middle decks. Height to the top deck from track grade was 21 feet 7 inches. A minimum inside clear dimension of 9 feet allowed passage of all muck trains and loading equipment. The lower deck was hinged for this passage. An internal open bay in the jumbo, 7 by 21 feet, contained the cherrypicker assembly. Support steel was lifted onto the top deck at the rear overhang and into placing position by the hydraulic-powered cherrypicker assembly. Mounts for the 11 
drills were placed as schematically shown in figure 10. Placement of the features discussed and general overal1 dri11 jumbo arrangement are shown in figure 11 .

\section{$\underline{\text { Drilling }}$}

Drilling was done from the four-1evel gantry jumbo, as described above. Each jumbo mounted 11 Gardner-Denver D-93 drifters--four on the invert-grade level, two on the second leve1, two on the third leve1, and three on the top leve1. The drifters were mounted on hydraulic booms with 14 -foot carriages. In addition, a single Gardner-Denver DH-143 drifter with special boom was mounted on the third level for drilling two 5-inch-diameter holes for the "burn cut" portion of the round. All holes for rounds ranged from about 12 feet for ground supported with rock bolts to 4 feet in rounds having poor rock conditions and supported with closely spaced steel sets. Drill steel, however, was in 12-foot lengths, 1-1/4 inch round, and with $1-3 / 4$ inch detachable tungsten carbide bits.

Four additional general-purpose Gardner-Denver D-93 dril1s, with short carriages, were used to drill holes for rock bolts as needed. They were placed on the level with the burn-hole drill and on the top decks of the jumbo.

The tunnel headings were advanced by the full-face method. Heading dimensions were 21 feet wide and 29 feet, 8 inches high, with 6 inches between the A-1ine and B-1ine. The normal round was standardized into 107 blast holes and two burn holes. Figure 12 illustrates a typical round pattern. The two burn holes were spaced about 1 foot apart, as were the six drill holes centered about the burn holes. This pattern was spaced about 3 feet below the springline. A11 other holes were spaced at approximately 30 inches.

\section{Explosives and Blasting}

Rounds were loaded upon completion of the drilling cycle. Electrical power to the heading area was disconnected and air-operated lighting used before the powder car containing two Moran prill pot machines was brought to the face. The majority of the approximately 2.1 million pounds of explosives used on the project was Hercules stick-type powder, as follows: Gelamite 2 ( $1-1 / 4$ by 12 inches, 40 percent), Extra Gel (1-1/4 by 8 inches, 60 percent), and a limited amount of Hercomix. Initially, ammonium nitrate (AN) was used (because of its obvious economy); however, its use was general1y discontinued at the preference of the contractor, except in the more competent ground using rock-bolt support.

Hercules Superdet blasting caps in 0 through 12 delays were used (fig. 12). The blasting circuit at the face was wired in parallel with a buss wire traversing the tunnel face.

Each hole was primed with a blasting cap and one to several sticks of 60percent powder. Approximately 34 of the lower holes, in addition to the six charged holes surrounding the 5-inch-diameter burn holes, were loaded with 


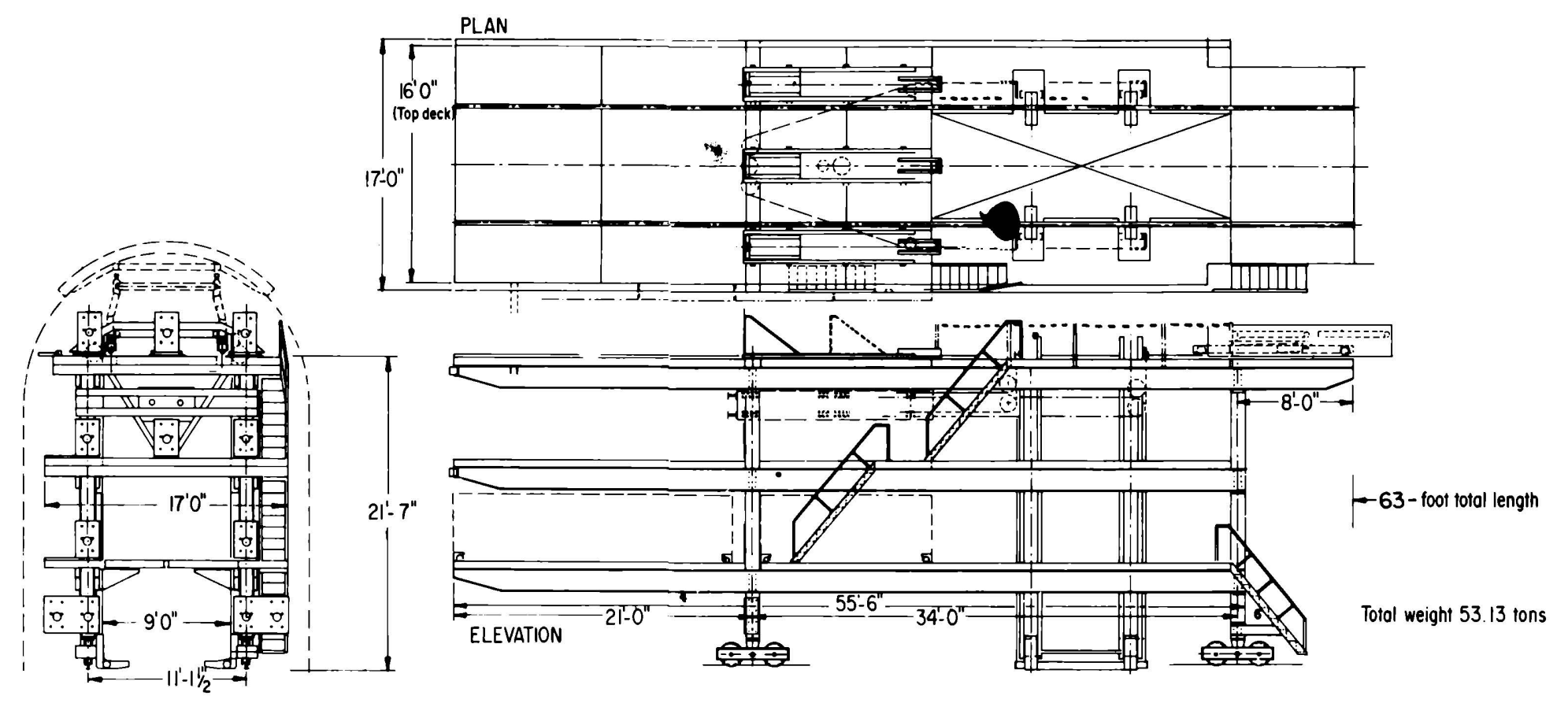

FIGURE 10. - Schematic of drill jumbo.

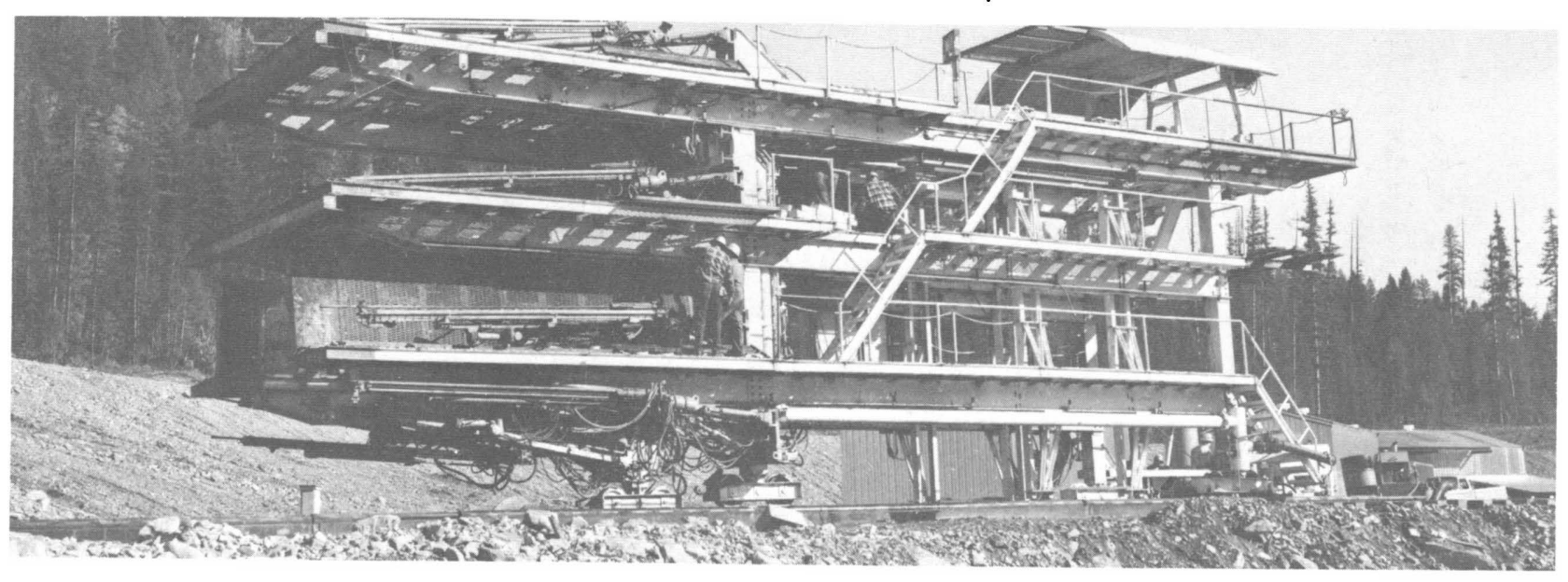

FIGURE 11. - Side view of drill jumbo. 


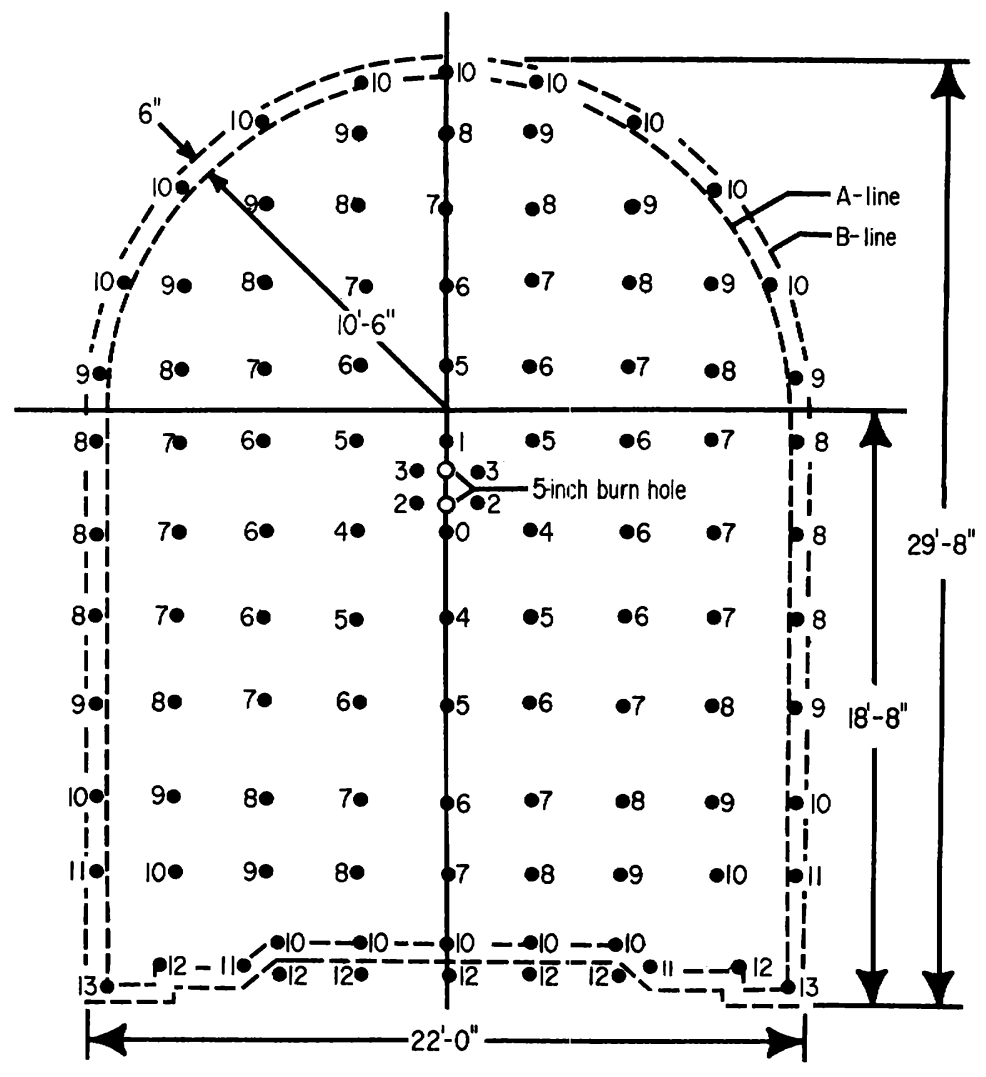

FIGURE 12. - Typical drill round pattern.
60 -percent powder. The remainder of the holes were usually loaded with 40 percent powder, except for those instances where, as discussed previously, the contractor elected to use AN for good rock conditions. For a typical 5-foot round, approximately 140 pounds of stick-type powder would be used. When AN was used, about 200 pounds of slurry was required. The overall average powder factor for the entire project was 2.86 pounds per cubic yard. The average overbreak for the entire project was calculated (으) as about 8.5 percent.

Following loading of the round, the drill jumbo was moved to the trailing edge of the sliding floor, about 400 feet from the face. A safety switch nearby the California

switch was activated by the tunnel walker while the loading crew returned to the firing switch, a minimum of 1,000 feet from the face. Following safety checks of the circuit and the area, all rounds were fired from this firing switch. As soon as the heading was ventilated (about 10 minutes) and checked for hazards, the muck wet down, and the face inspected for misfires, another operations cycle was begun.

A total of 2,888 rounds was fired in the north heading and 3,866 rounds in the south heading in 488 working days. The final "holing out" round was remotely fired at 11:10 a.m., June 21, 1968, by President Johnson, using a special circuit originating at his desk in the White House (44). Figure 13 shows the muck pile at the final round.

\section{Mucking}

Mucking was done with a Conway mode1 100-2 electric-powered mucking machine which was moved to the heading face as soon as permissible following blasting. The mucking machine had a 1-1/2-cubic-yard bucket, powered by a $150-\mathrm{hp}, 440$-vo1t electric motor that also propelled the mucker. An additional 40-hp electric motor powered the 42-inch conveyor mounted with the mucking machine. The conveyor loaded muck into trains of 13-cubic-yard Moran side-dump cars. Additional scaling and wetting down of the tunnel face, ribs, 


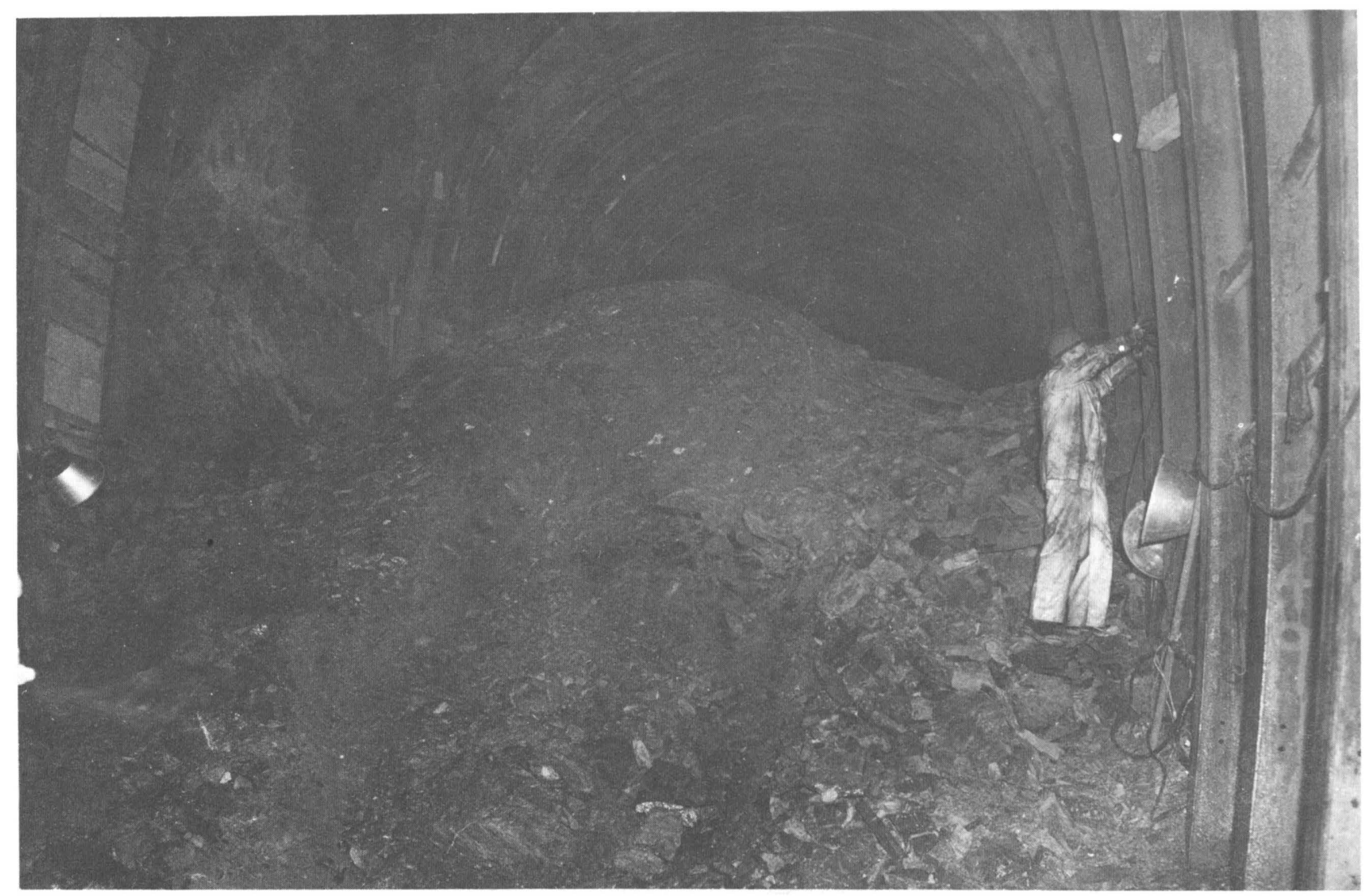

FIGURE 13. - Muck pile at final round, station $3157+01$.

and back were accomplished during the mucking cycle. A normal 5-foot round loaded about 17 to 20 cars, and was completed in about 1 hour. Some fines were left at the face to furnish a foundation for the sliding floor.

Two muck trains, made up of seven to eight cars each, handled loaded cars and positioned empty cars, respectively, for loading on the sliding floor. The train of empties was positioned alongside the train being loaded on the sliding floor. As a loaded train was moved away from the heading, empty cars were positioned to the mucking machine "on the fly." A third train was used for longer hauls to outside dumping sites. Additional muck cleanup along the invert was done at some distance behind the sliding floor with a Case model 310 backhoe. Muck from this cleanup was loaded into standby trains. This work was done during drilling and support cycles. It substantially reduced the amount of preparation required for succeeding concrete operations. Figure 14 shows the typical lineup of mucking equipment at the south portal. From foreground to background, note the Conway mucker, switching locomotives, muck train, and drill jumbo, respectively. All equipment shown rides on the sliding floor. Figure 14, at the south portal, and figure 35, at the north portal, also show the extensive rock bolting with chain link fencing at the rock cuts of both portals. 


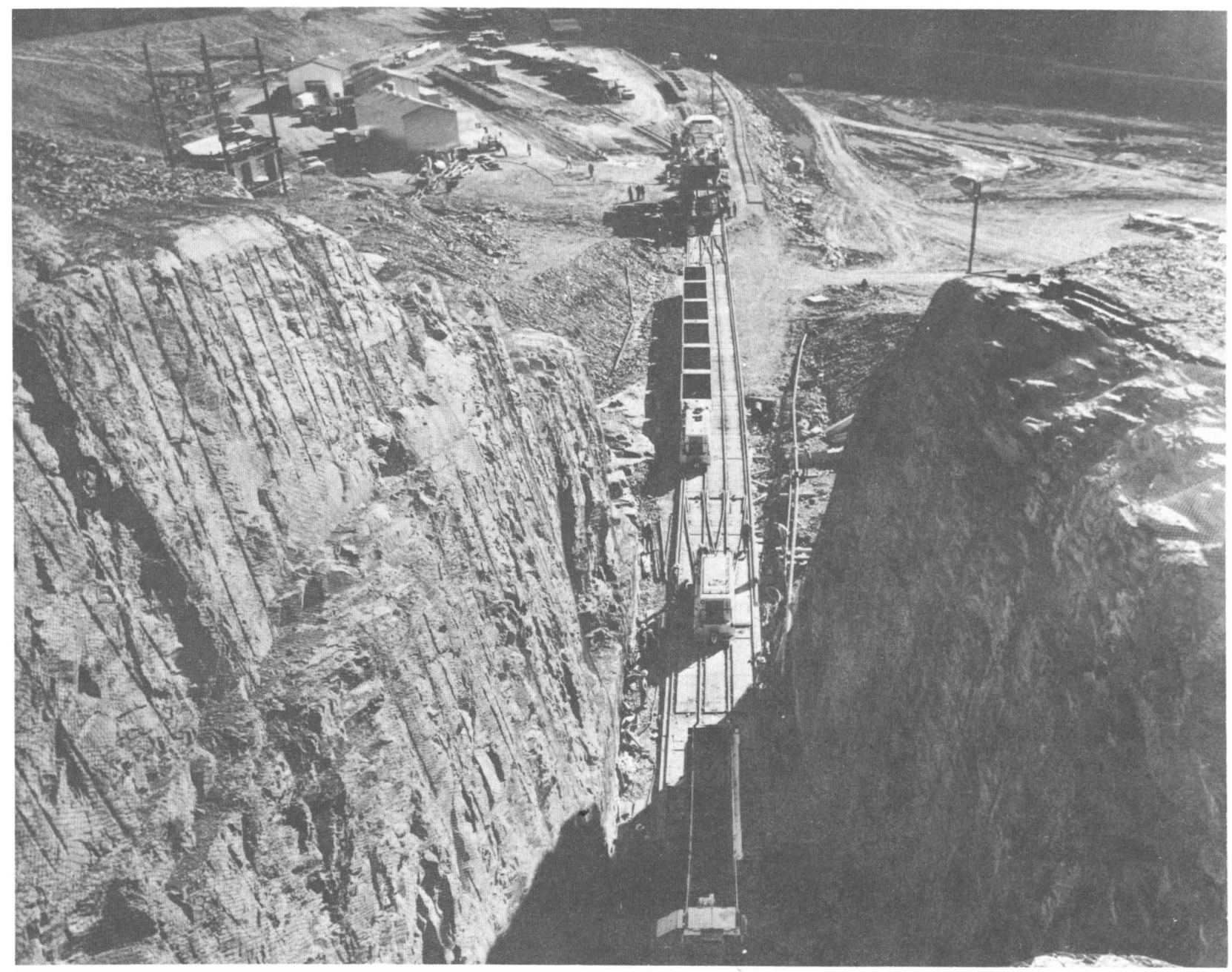

FIGURE 14. - Typical mucking equipment layout.

$\underline{\text { Haulage }}$

The contractor maintained five 25-ton P1ymouth diesel locomotives, model $\mathrm{JMD}$, for operations at each portal. All locomotives were equipped with waterdetergent exhaust scrubbers that were flushed daily. A railyard of 36 muck cars (13-cubic-yard capacity Moran side-dump cars) was required at each portal. Muck train makeup has been discussed previously. These trains were used exclusively for the mucking operation.

Muck trains were unloaded by a side-lift car dumper which operated from a parallel track about 300 yards from the porta1. Muck was then loaded by Caterpillar 988 loader to Euclid trucks for haulage to the railroad fill. Essentially all muck was placed in the railroad embankment, except for about 100,000 yards stockpiled at the south heading.

The rail haulage system consisted of 42 -inch gage track with 80 -pound rail laid on 6 - by 8 -inch ties, 5 feet 6 inches long, and spaced on 2 -foot centers. 
A movable California switch for train-passing was maintained between 1,000 and 2,000 feet behind the heading. It consisted of a 330-foot-long double-tracked section mounted on raised dollies (about 10 inches) that permitted rolling on the main track. The switch platform was designed to be easily moved by 1.ocomotive. When stationary, a series of supporting and blocking beams were installed under the platform. A 15-foot transition rail section at each end was used to ramp trains from the main track.

Ventilation

Each heading carried a 46-inch-diameter fanline along the crown to within the leading section of the sliding f1oor, or about 60 to 100 feet from the face. Tumsco Vanex blowers, model VB-1760, 48-inch diameter and 75-hp, were placed inline at not more than 4,000-foot intervals. Identical fans were also placed at the portal intakes. The fanline was operated as an exhaust system with a capacity in excess of 40,000 cfm.

The ventilation pipe was fabricated at the jobsite with a Tumsco portable "pipe-rolling machine" (patents pending). The machine formed a special interlocked crimped joint at overlapping strips with the trade name "Spir-L-OK". Rolls of 20 gage steel in 6 -inch widths were shipped to jobsite and fabricated into 46-inch-diameter pipe in 30-foot lengths. A hydraulic elevator platform mounted on a special railroad car was used for lifting fabricated lengths into place at the heading.

\section{Utilities--Air, Water}

Each heading was supplied with compressed air and water consisting of 8inch spiral-weld pipe and 4-inch tubing, respectively, with Victaulic couplings. Lines were carried near the heading where they were reconnected to the sliding floor and to the drill jumbo by flexible hoses. Waterlines near the portals, and for a distance into the tunnel, were insulated to prevent freezing in cold weather. The water supply was pumped from nearby streams to 10,000-gallon storage tanks above each portal. Normal water pressure was 75 psi.

Compressed air for each heading was supplied by three Gardner-Denver mode1 WF01M 1,160-rpm compressors, rated at 1,395 cfm and $115 \mathrm{psi}$. Each compressor was powered by a 250-hp General Electric motor. These compressors were used as demand warranted. Two additional Gardner-Denver model WFO compressors, rated at the same capacity as above, were connected in parallel to a 500-hp General Electric motor. Total installed compressor capacity was in excess of $6,000 \mathrm{cfm}$. Electric power was supplied to the identical compressor stations at 2,300-vo1t, 3-phase, ac.

\section{Electric Power}

A subcontract was awarded to construct a 24,900-vo1t powerline from a Bonneville Power substation at Trego, Mont., to substations at each portal. The substation reduced this to 4,160 volts for the primary tunnel powerline, where it was further reduced at transformer bays with circuit breakers and 
junction boxes for distribution at local working voltages in the tunnel. The tunne1 power cable was a 350,000 circular mill underground-approved system. The largest transformers in the tunnel were $300-\mathrm{kV}-\mathrm{A}$ heading transformers and $150-\mathrm{kV}-\mathrm{A}$ ventilation fan transformers. The highest voltage at the face was 440 volts, which was required by the Conway mucker. A number of smaller transformers supplied power for electric lighting which was widely used throughout the tunnel.

Thirteen transformer bays (along with 20 refuge chambers and three sectionalizing bays) were excavated at approximately 2,500-foot intervals. So as not to interfere with production, these openings were drilled out by an auxiliary crew as the heading advanced. Excavation was then completed on Sundays, in order that this interruption would not affect normal tunnel driving operations.

\section{Operating Cycle Summary}

In the preceding sections and in appendix A, many of the factors involved in the excavation cycle were discussed in detail. One measure of overall operating efficiency per round is the excavation cycle time. Table 5 summar zes an average excavation round based on 488 days of tunnel driving.

TABLE 5. - Time study of excavation cycle per round

\begin{tabular}{|c|c|c|c|c|}
\hline & \multicolumn{3}{|c|}{ Time required, minutes } & \multirow{2}{*}{$\begin{array}{l}\text { Percent } \\
\text { of total }\end{array}$} \\
\hline & $\begin{array}{l}\text { North } \\
\text { portal }\end{array}$ & $\begin{array}{l}\text { South } \\
\text { portal }\end{array}$ & $\begin{array}{l}\text { Project } \\
\text { average }\end{array}$ & \\
\hline \multirow{8}{*}{ 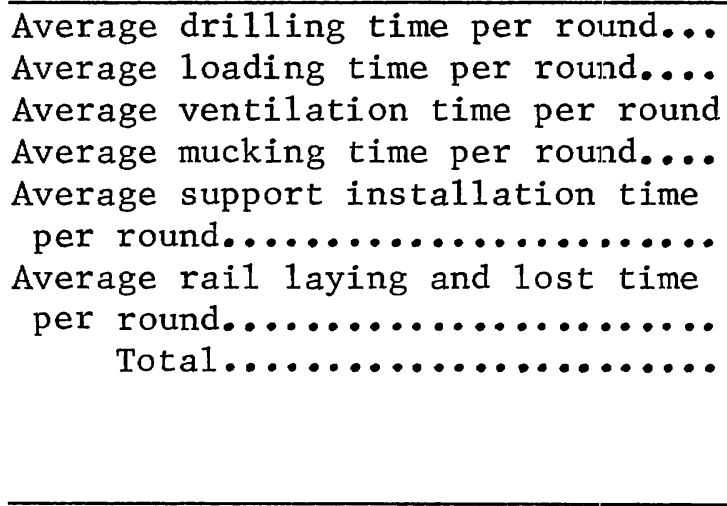 } & 60 & 51 & 54.4 & 27.7 \\
\hline & 26 & 26 & 26.3 & 13.4 \\
\hline & 9 & 11 & 10.0 & 5.1 \\
\hline & 67 & 47 & 55.7 & 28.3 \\
\hline & 46 & 39 & 42.0 & $21 \cdot 3$ \\
\hline & 10 & 7 & 8.0 & 4.2 \\
\hline & 218 & 181 & 196.6 & 100.0 \\
\hline & $\begin{array}{c}\text { ( } 3 \text { hours } \\
38 \text { minutes) }\end{array}$ & $\begin{array}{l}\text { ( } 3 \text { hours } \\
1 \text { minute) }\end{array}$ & $\begin{array}{c}(3 \text { hours } \\
17 \text { minutes })\end{array}$ & \\
\hline
\end{tabular}

Although the tabulated data are self-explanatory, the percentages for individual portions of the cycle are of interest. They are drilling, 28 percent; mucking, 28 percent; support, 21 percent; and loading, 13 percent. These four items account for 90 percent of the total excavation cycle. More complete cycle data are found in appendix A.

Little difference in individual cycle time is noted between the two headings, except for the mucking portion. This is due to the longer rounds pulled in the north portal. (See appendix A.) 


\section{Feeler Holes}

Feeler holes were drilled, with each regular heading round, mostly on the down-grade north heading because of the greater possibility of sudden water inflow. The total footage of feeler holes drilled during tunnel excavation was 58,056 feet. The maximum daily footage drilled from both headings was 252 feet; approximately 11 percent of the daily footage was over 200 feet and 39 percent under 100 feet per day. The overall daily average was 120 feet per day from both headings.

\section{Ground Water}

Except for the north portal and for some water-bearing fault zones, the entire tunnel lay below the local ground-water table. Estimates of water infiltration by the Corps of Engineers, based on pressure tests in exploratory drill holes, indicated a maximum possible inflow of approximately 1,000 gallons per minute (gpm). However, that portion of tunnel driven under Fortine Creek, and especially through the Twin Meadows Fault zone, did not encounter water flows as expected (possibly owing to the seasonal time the tunnel was driven through these zones). A maximum water flow of $160 \mathrm{gpm}$ (plus that water removed in the saturated muck) was recorded for March 1968. A temporary water inflow estimated at 800 to $1,000 \mathrm{gpm}$ was encountered during a few days in March 1968 when the Gray Creek Fault was penetrated, but this flow quickly subsided.

Water was pumped from the down-grade north heading by submersible air and electric pumps into a 12-inch Victaulic coupled pipeline. A Gorman-Rupp mode1 75 pump with 100 -hp electric motor pumped water from this line into Fortine Creek. The total water pumped (pay item) was 6,652,952 cubic feet. Water flow from the south heading, driven upgrade, was free flowing and not recorded. An average water inflow throughout the construction period is estimed as about $40 \mathrm{gpm}(\underline{39})$. The lower than expected ground water inflow was reflected by a deliberate program of surface drainage along those streams that coincided with the tunnel route.

\section{Smooth-Wa11 Blasting}

In meetings between representatives of the contractor, Burlington Northern, the Corps of Engineers, and Hercules Powder Co., it was agreed to perform smooth-wa11 blasting experiments in an attempt to obtain a more uniform cross section with decreased overbreak across the tunnel arch.

Standard practice on these smooth-wall rounds across the crown section above the springline was the use of 60-percent Hercules trim powder at a loading density of $1 / 4$ pound per foot. The smooth-wall portion of the round was fired with No. 12 delays. The remainder of the round was drilled, loaded, and fired with the contractor's standard drill pattern. No other changes were suggested in the normal drilling and blasting practice, unless these become apparent from the field experiments. 
Trial smooth-wa11 rounds began June 25, 1967, and continued for the following 2 weeks. Primary effort was expended in the south portal, but trials were also performed in the north heading. Ground conditions were considered good with moderately to highly fractured, but tightly jointed, rock. No water inflow occurred as the trial rounds were advanced. These initial smooth-wall trials were 7 -foot rounds with perimeter holes along the arch loaded with 4 feet of Hercules trim powder per hole. A perimeter hole spacing of 30 inches required 13 holes across the arch. Observed rock breakage was largely along joint planes.

Succeeding rounds were drilled to 12 -foot depth, and the perimeter hole spacing was reduced to 24 inches. This hole spacing required 18 holes around the perimeter. Additional relief holes were also drilled along the perimeter. The powder factor was maintained at $1 / 4$ pound per foot. Improvement in rock breakage seemed to occur with more remnants of drill holes evident. No overbreak occurred, and little scaling was required.

Results of the smooth-wall rounds indicated generally uniform breakage across the crown, although breakage to better developed joint planes was the rule. Residual drill holes were frequent, but the characteristic knifelike slicing action of smooth-wall blasting was not overwhelmingly demonstrated. Scaling and barring down was regularly continued during the smooth wall rounds, and minimum rock bolting was used to provide safety. It was concluded from the smooth-wall experiments that the tunnel arch section was somewhat more uniform with limited overbreak only in locally fractured zones.

Nevertheless, smooth-wall blasting was discontinued, primarily because of economic considerations based upon the following:

1. The contractor believed that the time required for additional drill holes would disrupt the normal drilling cycle.

2. Consequent1y, the drilling load for the three drill machines on the jumbo's top deck would be increased.

3. Smooth-wall blasting would require special powder in addition to the norma1 powder.

4. It could not be determined if positive improvement over existing blasting practice was being achieved by smooth-wall blasting (this was attributed to the closely jointed rock structure).

5. For the wel1-developed jointed and variable rock conditions (particularly prevalent at the time on the south heading), the use of the normal support system would still be required.

6. Any increased rock stability could not be evaluated in the smoothwa11 blasted sections. 
Since a sufficiently satisfactory arch section was already being produced, the improvement made by smooth-wall blasting was considered to be limited; hence, no further experiments were made to improve the dri11 and blast pattern.

\section{Laser Surveying}

In addition to standard optical surveying instruments in which both horizontal and vertical control were carried independent1y with a Wild T-1 -AE theodolite and a Wild N-2-E level, helium-neon gas laser mode1 5200 instruments by Perkin-Elmer Corp., Norwalk, Conn., were used. They emit a visible ruby-red beam (6328 A) optically collimated with 20 -miliimeter 1ens. The instrument was mounted on top of a Lietz 18-inch dumpy level by two yoke mounts having both horizontal and vertical adjustments. Normally, the laser was used to sight ahead and the level was used as a back sight.

The leve1 was mounted on a tripod head that was in turn mounted on a 2 inch-diameter threaded pipe. The entire unit was screwed into a baseplate with a vertical adjustment of about 8 inches. The baseplate assembly was attached to the tunnel rib by rock bolts at each laser station. Each laser setup was always mounted 4 feet above foot block elevation. Some protection to the laser and its accompanying power supply was provided by means of plywood covering and plastic canopy. A steel plate shield was mounted in front of the laser station for blast protection.

To furnish visible working line and grade on a 24-hour basis, duplicate laser setups were maintained on each tunnel rib. (To provide continuous service while some laser units were being repaired, seven laser units were available at one time.) As a check on alinement of the laser, 6-inch-wide metal plates with $1 / 2$-inch holes were welded onto the steel sets at approximately 200-foot intervals soon after each station was installed.

A laser was placed no closer than 450 feet behind the face, or near the trailing section of the sliding floor. New stations were prepared at 1,000foot intervals as the heading was advanced. Thus, a maximum distance between laser stations to the face would be 1,450 feet. This distance between stations was sufficient for 2 to 3 week's working time on each setup.

Only one model 5200 laser unit was used to provide line and grade for the arch and wall concrete form work. Line was projected 2-1/2 feet offset from centerline by a laser unit mounted along the tunnel arch. Grade was projected by spad and stringlines to the form work for the curb concrete. In this manner, line was successful1y projected up to 1,800 feet from the laser unit. 
THE GROUND SUPPORT PROGRAM

\section{Temporary Support}

Support Selection

Available geologic information, such as discussed in preceding sections, gave the following preconstruction estimate of rock types:

\begin{tabular}{|c|c|c|}
\hline & Feet & Percent \\
\hline stratified rock............... & 13,600 & 38.5 \\
\hline Moderately jointed rock....... & 14,000 & 39.7 \\
\hline Blocky and seamy rock..... & 4,600 & 13.1 \\
\hline Crushed rock.............. & 2,900 & 8.2 \\
\hline Squeezing rock............ & 200 & 0.5 \\
\hline
\end{tabular}

This estimate was based on the rock classification method given by Terzaghi (31). Support estimates from this rock classification indicated at least 20 percent would require heavy steel sets, 40 percent would be medium steel sets, and the remaining 40 percent could be supported with rock bolts.

Support selection considered was rock bo1ts, steel ribs, timber supports, and high-strength steel supports.

Timber supports, although the most economical material, would require an additional 8 to 12 inches of rock excavation about the opening periphery and necessarily must be replaced later with more expensive concrete. Labor cost and installation time would also be greater for timber support than for ordinary steel rib support. Timber support was therefore rejected.

High-strength steels were also investigated. To obtain an economic advantage it would be necessary to reduce the section depth an estimated 2 inches. Although the high-strength sections were found adequate for arch sections, they were found inadequate for the vertical legs because of the column effect due to reduced depth of section. The use of different size and grade of support members was not considered feasible in the field because of connections.

Typical rock sections supported by rock bolts anticipated the use of 3/4-inch-diameter rock bolts, 8 to 10 feet long, in a nine-bolt pattern across the arch. Allowance for field variation depending on rock structure was provided.

Three horseshoe rib sections of A36 steel were developed: 6-inch, 20pound sections for ordinary support; 8-inch, 34.3-pound sections for heavier vertical loads; and an 8-inch, 34.3-pound section with invert strut for squeezing ground or side loading. Size and spacing were to vary depending on rock conditions encountered during tunnel driving. Field modifications as necessary were permitted in the event that load conditions were not as anticipated. Figure 15 gives typical dimensions of these sections, except the invert strut. 


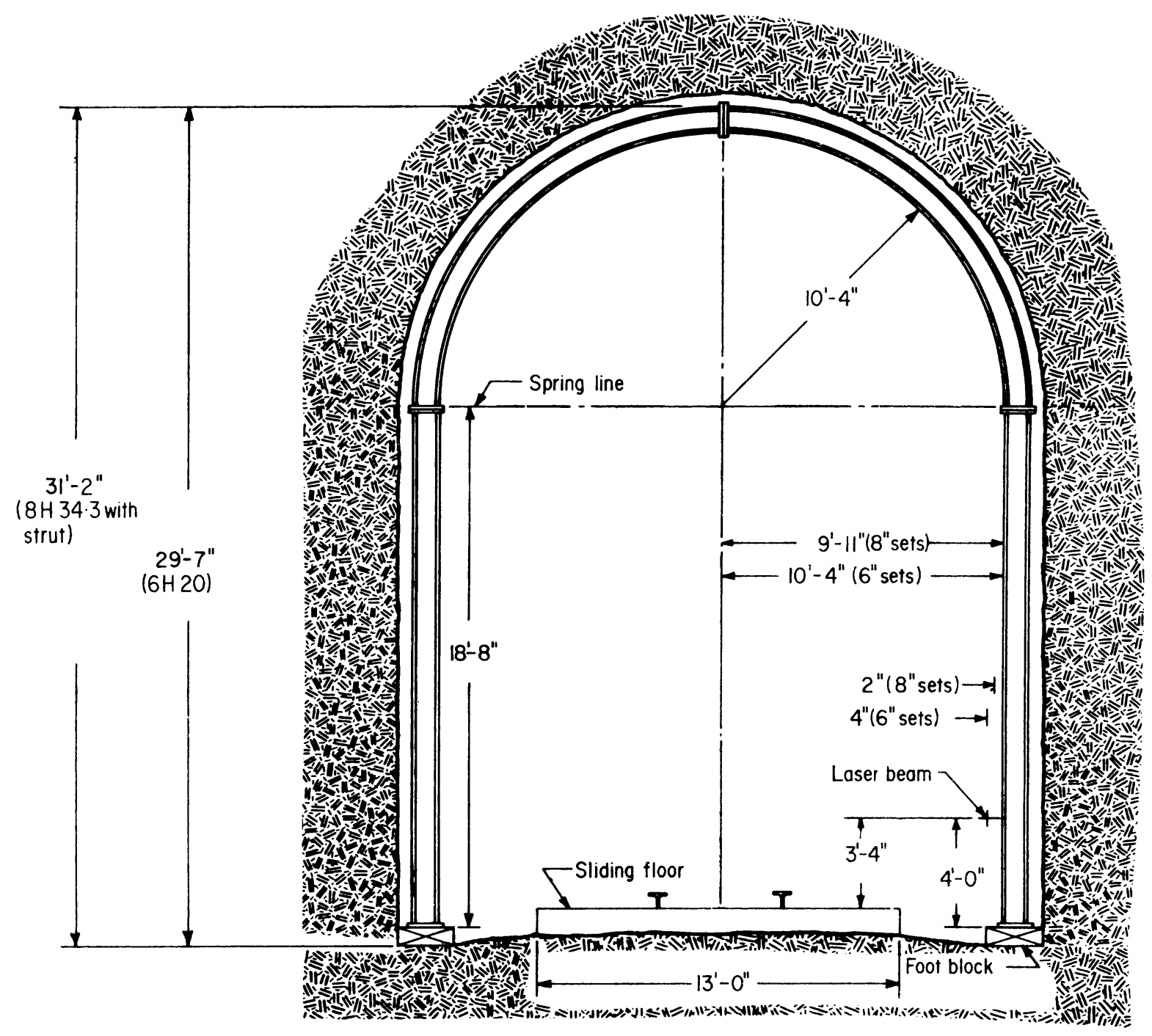

FIGURE 15. - Typical dimensions for steel sets.

Steel tunnel supports were designed for both bending and axial loading assuming maximum concentrated loads on blocking points not to exceed 4 feet. Arch sections were designed as a flexible member with blocking assumed at the crown and springline; additional blocking would be established as necessary, but not to exceed 4-foot spacing. Spacing of support sets was not to exceed 4 feet on centers for the 6-inch, 20-pound sections at a ground support design limit of 10 feet of free, gravity-loaded rock; and 22 feet of rock load for the 8-inch, 34.3-pound sections. Design methods closely followed those in reference 31 (ch. 11). Support design calculations were made by the supplier, Commercial Shearing and Stamping, by the Corps of Engineers, and at jobsite (35). 


\section{Structural Steel Support}

Approximately 73 percent of the total tunnel was supported by structural steel members with timber lagging--nearly 80 percent of the south heading and 63 percent of the north heading. Figure 16 is a typical scene showing the north heading being carried by steel support. Steel support specifications were covered in the contract under section 4 (43).

As mentioned, design calculations indicated the weakest member of the steel support set was the leg post. To offset this and prevent lateral

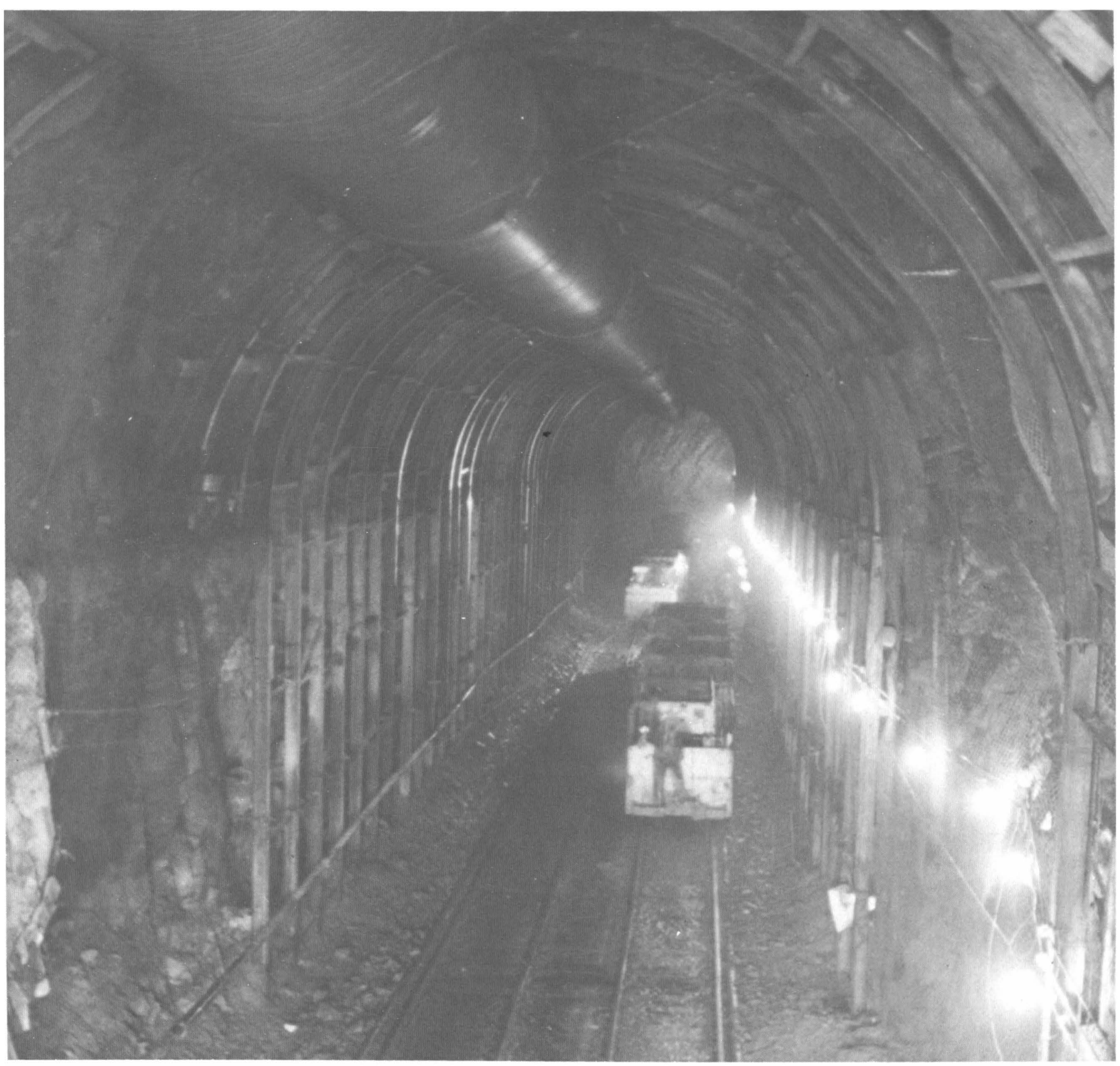

FIGURE 16. - Steel support in north heading. 
movement, the legs were reinforced by two rock bolts, one on each side of the leg, placed about 3 feet above the invert, with a connecting steel strap. This scheme effectively anchored the leg to the rock. In some cases, double sets of these anchors were installed (fig. 17). This anchorage also

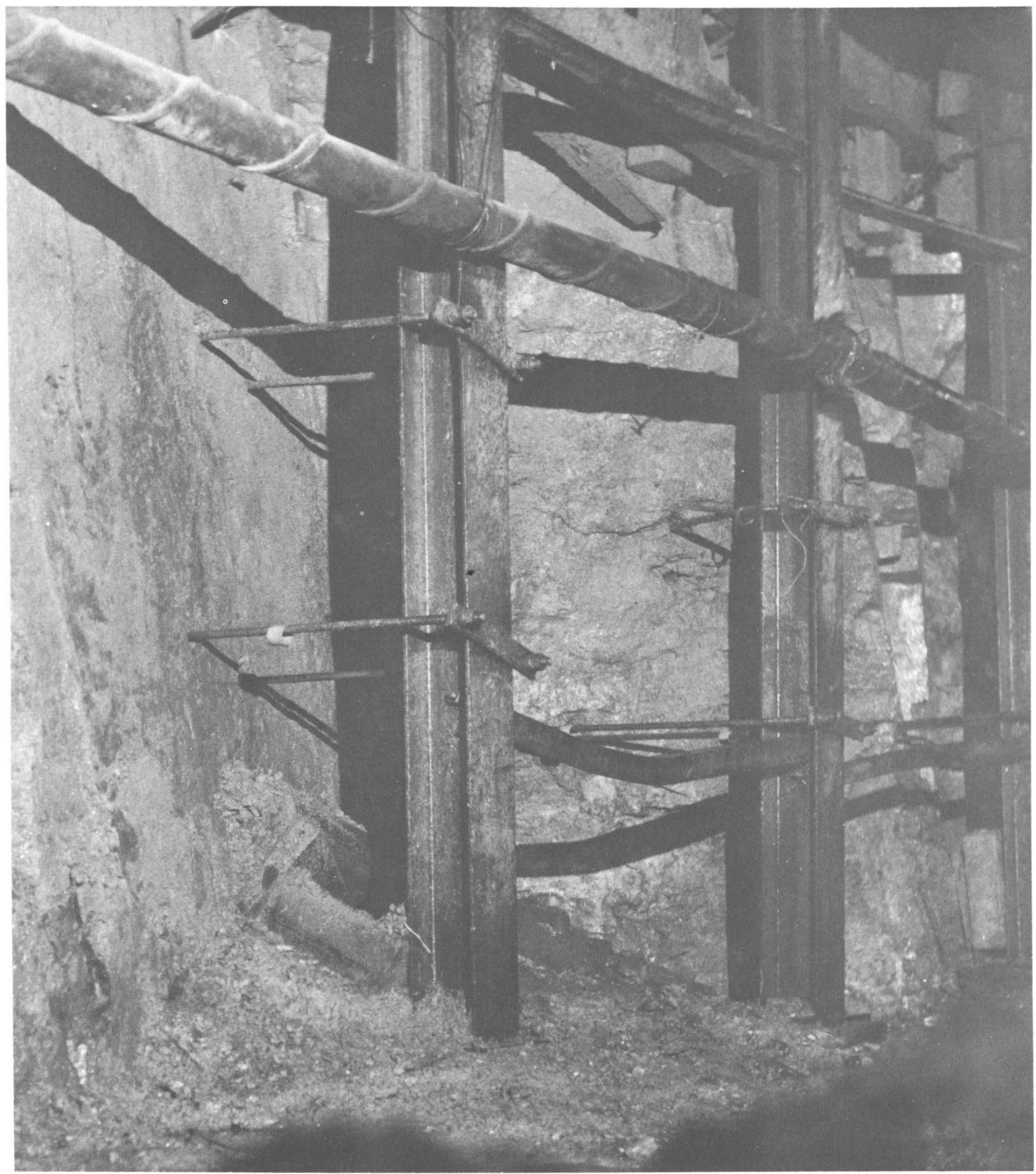

FIGURE 17. - Rock-bolt anchorage for support legs. 
aided support of later concrete curb forms, but was not the entire means of support.

Sectional steel sets brought in on service cars were raised and temporarily stored on the top jumbo deck. Steel sets were raised to the top deck using the hydraulic-powered cherrypicker on the jumbo (see figs. 10 and 11). The posts were raised from the tunnel invert using air tuggers. Sets were surveyed to line and grade using the laser.

Average timber consumption per set for blocking and lagging was about 900 board feet, based on amounts delivered to the jobsite. With wastage and other loses, this computed to about 750 board feet, installed. Upon concreting, all timber projecting inside the steel was removed and some additional timber was removed at other locations to facilitate concrete placement in areas of heavy overbreak.

Approximately 50 percent of the tunne1 was carried by 6 -inch steel sets: 12,700 feet from the south heading and 5,100 feet from the north heading. Such support was some 10 percent greater than predicted. A total of 72 sections were placed using 6 -inch sets; 38 were longer than 100 feet and 34 less

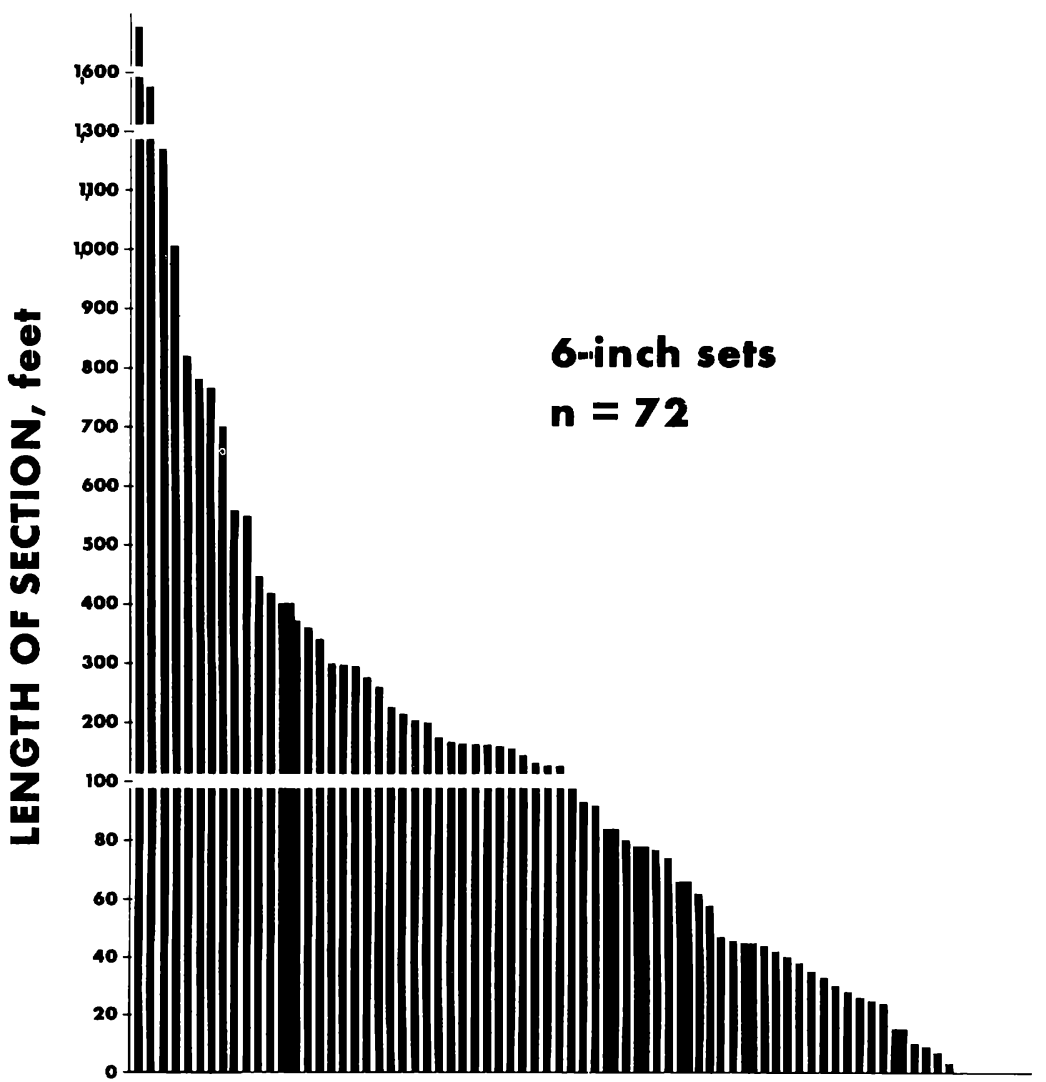

SECTIONS

FIGURE 18. - Distribution of tunnel lengths supported with 6-inch sets. than 100 feet (fig. 18).

The longer sections ranged up to 1,675 feet, but averaged 415 feet. The shorter sections averaged about 45 feet. Nearly every longer section in the south heading was preceded and followed by rockbolted sections, while in the north heading, about half the 6-inch sets were preceded and followed by rock bolts, and half were preceded and followed by 8 -inch sets. The south heading almost always alternated support from 6 -inch sets to rock-bolted sections, except across the E1k Mountain Fault. Much of the steel installed in the south heading was installed largely as a safety precaution against spalling rock and fallout of larger blocks.

\section{Geologic mapping} indicated that ground carried by the 6 -inch sets was 
blocky to massive, moderately fractured to highly fractured, with zones of thinly bedded to concentrated bedding plane faults. Set spacing for 6-inch sets was almost always 5 feet; however, 4-foot spacing and alternate 8-inch sets were used across some fault zones. Also, refuge chambers and transformer bays were often supported with side-by-side 6 -inch sets across these openings.

Approximately 6,500 feet of tunnel was carried with 8 -inch steel sets in 58 sections. This is 18.5 percent as compared with a predicted 20 percent for al1 heavy stee1. Many of these sections were short, being placed across transformer bays and refuge chambers for additional support created by the 1 arger spans. The average length of a11 short sections was 40 feet. Almost always, these sections were placed with 4 - and 5-foot set spacing in 1ocally faulted zones.

Where ground was definitely faulted, 8-inch sets were usually used. Al1 of the 16 longer sections, totaling about 4,825 feet (ranging from 100 to 835 feet, and averaging 300 feet) were placed between E1k Mountain Fault and Davis Creek. A few sections were placed in rock classified as highly fractured with set spacings of 2, 3, and 4 feet and some at 5 feet. In several shorter sections through this zone, especially across the E1k Mountain Fault, support was often alternating 6 - and 8 -inch sets.

Visible inward movement at the footblocks and deformation in the leg posts of some sets was also evident in definitely faulted ground. This was noted in some 6-inch sets across Davis Creek Fault. Deformation occurred when progress of tunnel excavation allowed the sliding floor to be moved beyond these sets. A few sets required repair.

No 8-inch sets were followed by rock-bolted sections, except for only one instance, when a 20 -foot length of 8 -inch sets was followed by 27 feet of rockbolted tunnel. Otherwise, 8 -inch sets were always followed by 6 -inch or invert strut sections. Figure 19 shows the individual lengths of tunnel supported by 8 -inch sets.

Approximately 1,530 feet of invert struts were placed, al1 within fault zones. The invert struts were 8-inch, 34.3-pound members used in conjunction with 8-inch steel sets designed for side loads. The Twin Meadows Fault required about 360 feet of continuous invert struts on 1.5-, 2-, and 3-foot centers, and the Gray Creek Fault about 125 feet on 3-foot centers. The east branch of the Elk Mountain Fault, however, used invert struts on 4 -foot centers discontinuously over a length totaling about 1,700 feet. Ten sections of invert struts, ranging from about 20 to 250 feet and averaging 85 feet, were alternated with regular 8 -inch sets in about equal lengths. Nearly the entire length was lagged solidly. Interestingly, all invert struts were placed only between stations $3110+64$ to $3191+84$, where the above-mentioned faults occurred. This 8,020-foot length represented about 23 percent of the total tunnel length. Coincidentally, combined 8-inch sets and invert strut support was 22.85 percent of the total, compared with the estimate of 20 percent requiring heavier support. Figure 20 shows individual lengths of tunnel supported with invert struts. 


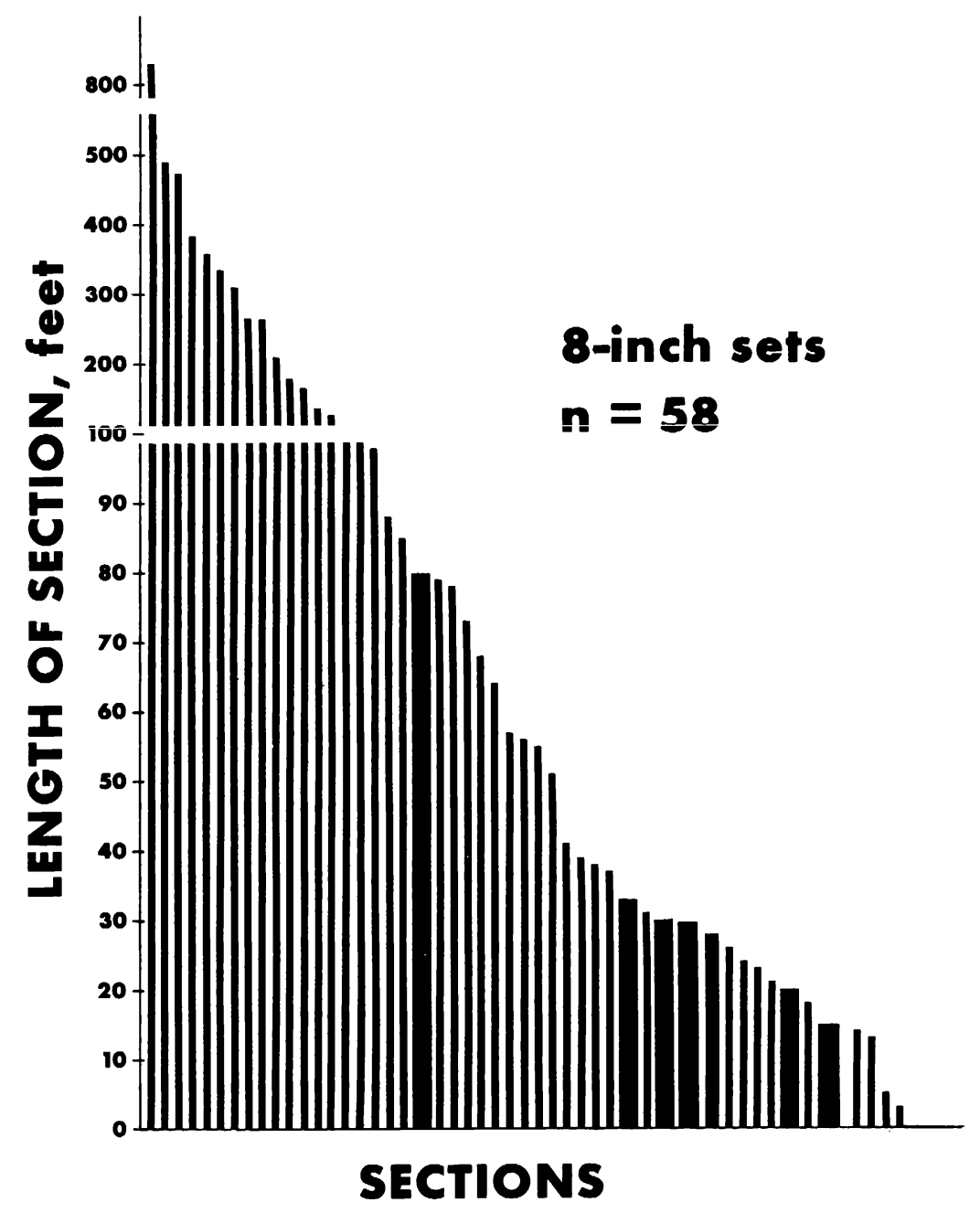

FIGURE 19. - Distribution of tunnel lengths supported with 8-inch sets.

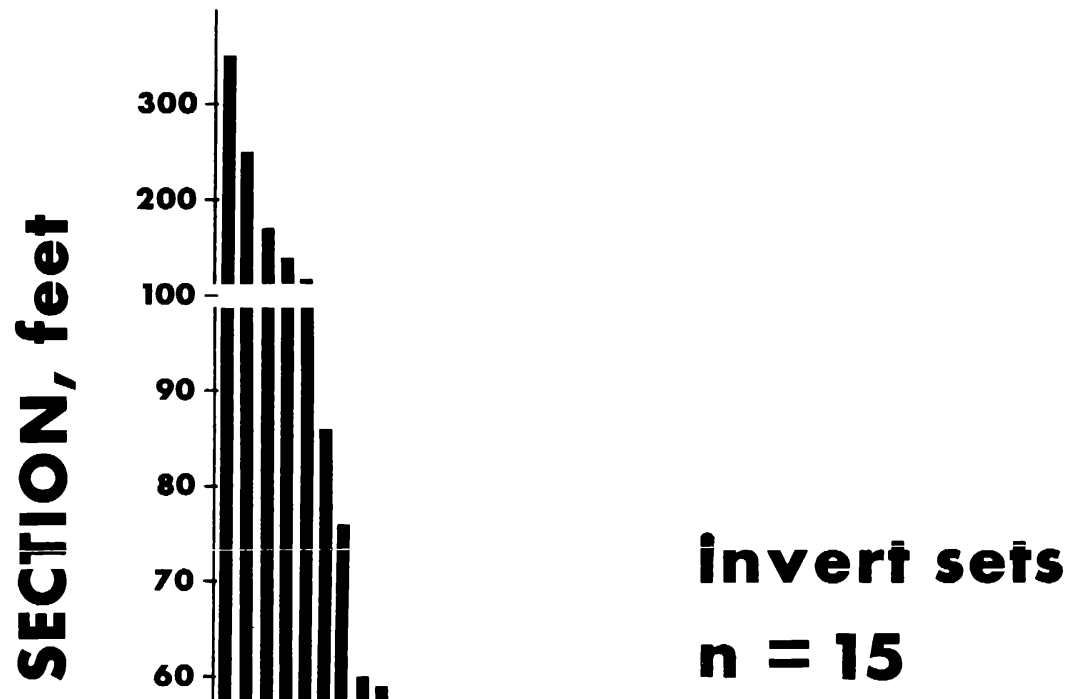

SECTIONS

FIGURE 20. - Distribution of tunnel lengths supported with invert struts. 
In using the sliding floor, difficulty was anticipated with installation of invert struts. Since these struts were installed at the face, with provision for the sliding floor to pass over the invert struts, job interference was foreseen. The problem was resolved by welding an additional 1 -foot length onto the post of both set legs with excavation below grade for strut placement. Later, longer leg posts were procured from the manufacturer.

Table 6 1ists al1 6 -inch, 8 -inch, and invert struts placed in the Flathead Tunne1.

TABLE 6. - Stee1 sets installed, F1athead Tunne1

\begin{tabular}{|c|c|c|c|c|}
\hline \multirow[b]{2}{*}{ Type of set } & \multirow[b]{2}{*}{ Set spacing, feet } & \multicolumn{3}{|c|}{ Number of sets installed } \\
\hline & & $\begin{array}{c}\text { North } \\
\text { heading }\end{array}$ & $\begin{array}{c}\text { South } \\
\text { heading }\end{array}$ & Total \\
\hline \multirow{6}{*}{$6 \mathrm{H} 20 \ldots \ldots \ldots \ldots \ldots \ldots \ldots \ldots$} & 2 & 25 & 30 & 55 \\
\hline & 3 & 14 & 7 & 21 \\
\hline & 3.5 & 0 & 3 & \\
\hline & 4 & 109 & 83 & 192 \\
\hline & 5 & 931 & 2,437 & 3,363 \\
\hline & $\ldots$ & 1,079 & 2,560 & 3,639 \\
\hline \multirow{8}{*}{$8 \mathrm{H} \quad 34.3 \ldots \ldots \ldots \ldots \ldots \ldots$} & 2 & 18 & 25 & 43 \\
\hline & 3 & 242 & 69 & 311 \\
\hline & 3.5 & 0 & 5 & \\
\hline & 4 & 621 & 453 & 1,074 \\
\hline & 4.5 & 2 & 0 & \\
\hline & 5 & 116 & 83 & 199 \\
\hline & 6 & 0 & 6 & \\
\hline & ............. & 999 & 641 & 1,640 \\
\hline \multirow[t]{7}{*}{$8 \mathrm{H} 34.3$ with invert strut..... } & 1 & 4 & 0 & 4 \\
\hline & 1.5 & 54 & 33 & 87 \\
\hline & 2 & 124 & 27 & 151 \\
\hline & 3 & 51 & 56 & 107 \\
\hline & 4 & 58 & 131 & 189 \\
\hline & 4.5 & 0 & 2 & \\
\hline & 5 & 3 & 3 & \\
\hline \multicolumn{2}{|c|}{ 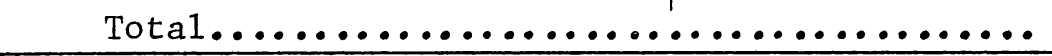 } & 294 & 252 & 546 \\
\hline
\end{tabular}

Rock-Bolt Support

Rock-bolt support during tunnel driving was dependent upon round-by-round judgements and working conditions. Nearly 27.3 percent of the total tunne1 length was rock-bolted. Rock-bolt support was authorized by mutual agreement in the field between the contractor and Corps of Engineers on a round-by-round basis. Both the contractor's supervisors and Corps of Engineers' inspectors had authorization to install supports as needed. Rock-bolt support followed section 4 of the tunnel excavation specifications (43). Specifications did not call for designated tunnel sections to require either rock bolts or steel sets. No bare rock sections were specified. Figure 21 shows typical rock structure before rock bolting. C.F. \& I. 3/4-inch-diameter rock bolts were 


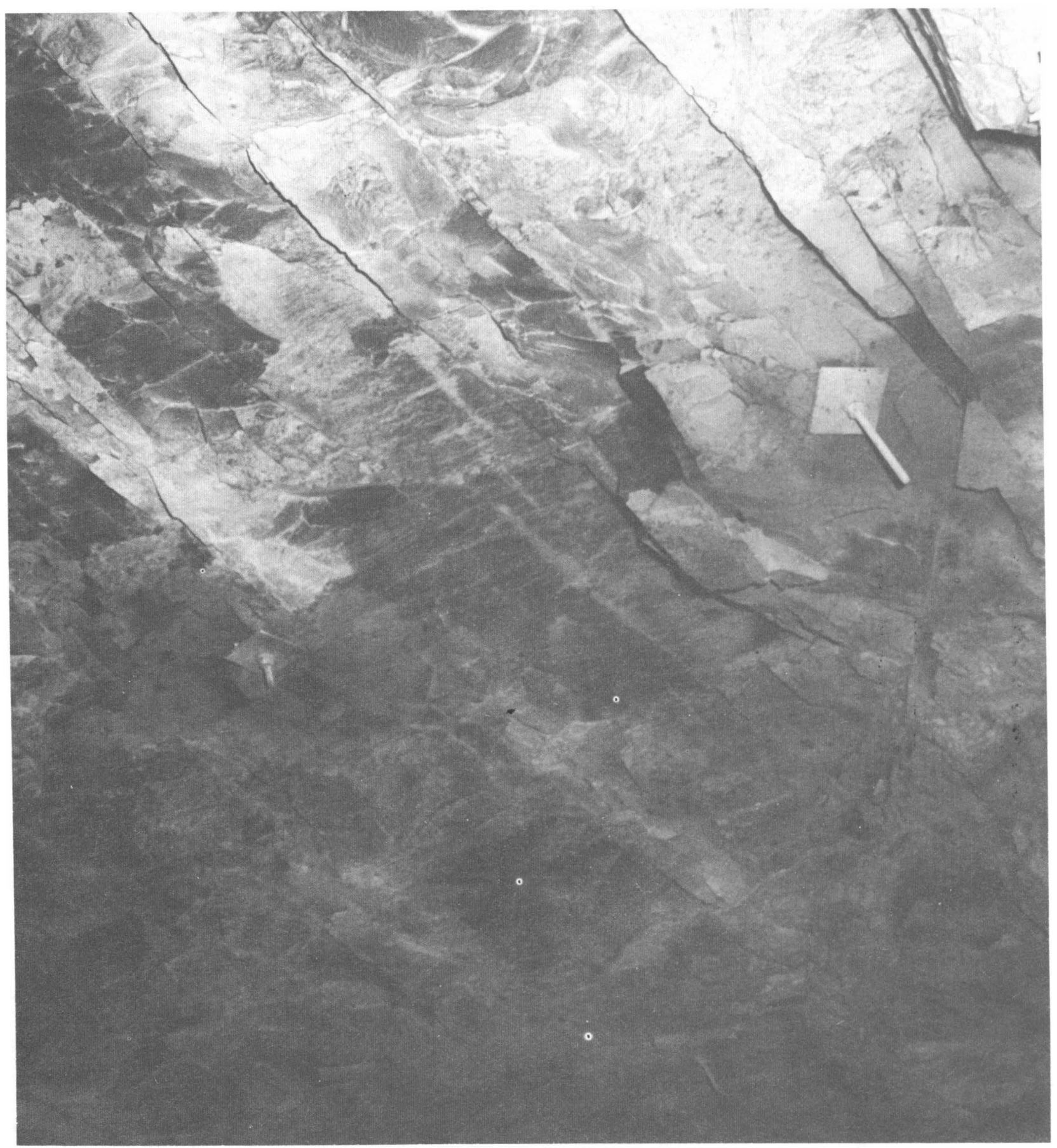

FIGURE 21. - Typical arch rock before rock bolting.

used with both ends threaded and Pattin D-5 expansion she11, and 6- by 6- by 1/4-inch bearing plate. Bolts were initially torqued to 175-foot pounds and retorqued at least once. Rock bolts over the arch were installed in conjunction with 9-gage, 2-inch mesh, nongalvanized, Realock chain-link fabric. The fencing was installed with 1 -foot continuous overlap from below the springline 
completely across the arch. Material quantities for the rock-bolt sections are shown in Appendix A.

Rock-bolt lengths ranged from 6 to 10 feet and were installed in a fixed-ring pattern across the arch. Two 6-foot bolts, two 8-foot bolts, and eight 10-foot bolts were used in each ring. The rings were spaced 4 to 6 feet apart along the tunnel length and formed an approximate square pattern. Rock bolts were placed at the face soon after excavation, but at times lagged as much as 15 feet behind the face, depending on working conditions. The 6foot bolts were placed below the springline, the 8-foot bolts straddled the springline, and all 10-foot bolts were in the arch. An additional six to seven 3-foot-1ong rock bolts (nonpay item) were placed as needed to temporarily support the chain-link mesh as the longer rock bolts were being placed. Rock-bolted sections near the portals were installed on a more random and closer pattern (estimated as about 3 feet) than sections farther along where a rock experience factor was evident. About 116 linear feet of rock bolts were calculated for each rock-bolt ring.

In the north heading, 16 sections of tunnel aggregating 5,700 feet were rock-bolted. This represented 37 percent of the tunnel driven from that heading. Two rock-bolted sections exceeded a quarter of a mile, four others were about 300 feet 1 ong, one was about 170 feet, and the remainder were in lengths of one round to 100 feet. The 1ongest section, near1y 2,000 feet, occurred shortly after good rock began at the north portal. It continued until shallow rock overburden was reached near drill hole 385 (station 3023). The next two longest sections began short1y thereafter (1,304 and 1,065 feet), as we11 as sections 338 and 285 feet 1ong. Thus, sections aggregating nearly 5,000 feet occurred near the north portal before the faulted zones were encountered. Figure 22 shows a typical rock-bolted section in the north heading. No rock-bolted sections were placed through fault zones.

Geologic mapping of these tunnel sections shows a11 the 1onger rockbolted sections are in ground described as massive, blocky to massive, or blocky. Bedding is mostly near vertical. Very few joints are shown. Some bedding spacing was described as 4 to 12 feet in mostly quartzites. These rock-bolted sections should be judged as the most exceptional of the entire project.

Approximately 18 sections of tunnel, totaling about 3,900 feet, were rock-bolted in the south heading. This represented about 20 percent of the tunnel driven from this heading. Two rock-bolted sections were nearly 800 feet in length, three sections were from 200 to 350 feet long, three sections were from 100 to 200 feet, and the remainder were about 50 to 100 feet.

Rock-bolted sections in the south heading generally were evenly spaced throughout the 19,907 feet driven from that heading. The two longest sections, each about 800 feet, along with al1 the six rock-bolted lengths of 100 to 350 feet, occurred under the deeper overburden on the flank of E1k Mountain. Geologic mapping showed all these sections to occur in massive to moderately fractured rock which was nearly horizontally bedded, but having near-vertical jointing. 


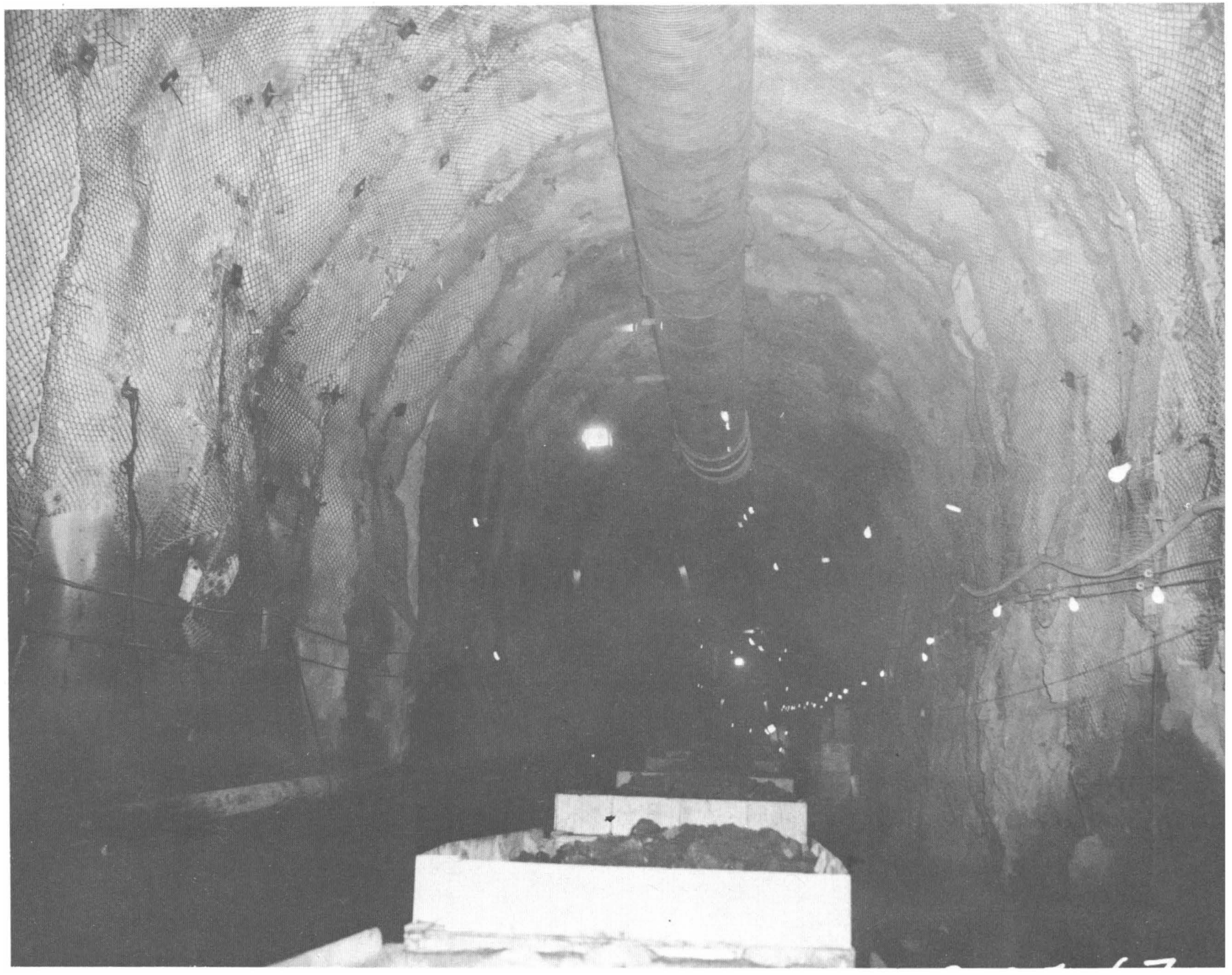

FIGURE 22. - Typical rock-bolted section in north heading.

No rock-bolted sections of any length were placed in the E1k Mountain Fault zone. Figure 23 shows the individual lengths of tunnel supported with rock bolts. The 27.3 percent of tunnel actually carried by rock bolts is somewhat less than the 40 percent predicted.

\section{Special Problems (Tunne1)}

A gradual change from nearly horizontal bedded rock to highly fractured rock occurred in the 1,600 feet which preceded the only instance of rock failure in the Flathead Tunnel. Support throughout this ground was 6-inch sets on 5-foot spacing. Even a 42-foot length of rock-bolt support was used. An abrupt change in ground conditions occurred when the E1k Mountain Fault zone was penetrated in the right, or east, rib just above the invert. Fault zone material was described as intensely shattered, gougy, wet, loose, and highly broken rock. Eight-inch steel sets on 5-foot centers were begun at the fault, but some 6 -inch sets were used in mixed support beyond the fault until the rockfall occurred. Heading progress the 2 days prior to collapse was 56 and 50 feet, respectively. 


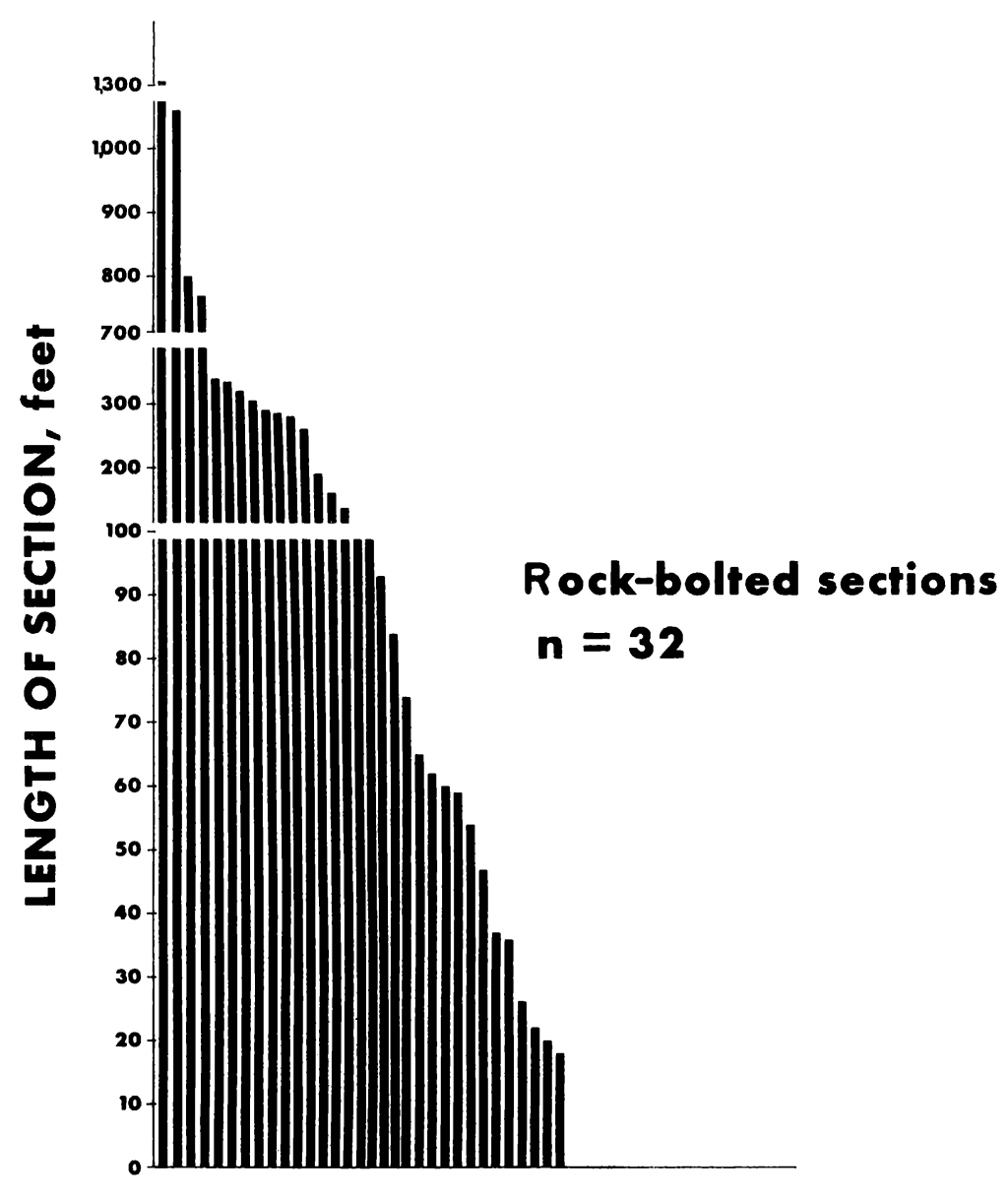

SECTIONS

FIGURE 23. - Distribution of rock-bolt support.
The E1k Mountain Fault was projected from surface details, as described previous1y in the geologic sections of this report. Overburden was about 1,130 feet. Bedding dip at the fault intersection was about $15^{\circ}$ to the west. As the tunnel heading progressed updip through the fault, the fault continued to enlarge from the invert upward to the crown. Bedding immediately above the fault was noted to be dis tinctly overturned on drag folds. At 264 feet before the collapse, the entire face was in the fault zone. The fault gouge and shattered rock was about 20 to 30 feet thick when penetrated. Only slight water seepage occurred. The fault continued upward into the crown, but the rock below, in the fault foot wal1, was well-fractured for nearly the next 250 feet of tunnel progress, until approximately horizontal bedded rock was again encountered. Many

prominent vertical joints were also encountered along this zone.

The ground failure occurred during mucking operations at about 1:00 p.m., September 18, 1967. First evidence of impending failure noted by the contractor's personnel was that rock was unaccountably peeling off the face. Certain evidence was inward movement of about 8 inches at the east footblock of the first 6 -inch set immediately behind the face. The operating crew then moved the mucking machine and jumbo to the rear while lateral movement from the east continued to progressively collapse fifteen 6 -inch steel sets on 5 -foot centers across a length of 75 feet. Figure 24 shows a view into the collapsed tunnel section. No injuries occurred and no equipment was damaged. Set loading was lateral, mostly deforming the leg posts, which were not designed for lateral loading. Several posts had torn welds on the end plates. The horizontal struts shown in figure 24 were leg posts from 8 -inch sets randomly placed as needed; about 12 were used across the fallout. 


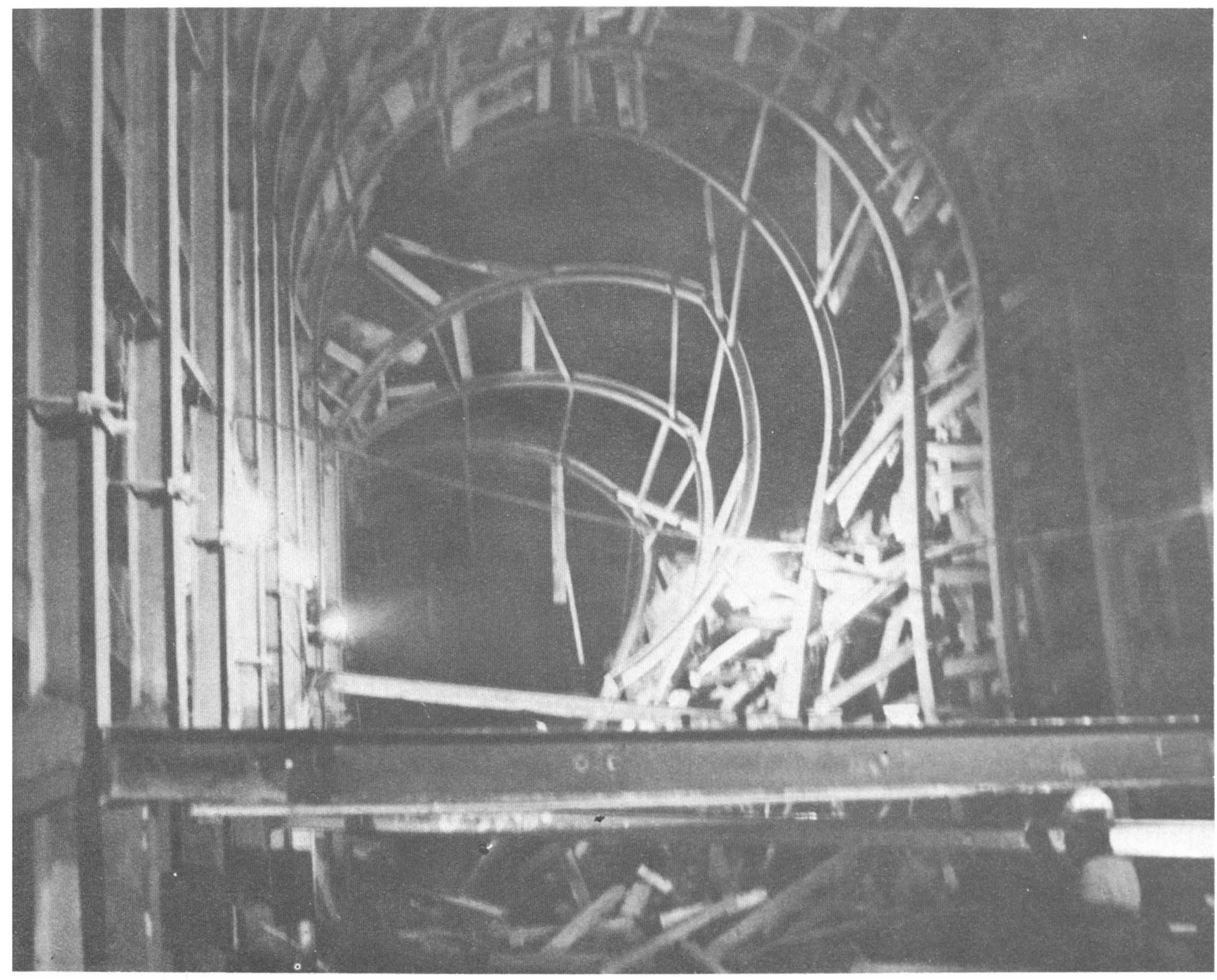

FIGURE 24. - Collapsed tunnel supports.

No progress could be made for the following 10 days until cleanup and repairs were completed ( $f i g .25$ ). This included a concrete floor slab, as shown. Replacement steel sets were 8-inch sets on 2-1/2-foot centers through the collapse zone. Straight-1eg posts from 6 -inch sets were embedded in the concrete floor slab. Remaining steel sets not affected were not removed. Much of the fault zone continued to be carried by 6 -inch sets on 5 -foot centers. Regular tunnel progress then continued at about 35 feet per day for the next few days with 8-inch sets on 3- and 4-foot centers used for the next 400 feet until the E1k Mountain Fault zone was fully crossed.

Cause of the lateral slippage of rock resulting in collapse was not definitely established (36). Tunnel alinement compounded with intersections of prominent vertical joints, along with minor faulting parallel to the Elk Mountain Fault, which somewhat coincided with the natural bedding and orientation of joints dipping $30^{\circ}$ east, ended to produce freely bounded masses of rock. This resulted in vertical loads with large lateral components 


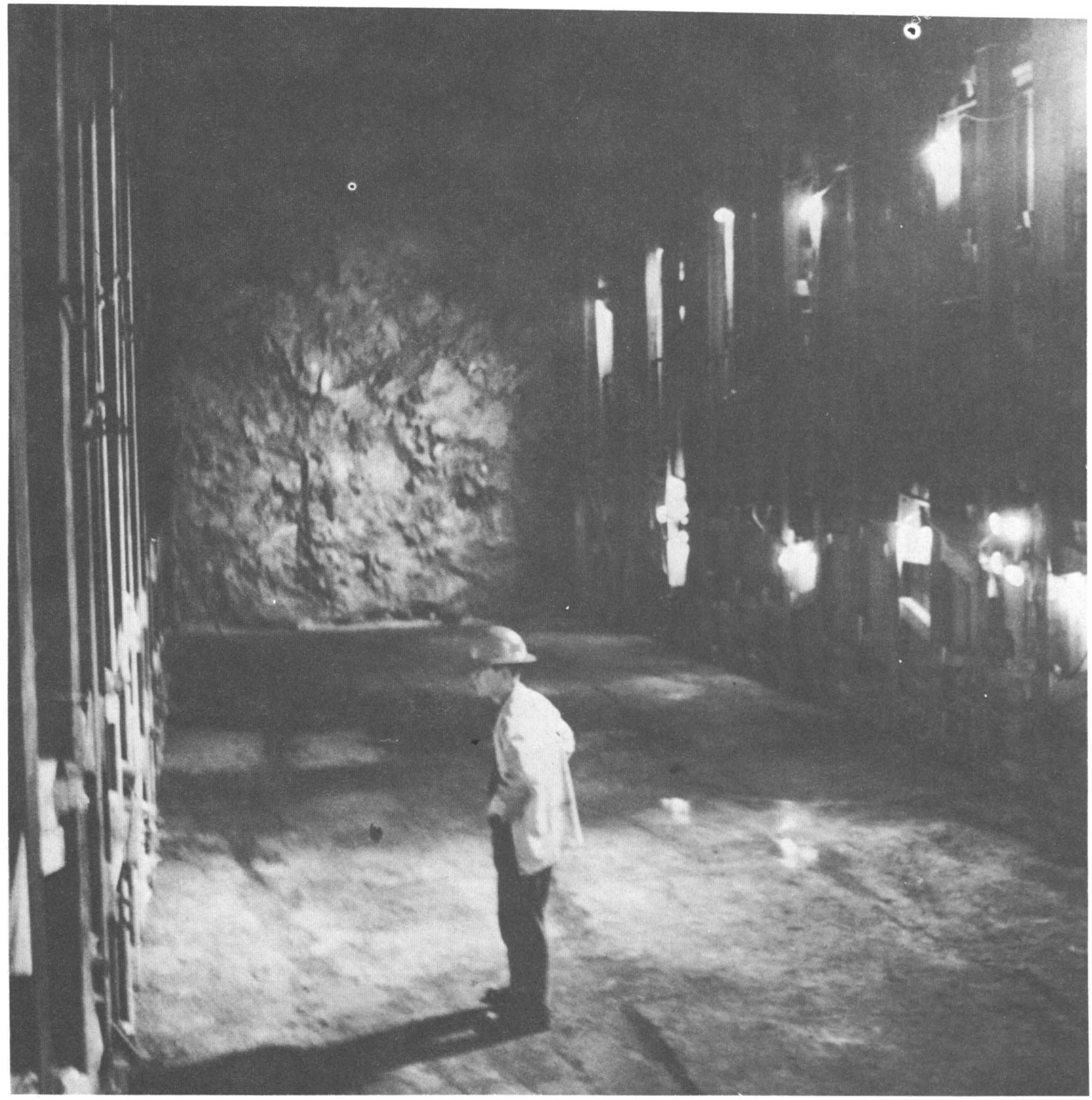

FIGURE 25. - Completed repair of rockfall section.

transferred onto the east rib. Figure 26 shows 10 cross sections through the collapse zone. Note that the depth of fallout was about one tunnel radius for a length of about 20 feet.

The estimated amount of fallout was 600 cubic yards. Prior rock conditions encountered showed no indication that undue side pressures existed and that the use of previously used sets would not adequately support the rock. The physical appearance of the fallout zone indicated that loads developed rapidly along the zone of weakness. 

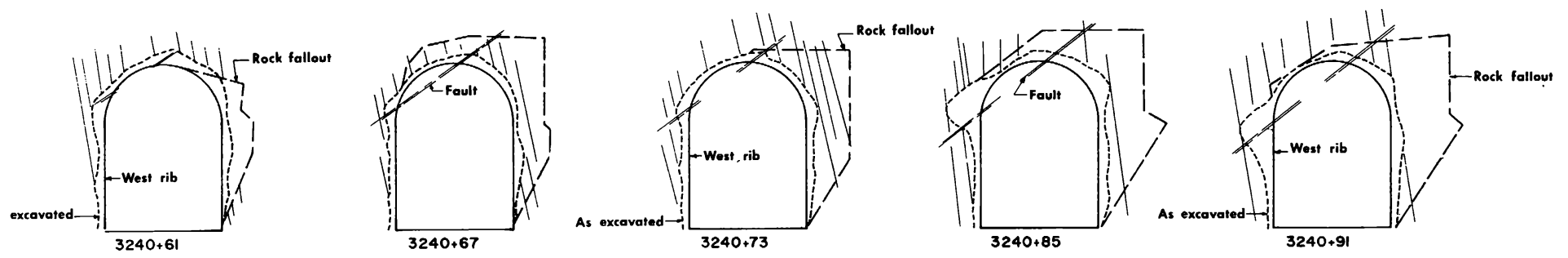

-Direction of tunnel advance

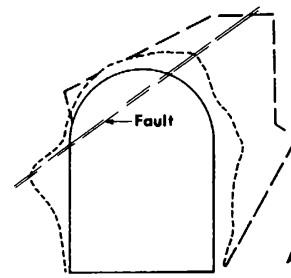

$3240+97$
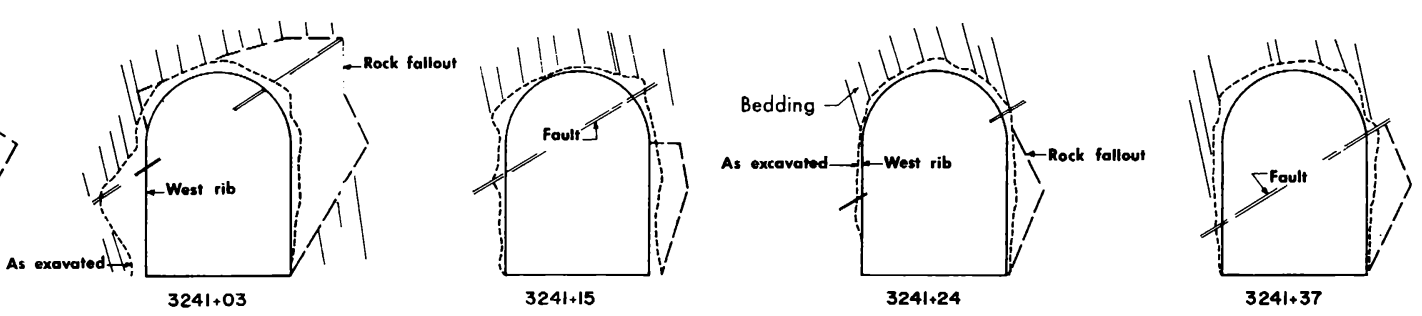

FIGURE 26. - Cross sections of tunnel collapse zone. 
Special Problems (Porta1)

Approximately between stations 2994 and 2996 (or about 60 feet south of the north portal location) an earthslide condition developed along a cut slope on Burrow's Creek. The bedrock surface had been interpolated from several dri11 holes previously drilled near the north portal. A substantial gorge to a depth of at least 22 feet below the construction tunnel grade was revealed to exist in the bedrock. This gorge had been refilled with watersaturated clay, silt, cobbly gravel, and surface boulders up to 2 feet in diameter.

The tunnel invert grade throughout this section required a cut section ranging from a few feet up to approximately 100 feet deep with side slopes on a 15-percent grade. It was from these exposed and weakened slope conditions that Burrow's Creek slide developed from a relatively insignificant drainage channel by that name, less than $1 / 2$ mile long, with 900 acres drainage, which traversed the tunnel centerline at right angles. Construction generally aggravated the slide condition and hindered stabilization of the slide.

Portal excavation had begun in August 1966 with slopes cut to $1-1 / 2: 1$ down to tunnel grade. In September 1966, slope movement was first observed that extended 220 feet upslope (to the west) from tunnel centerline. The slopes were subsequently cut back to 3:1 that fall. Slide activity was dormant during the winter. However, in the spring of 1967, the slide resumed activity and had extended about 900 feet upslope from the centerline by May 16, 1967. During this time, parallel rows of sheet piles were driven to refusal on both sides of the tunnel centerline. The slide material between the piling was then excavated down to the original tunnel grade. In succeeding weeks this attempt proved inadequate as the continued slide movment partially buckled and material overflowed the west piling curtain. At the peak of slide activity, it was estimated that an excess of 25,000 cubic yards of material was involved (fig. 27).

In late June 1967, the assistance of a soils consultant was obtained to provide recommendations for stabilization of the slide. The design rationale selected was to effectively isolate the tunnel from the slide. Tunnel construction could accommodate some lateral movement in the fill that would allow time for the slide to restabilize before final lining was installed. Also, the gravel backfill provided in the foundation core would allow free drainage around the structure. This work was to be followed by a massive backfill to approximate the original ground surface.

An extensive system of 22 horizontal drainage we11s with slotted plastic liners was driven to the bedrock surface across the core of the slide during the summer of 1967. These drains produced temporary high initial water flows but substantially less than expected; half the holes quickly became dry. This drainage was in addition to previous drilling and a determined program of surface drainage. Sixteen exploratory holes had been drilled in the slide area during October and November 1966. Fourteen additional churn-drill holes were drilled during February 1967. They were all placed near the head of the slide. Selected holes were test pumped in March and April 1967: four of the 


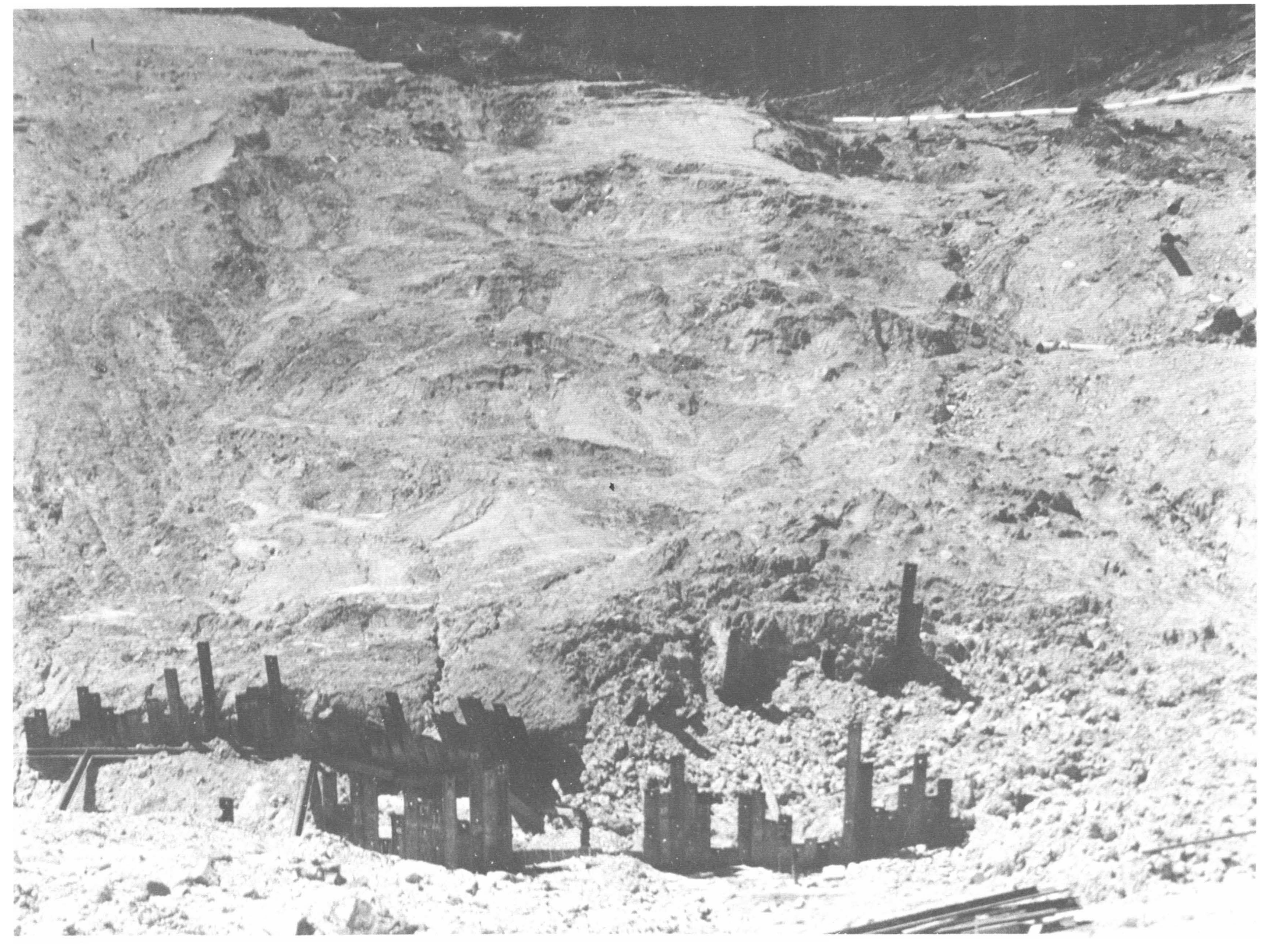

FIGURE 27. - Burrows Creek slide. 
exploratory and 11 of the churn-drill holes, respectively. The peak yield from al1 wells during these tests reached 2,300 gallons per day, with two holes having flows in excess of 500 gallons per day.

A 150 -foot length of tunnel centerline section was selected for extensive remedial effort. Additional piling of $z-38$ sections were driven just outside the previously buckled sheet piling and reinforced with a grid system of 27 WF 84 shoring supports and 14 WF 111 struts, constructed between the piles. Slide material between the $z$ piling was then excavated to bedrock and seven 3-1/2 - by 28-foot -wide rectangular reinforced concrete piers were placed to bedrock on 12-1/2-foot centers as excavation was completed (progressively from north to south across the slide). The excavation between piers was then backfilled with gravel. This work and general cleanup of the slide were completed November 17, 1967. Measured quantities of earth removed from the slide were computed as 34,230 cubic yards.

Overlying this foundation, a continuous slab of structural concrete 3-1/2 feet thick and containing embedded 8 - by 8 -foot $M 34.3$ tunnel rib sections at 18 -inch centers was placed throughout the 100 -foot central span. End structures for this span consisted of massive lean concrete pours of 40 and 50 feet in length, respectively, at the north and south terminus of the slide repair. Thus, the entire length of tunnel supported by this remedial effort was 190 feet.

The slide area was continually monitored during the remedial work with four piezometer cells and six slope indicator instruments to observe movement and pore pressures during consolidation of the slide and backfill material.

Horseshoe steel sets were then erected on the existing steel struts embedded in the floor of the slab and solidly timber-1agged throughout. Bracing was also installed between the $z$ piles and lagging. Concrete drainage pipe of 15-inch-diameter perforated design and gravel fill were placed in the annular space.

Backfill over the remedial section of Burrows Creek began in February 1968, at which time instrumentation monitoring of the slide activity indicated little or no movement. Backfilling was done approximately to the springline of the tunnel sets. During the spring of 1968, the slide became active and some undetermined lateral movement occurred in the slide. However, a11 measurements within the slide indicated insignificant movement after about September $1,1968$.

Upon completion of final backfilling with approximately 265,000 cubic yards of material and apparent stability of the slide, the contractor was able to complete the tunne1 without interference and to maintain the original completion schedule for concrete lining the tunne1. A simplified presentation of the remedial work completed at the Burrows Creek slide is shown in figure 28. The figure is looking south, so that west is on the right. Note the extensive 


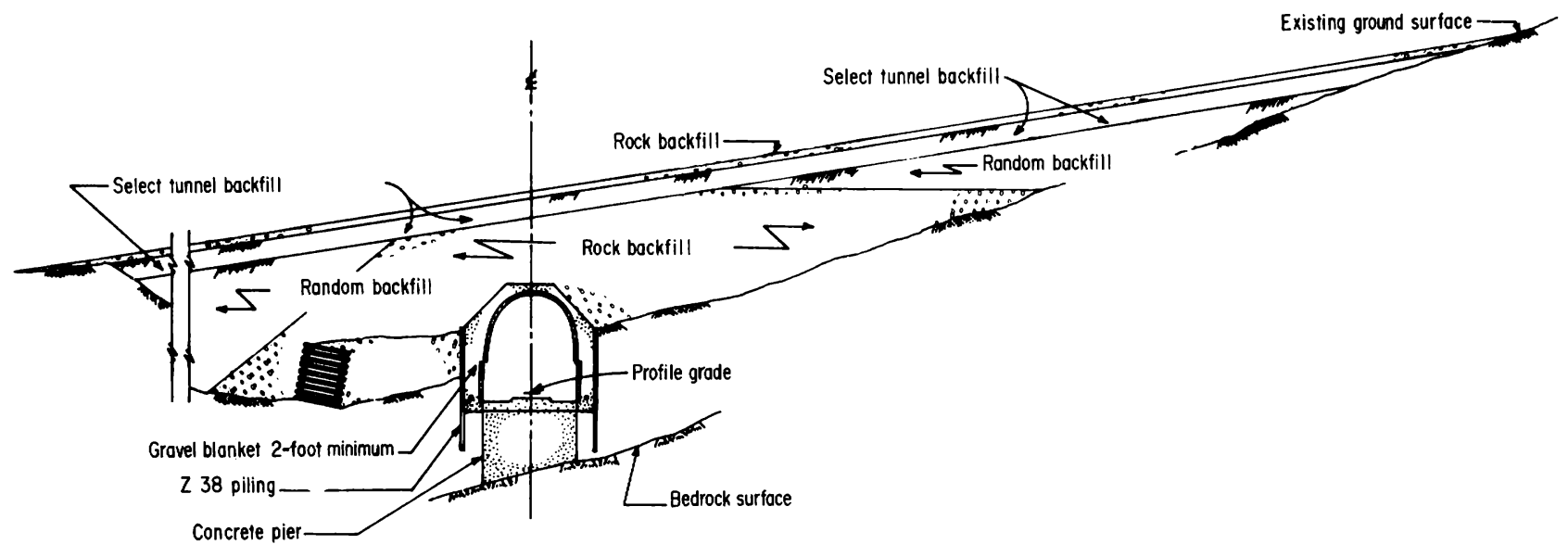

FIGURE 28. - Burrows Creek backfill section.

drainage provisions. Figure 29 shows typical construction of the concrete cutand-cover section. Note the $z$ piling in the foreground.

Permanent Support

Design Criteria

Permanent support included two types of concrete structures: cut-andcover portal structures and underground tunnel sections.

The tunnel section concrete lining was designed as a monolithic structure to carry rock loading from all types of rock conditions encountered along the tunnel. Nominal concrete strength was 3,500 psi (28 days) with a mimimum lining thickness of 18 inches to the A-1ine. Concrete payment was based on placement to the B-1ine ( 6 inches beyond the A-1ine). Type II, low-alkali cement, was used. Concrete tunnel structures were assumed to carry vertical rock loads uniformly across the arch. These loads were further assumed to be transferred as axial loads onto the sidewalls. Sidewalls were assumed as fixed ended columns without side deflection. Calculated stresses were compressive and low.

The presence of steel supports integrally cast in the concrete lining was not considered in the analysis of the lining. Steel sets carrying rock loads before concreteplacement were assumed to continue to carry rock loads after concreting. Steel sets, however, were assumed to carry all tensilebending moments developed in the integral concrete-steel liner. A continuous curtain of reinforcing steel was placed with No. 5 bars at 2 feet, longitudinally; and No. 6 bars at 1 foot, transversely. Only in one section of tunnel (through nearly vertically dipping faulted rock at the beginning of the east branch of Elk Mountain Fault) were No. 6 bars increased to No. 11 bars at 8 inches.

An extensive water-drainage system was incorporated into the initial tunnei lining design but was substantially decreased because of less than anticipated ground-water inflow encountered during excavation. A typical 


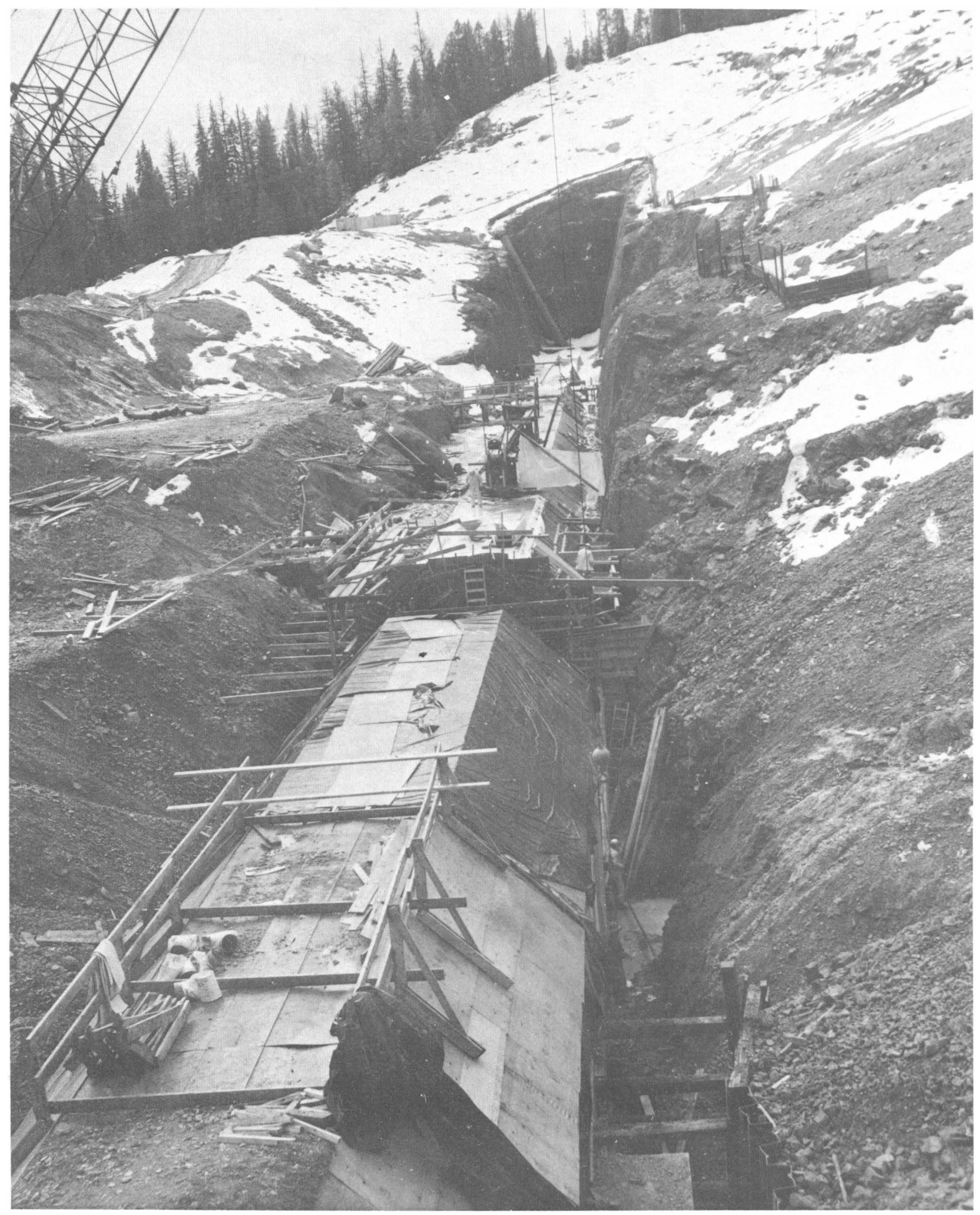

FIGURE 29. - Cut-and-cover construction, north portal. 


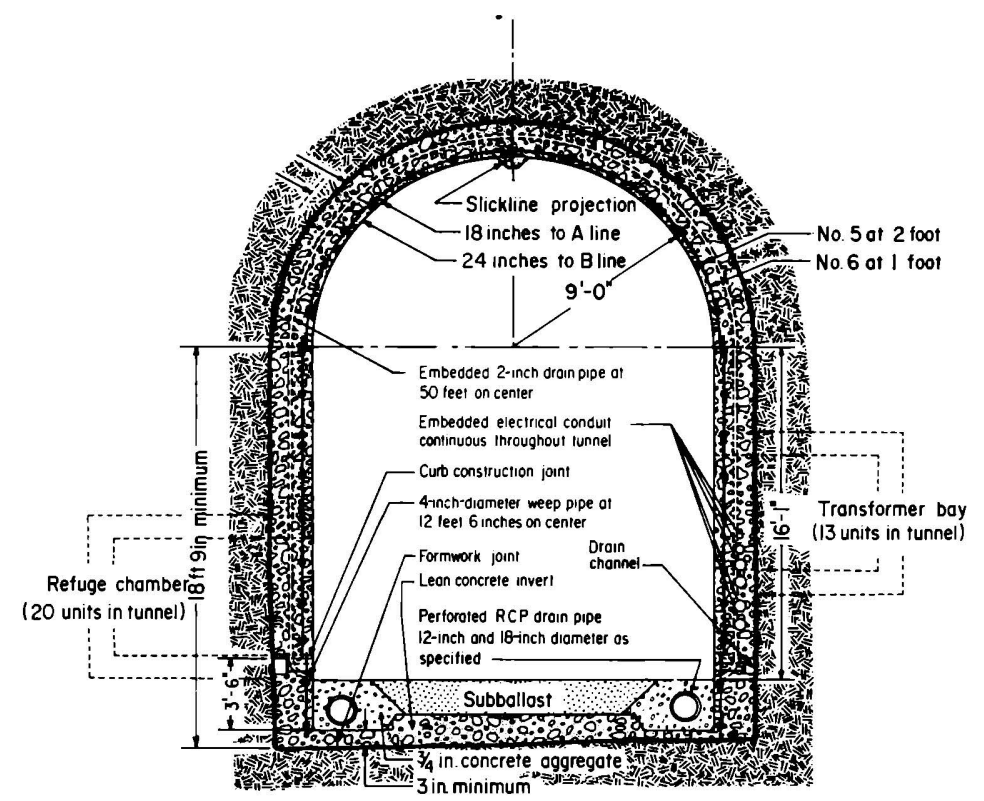

FIGURE 30. - Typical concrete-lined tunnel section.

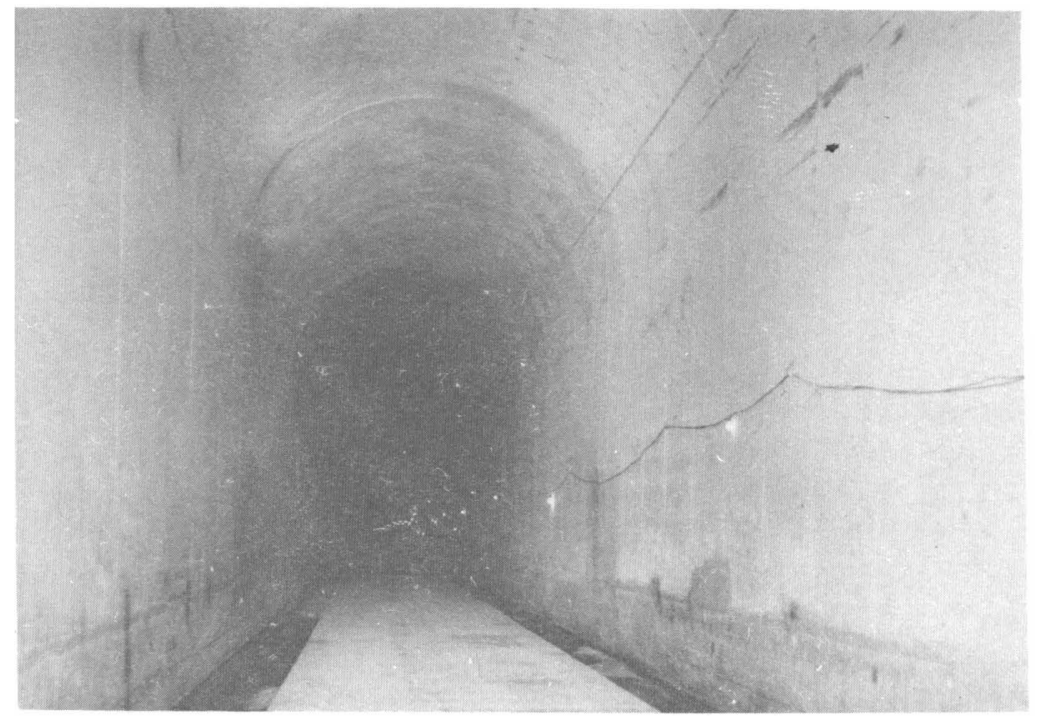

FIGURE 31. - Completed concrete-lined tunnel section. concrete-lined tunnel section is shown in figure 30 . Typical completed concrete tunnel liner section is shown in figure 31 , but lacking the sub-ballast and railway trackage.

Three types of cut-andcover sections were designed. Where rock was in direct contact with the concrete walls to a height of less than 9 feet, the section was designed as a two-hinged arch, the hinges being located at the bottom of the wall. Where rock was in contact with concrete to a height of more than 9 feet, the section was designed as a hingeless arch. Fixity was assumed at the highest point of rock contact. Where the cut-and-cover section had a concrete bottom, the section was designed as a horseshoe-shaped conduit. The arch was designed as a symmetrical arch for sections with a bottom and for rock sections above the springline (including tunnel sections previously described). Settlement of backfill below the springline was considered. Active earth pressures were computed using Rankine's theory.

Basic design criteria and allowable stresses were as recommended in design manuals of the Corps of Engineers and American Railway Engineering Association $(2,3)$. Other specifications were used as applicable. Some allowable material stresses are as follows: 


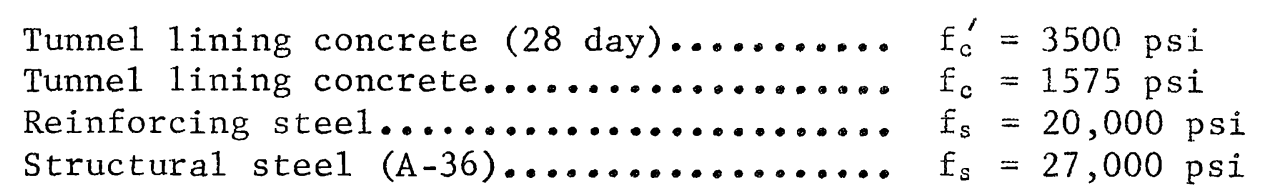

Design and Construction Problems

The following design and construction problems developed during progress of the project, mainly in placement of permanent support. They were considered of such scope that (1) changes from initial design were necessary or (2) a decision had to be made related to progress of the work. Ordinary problems affecting only equipment or construction procedures are not included.

Concrete operations through one or more winter seasons were obvious. Rate of placement, job schedules, and potential problems with the overall concrete-1ining operations were assessed as equal to ground conditions in comparing the magnitude of possible difficulties (39). Winterizing the complete concrete plant and aggregate facility was therefore mandatory and these installations were designed accordingly, as will be described in the section on concrete control. Job schedules were then oriented so that all underground concrete tunnel lining would be done in the winter season. This required an interval of time during which both tunnel driving and invert concreting were done concurrently.

The design of the concrete tunnel lining formwork and the use of available equipment required construction of concrete curbs prior to placing wall and arch concrete. It was the intent of the contractor to utilize rock bolts to anchor the curb formwork and later the wall and arch formwork. Calculations indicated that rock-bolt loads might exceed 50,000 pounds in tension with 3-foot rock-bolt spacing. Rock-bolt pullout tests (described later in the section on rock bolts) were unfavorable to the rock-bolt plan as a highly reliable system. An alternate method of securing the curb formwork, which in turn affected the manner of restraining the wall and arch formwork, was deemed necessary. This construction change is described in the section on curb concrete.

Attention was directed towards utilizing the invert concrete shoulder as a bearing surface for wall and arch form blocking. Design specified a $45^{\circ}$ sloping shoulder, but this appeared inadequate to provide sufficient horizontal thrust restrain without auxiliary anchor bolts. In order to obtain an adequate bearing surface capable of withstanding sidewall and arch formwork loads, the invert shoulder slope was changed to approximately $75^{\circ}$, as shown in figure 30. The decision was then made to provide all support for wall and arch formwork with this revised invert concrete section. Only anchorage for curb forms was provided by rock bolts (fig. 34).

A 6-inch-deep keyway at the base of the tunnel ribs was specified in the original invert design through all tunnel lengths supported with rock bolts or steel sets without invert struts. Since drilling and blasting techniques would be required for this keyway, it was not considered the most expedient method for an operation geared to high rates of production. 
Excavation and evaluation of such a keyway would have to await complete cleanup of the tunnel. Additional keyway excavation would be time consuming and was thought 1 ikely to result in delays to concrete operations.

The original tunnel invert section further contained drainage channels at the floor grade on both tunnel rib walls. Only 3 inches were specified between the maximum and minimum excavation lines in the invert section containing the railroad ballast. Any excavation below the B-1ine was to be replaced with lean concrete up to the B-line, but no higher than the A-line. In the process of tunnel excavation, it was apparent that any attempt to rigidly maintain these tolerances would inhibit schedules. Achieving consistent results was also highly improbable. Hence, no attempt was made to excavate the center portion of the invert to the original tolerance. A poured invert was considered to be the most practical means of overcoming this impediment. The alternate design finally adopted provided a 3 -inch minimum thickness of lean concrete in the invert (fig. 30).

Initially, construction or excavation for several of these design features was scheduled after "holing through" of the tunnel was completed. As tunnel excavation progressed toward completion, opinion was expressed as to concurrent scheduling of preliminary tunnel lining work. In view of possible adverse winter operations, if critical job completion schedules were not explicitly followed, as well as limiting access and services for other operations, it was decided to schedule excavation of the refuge and transformer openings concurrent with tunnel excavation and to begin placement of curb concrete when 15,228 feet of tunnel remained to be excavated.

Original tunnel concrete lining design required installation of vertical contraction joints with waterstops at 50-foot intervals. This design was predicated upon pouring techniques within the state-of-the-art, but would have eliminated employment of continuous inline placing technique. The entire length of lining also contained a curtain of reinforcement steel within 2-1/2 inches of the formed concrete surface. Adequate clearance to accommodate a slickline for pumping concrete over the top of the forms was not provided in the originaldesign. This point was a part of the value engineering proposal described in the next section.

\section{Value Engineering}

A value engineering clause was included in the contract. This clause allowed the contractor to initiate cost-reduction proposals that would result in contract changes, but would not adversely affect the structure. A value engineering proposal, based on some of the previous design and construction problems, specifically the continuity of concrete placing operations, was submitted by the contractor.

Meetings were initiated by the contractor regarding design changes to permit continuous placement of tunnel lining concrete and the elimination of regularly spaced contraction joints. Personnel from the Corps of Engineers, Burlington Northern, and Walsh-Groves attended a series of meetings to discuss the merits and faults of continuous placing techniques as applied to the 
Flathead Tunne1. Special concern was expressed on cold joints between succeeding concrete pours. The problem of shrinkage cracks in a lining with few contraction joints was especially debated. Agreement was reached that shrinkage cracks could not be eliminated with any practical scheme. Assurance was given that workable concrete pours would be maintained by close coordination of a concrete pump placing arch concrete while a conveyor placed concrete up to the springline.

The scope of agreed design changes are as follows:

1. The location of vertical contraction joint waterstops was changed from 50-foot centers to joints only at breaks in the continuous 1 ining, and these would be at the end of a weekly pouring schedule.

2. The concrete-1ined tunnel section was necessarily revised for continuous lining to include a projection 4 inches high along the centerline of the arch (fig. 30). The forming method required a trough in the concrete forms which supported the concrete slickline to provide clearance beneath the reinforcement steel curtain. As the trough filled with concrete, the projection resulted. To offset the vertical clearance lost due to this projection, the overall invert grade was lowered 4 inches. The vertical curves in the railroad grade outside each portal were consequently adjusted.

3. The continuous-pour concept changed reinforcement steel quantities. The revision resulted in a continuous curtain rather than in breaks at every 50 -foot contraction joint, as originally planned. However, reinforcement breaks were required at joints in the continuous pour.

4. Other hardware items embedded along the arch centerline were simply offset from the 4-inch projection.

The contractor's value engineering proposal was accepted by the Corps of Engineers and the owner. Construction material, time, and costs were then evaluated. A savings of about $\$ 790,000$, or 8 percent of the approximate $\$ 10,000,000$ for the entire concrete-lining portion, was realized. This substantial savings was equally shared between the Government and the contractor.

\section{Concrete Contro1}

Scheduling of concrete operations required batch plant facilities at each portal. Further planning, to the time the batch,plants were actually erected, indicated that approximately half of both curb and invert concrete would be batched at each plant with all of the wall and arch concrete to come from the north portal plant (by haulage through the excavated tunnel). Each batch plant would be used for concrete required for its respective cut-and-cover portal section.

The north portal concrete plant was especially designed to allow concrete placement during winter months. A reclaim tunnel beneath the aggregate yards was installed on weather considerations as was the waterproof nylon tent-type fabric enclosing the stacking conveyors and the three aggregate storage 
stockpiles. This enclosure used the guy cables between the aggregate conveyor support towers and the ground anchors to support the tent arrangement over each of the three stockpiles. Although snow and ice conditions necessitated constant surveillance, and labor costs for operation were substantial, the system proved workable. A 50-hp propane-fired boiler was used to supply steam to sand drawpoints at the north portal. The boiler was also utilized to heat water in a 750-gallon tank for temperature-controlled batching water. A 25-hp propane-fired boiler was used at the south portal. Steam was used only in storage bins, in transfer bins, for heating water, and as required for direct application to frozen material. Propane-fired sand dryers were added to the winterized facilities at the north portal during the winter of 1968-69, as heat from an enclosed steam system would not sufficiently penetrate the sand to prevent freezing. Essentially, all sand needed during cold weather was fed through the dryer prior to stockpiling.

The batch feed conveyors, weigh batcher, and rescreen assembly, the boiler, hot andcold water storage tanks, and the concrete mixers were a11 enclosed in plywood structures at the north portal. The batch plant facility and rescreen structure only were enclosed with plywood at the south portal.

The batch plant system at the north portal consisted of a low-profile Noble mode1 100-A utilizing two 2-cubic-yard tilting mixers with 5-cubic-yard aggregate and cement weigh batchers. A 45-ton three-compartment aggregate storage bin and two 800-barrel bulk cement silos provided charging to weigh batchers. Automatic batching of cement and aggregate was aided by a 125cubic-foot wet mix holding hopper and a Dial-A-Batch electronic control system. A vibrating rescreen mounted over the weigh batcher (immediately above the aggregate storage bins) rescreened al1 3/4-inch and 1-1/2-inch aggregate immediately prior to incorporation into the concrete mix. Figure 32 shows the winterized north portal concrete batch plant. Approximately 275,000 cubic yards of concrete was ultimately batched at this north portal plant.

The south portal concrete plant and aggregate handling facility was erected with the intent of batching only small daily quantities of about 75 cubic yards during extreme winter conditions. Basically, the south portal batch plant was comparable to the north portal facility. A change was made, however: the weigh batcher and four 25-cubic-yard aggregate storage bins were stacked immediately above the two 2-cubic-yard tilting mixtures. Both the 3/4-inch and 1-1/2-inch concrete aggregates were rescreened over a vibrating screen prior to being conveyed into storage bins. Approximately 30,000 cubic yards of concrete was ultimately batched at the south portal point.

The aggregate stacking facility installed at the north portal was capable of stockpiling about 60,000 tons of aggregate in three separate piles. The 8-foot-diameter, 430 -foot-long reclaim tunnel with $3 / 16$-inch 1 iner plate and reinforced with 4 -inch $W F$ beams on 5-foot, 4-inch centers was constructed under the aggregate stockpiles. Four drawpoints were installed for each of the three aggregates used--1-1/2 inch, 3/4 inch, and sand. At each of the four sand drawpoints, the two drawpoints of the $3 / 4$ and $1-1 / 2$-inch aggregate sizes, closed-circuit steam grids were used (1ive steam was not allowed). A 


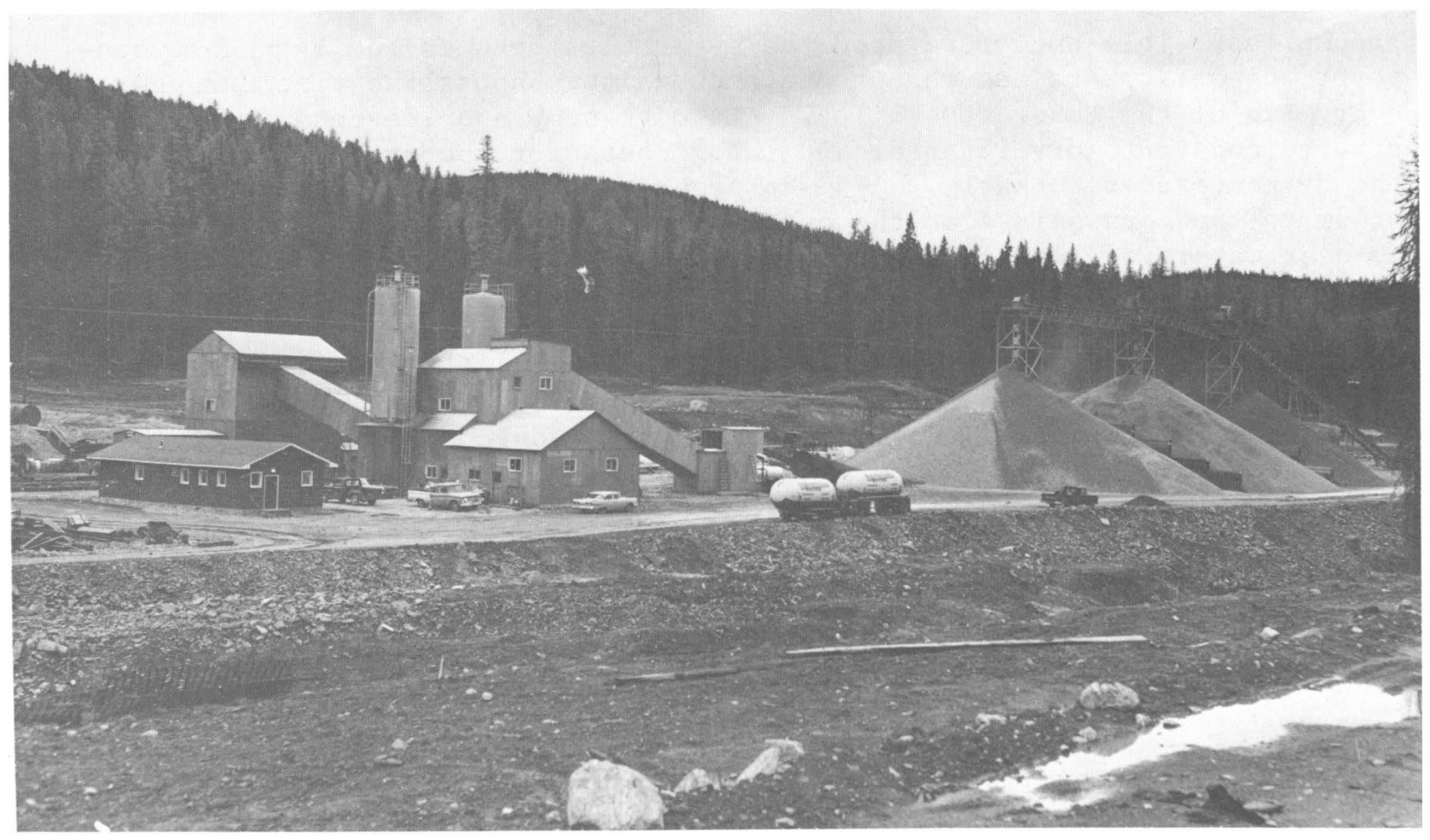

FIGURE 32. - North portal concrete batching plant.

30 -inch feed conveyor ran the length of the reclaim tunnel and supplied aggregate quantities on demand to the rescreen and batching facilities. Rock ladders for reducing breakage were installed in both the 3/4- and 1-1/2-inch conveyor support towers.

At the south portal, a radial stacking conveyor was used to stockpile approximately 20,000 tons of aggregate (in the three sizes used). No weatherproofing was provided for the stacking system.

Concrete aggregates were obtained approximately 36 miles from jobsite from a private source known as the Curtis Pit, located near Rexford, Mont. This pit was selected over several others, which were all closer, because local roads were inadequate between the aggregate source and the tunnel site. Daily replenishment of aggregate stockpiles was accomplished without difficulty, except during some days of extreme cold and during the spring, when road haulage on State highways was not permitted.

Total aggregate delivered was approximately 101,700 tons of coarse aggregate (1-1/2 inch), 152,600 tons of aggregate (3/4 inch), and 169,500 tons of fine aggregate (sand). Total portland cement used was 397,500 barre1s. Bulk cement was hauled by railroad to the Trego siding and unloaded into a 1,200-barrel storage silo. An additional railroad cement car to truck loading facility was also installed during construction. Cement was trucked to the jobsite batching plants. Figure 33 is an aerial view of operations at the 


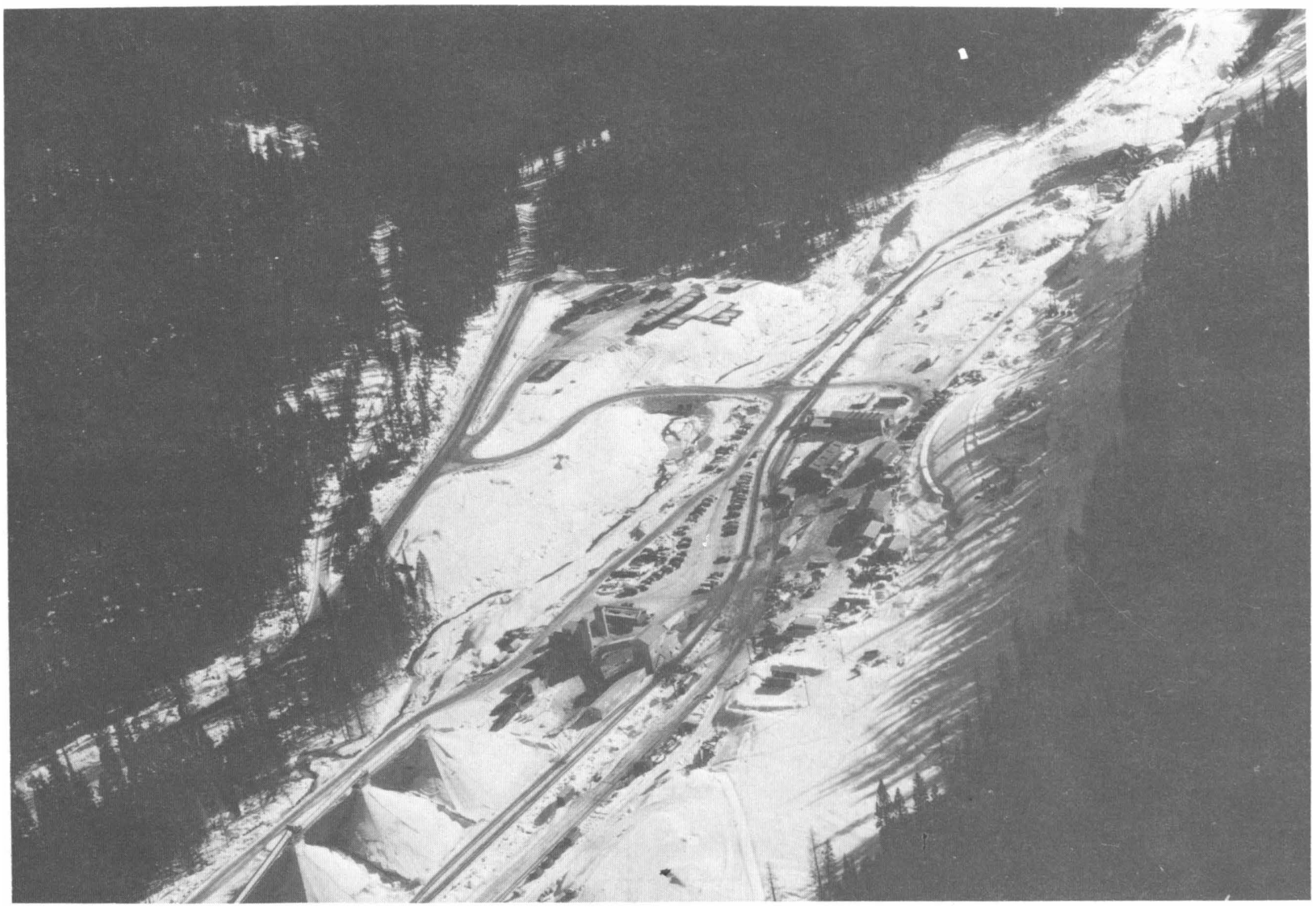

FIGURE 33. - Aerial view of north portal.

north portal during the height of activity. The north portal is at the upper right and the concrete plant at the lower left.

\section{Tunne1 Concrete}

\section{Curb Concrete}

Prior to complete concrete tunnel lining, placement of a concrete curb approximately 4 feet high was required. This curbing operation proceeded concurrently with tunnel excavation beginning August 25, 1967, when 15,228 feet of tunnel remained to be excavated. Drilling of rock-bolt holes to anchor the curb form (in areas of tunnel not supported with steel sets) had begun earlier. These same rock bolts were to be 1 ater used for wall and arch formwork also. However, as discussed previously in the section on design construction problems, this concept was discarded.

Curb formwork is shown in figure 34. Note the alinement system and tiedown method. The curb formwork was erected as shown, with 25 -foot sections being moved ahead and reset as a unit. Setting forms and placing curb concrete was conducted from a California switch assembly that was moved daily (or as required) for continual concrete placement. 


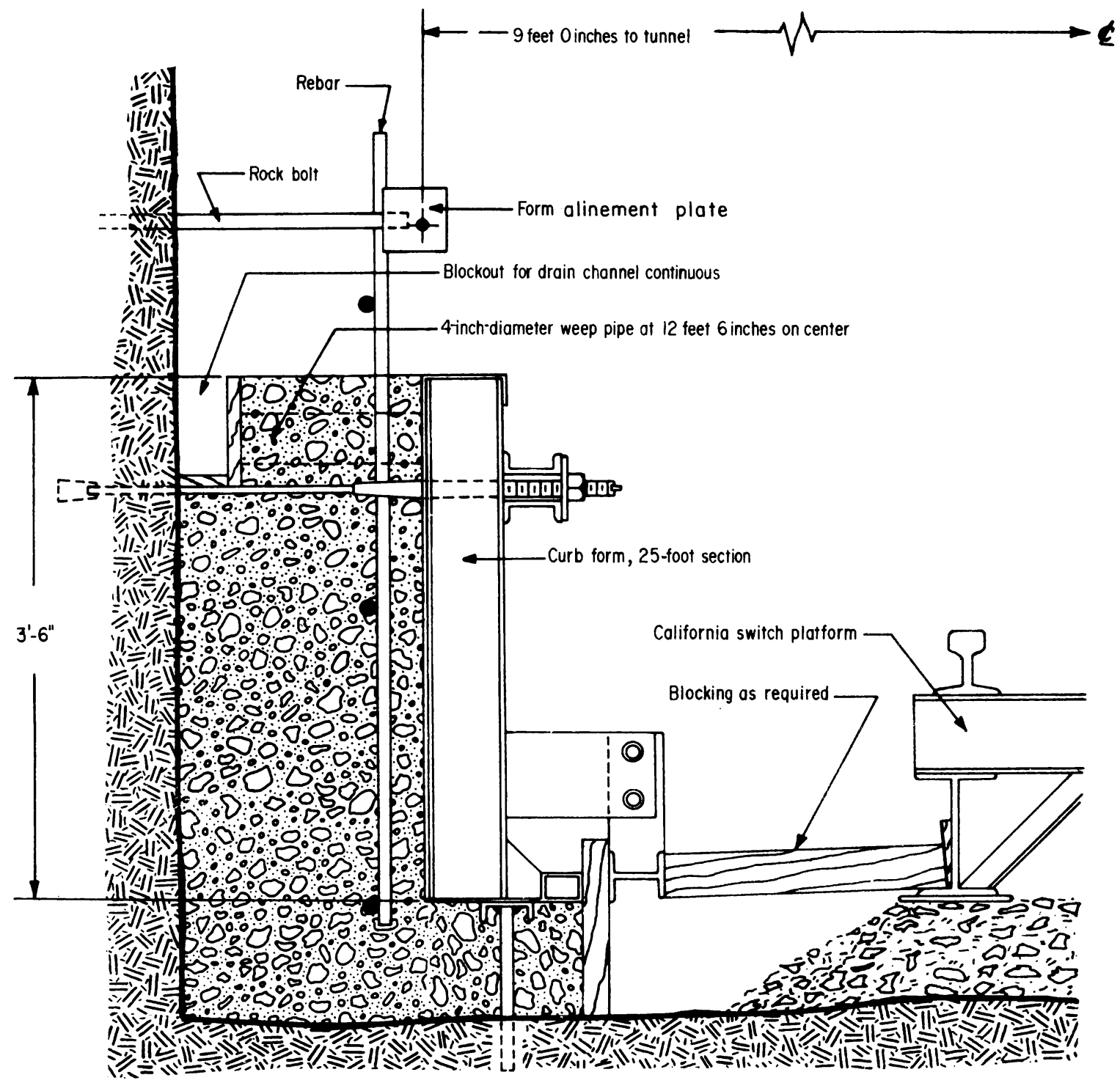

FIGURE 34. - Invert curb formwork.

General1y, 200 lineal feet of curb on one side of the tunnel was placed (a 75-to 90-cubic-yard pour) on day shift with the opposite curb being prepared concurrently for placement the following day. Tunnel excavation proceeded simultaneously with little or no interference. Upon tunnel holing through on June 21,1968 , only 12,600 feet of curbing in the tunnel remained to be placed. This length was completed from the north portal by october 24 , 1968. A11 curb concrete was transported into the tunnel by 6-yard agitator cars manufactured by Moran Engineering Co. Placement into the curb formwork was by means of a placing conveyor from the agitator cars. Four hundred feet of curb forms was purchased for each portal. Refuge chambers and transformer bays were also lined during this period. A Whiteman 4-inch concrete pump was used along with a concrete train of three 6-cubic-yard agitator cars. 


\section{Invert Concrete}

Invert concrete pouring was started from the south portal plant on July 9, 1968, while remaining curb concrete was being completed from the north portal concrete plant. Actual pouring began approximately 13,000 feet inward from the south portal and worked toward the south portal. When the south portal was reached, the placing equipment was turned around and driven through the tunnel, where the remaining 23,000 feet of invert was placed from the north portal plant and completed November 9, 1968.

The invert concrete placing scheme utilized a 630-foot-1ong bridge conveyor feeding a 20-foot-long radial placing conveyor. These units rode along roller supports placed in the previously installed 4-inch-diameter weep holes (on 12-foot, 6-inch centers) embedded in the curb concrete (fig. 34). The rubber-tired invert screed, including the trailing sub-ballast bed-forming shoulder members, was 95 feet 1 ong and was supported on the 12inch-wide lip of concrete projecting from the toe of the previously placed curb concrete (fig. 34).

A gantry-type cleanup conveyor 100 feet long preceded the placing equipment and allowed concrete delivery equipment to pass back and forth. A typical invert concrete cycle consisted' of cleaning out a 450 -foot length of tunnel invert section on swing and graveyard shifts. Rail track was taken up in 33-foot sections and temporarily laid on steel dowels driven into rock above the curb concrete. The day shift then placed invert concrete in the cleaned-out section made ready by the previous two shifts. All operations advanced towards the concrete batching plant. After curing, the rail track was relaid to exact 1 ine and grade for the wall and arch formwork and bolted into the invert concrete at 10 -foot centers.

Concrete for the invert was called a lean mix with only 2.5 sacks per cubic yard and a water-cement ratio of 0.990 , by weight. Table 7 lists typical specifications for a 1 -cubic-yard mix in the invert. This mix proved adequate for its intended purpose and provided sufficient strength $(1,275$ psi) to withstand loads imposed by the arch formwork. Trains of three 6-cubicyard agitator cars transported invert concrete. Between 500 and 600 feet of invert was poured per day.

\section{TABLE 7. - Lean invert concrete mix}

\begin{tabular}{|c|c|}
\hline & Weight \\
\hline Cement ( 2.5 bags $) \ldots$ & 235 \\
\hline Water (28 gallons)....... & 233 \\
\hline Sand.............. & 1,395 \\
\hline $3 / 4$-inch aggregate........ & 831 \\
\hline $1-1 / 2$-inch aggregate...... & 1,242 \\
\hline Calculated unit weight ${ }^{1} \ldots \ldots .1 \mathrm{~b} / \mathrm{ft}^{3} \ldots$ & 152.6 \\
\hline
\end{tabular}

${ }^{1}$ With 4.5 volume-percent air. 
Invert concrete operations were scheduled before wall and arch concrete for several operational reasons. First, the raised invert shoulder was to be an integral part of the arch form support scheme, and accessory restraint hardware was thereby eliminated. Secondly, close tolerances of track grade and alinement were required for successful operation of wall and arch form setting and concrete placing equipment. Concrete placement could, of course, be accelerated with a well-supported straight track. These advantages were considered to outweigh the necessity of having to take up and relay all tunnel track one extra time. Other advantages gained would be better water drainage, increased mobility of California switches, and a safer floor area more conducive to a high-production concrete operation.

\section{Wa11 and Arch Concrete}

Final concreting operations for the wall and arch began December 2, 1968, from the south portal advancing towards the north. Working 5 days per week, 3 shifts per day, and with some downtime, the lining was completed in 127 days on June 27, 1969. A11 concrete was batched and delivered from the winterized concrete plant located at the north portal.

A typical 1-cubic-yard mix design is shown in table 8. Type II cement was used. Water-cement ratio was 0.457 , by weight. Protex air entrainer was also added. Some field adjustments were made in the weights of sand and aggregates batched depending on moisture contents. Normal mix was 30 gallons, but mixes of 232 pounds of water were also used. Compressive strengths of concrete test cylinders at 28 days regularly exceeded 4,000 psi, with some greater than 5,000 psi.

TABLE 8. - Wall and arch concrete mix

\begin{tabular}{|c|c|}
\hline & Weight \\
\hline Cement ( 5.40 bags) .........1b/yd ${ }^{3} \ldots$ & 508 \\
\hline Water $(30 \text { gallons })^{1} \ldots \ldots \ldots . .1 b / y^{3} \ldots$ & 250 \\
\hline Sand $\ldots \ldots \ldots \ldots \ldots \ldots \ldots \ldots . \ldots 1 b / y^{3} \ldots \ldots$ & 1,265 \\
\hline $3 / 4-$ inch aggregate..........1b/yd ${ }^{3} \ldots$ & 825 \\
\hline $1-1 / 2$-inch aggregate........1b/yd ${ }^{3} \ldots$ & 1,240 \\
\hline Calculated unit weight ${ }^{3} \ldots \ldots 1 \mathrm{~b} / \mathrm{ft}^{3} \ldots$ & 153.3 \\
\hline 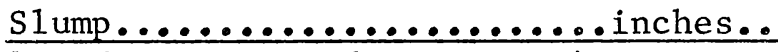 & $2-1 / 2$ \\
\hline $\begin{array}{l}\text { ISand was assumed to carry } 4 \text { percent } \\
\text { and aggregates } 2 \text { percent. }\end{array}$ & \\
\hline
\end{tabular}

Concrete specifications required that below the tunnel springline, openings in the formwork be used, and that in the crown, concrete be placed by nonpneumatic methods. Minimum allowable form-setting time prior to stripping was 16 hours. To meet these and previously discussed design criteria, the continuous-pour method was maximized around a self-propelled conveyor placing system working in conjunction with a concrete pump. An important point in concrete formwork was that the relatively high (4-foot) concrete curb placed prior to the invert provided sufficient clearance to eliminate any hinged skirt. Consequently, extremely rigid formwork was designed. No float or support blocking proved necessary. 
Formwork was supplied by Ewing-Records and Associates, Converse, Tex. Initially, 312 feet of forms was purchased, but another 48 feet was soon found necessary because of the 16-hour minimum setting time. The 360 feet of wal1 and arch forms was sufficient for completion of the project. Lining formwork was in 8-foot panels and constructed in 24-foot sections. The total 360-foot length of forms comprised 15 sections (fig. 35). Each section in use was held against the curb by a series of jacks braced to the sloping sides of the raised invert section as discussed in the section on design and construction problems. A self-propelled jumbo car with hydraulic tongs for handling the forms was capable of moving under the form and with the bracing removed,

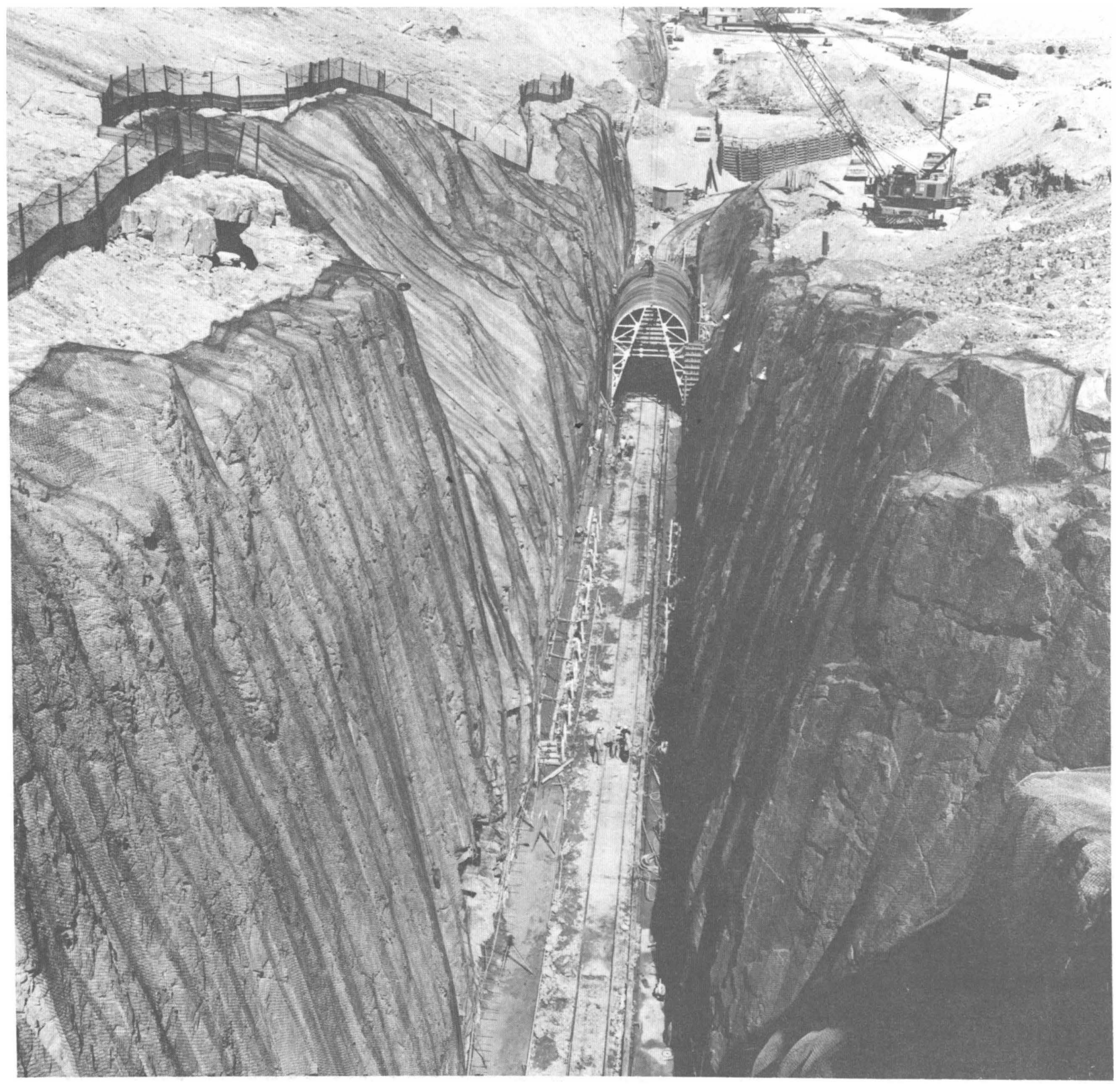

FIGURE 35. - Typical concrete formwork section at north portal. 
allowing the collapsed section to be moved through the remaining forms, Although, as mentioned previously, the skirt was not hinged, the form was hinged at the arch for ease in collapsing the form inward and downward. The hydraulic form-setting system considerably eased successive section alinement, which normally required about 30 minutes.

Origina11y designed forms had 18- by 24-inch doors located at 7-1/2-, 11-1/2-, and 15-1/2-foot intervals above the curb construction joint, and another door 1-3/4 feet below the tunnel centerline in the arch. All doors were spaced at 8-foot centers longitudinally. An additional door was added midway between the original springline door and arch door in each panel during field operations. This extra door was useful for additional vibration and inspection during concreting. Modifications were also made to the concreteplacing conveyor system so that concrete could be placed through these doors using short transverse conveyors mounted at the discharge end of the 1ongitudinal inclined conveyors.

The first part of the wall and arch concrete-placing conveyor system consisted of a 55-foot inclined conveyor carrying mix directly from the Moran agitator cars to a storage hopper mounted on the deck of the conveyor jumbo. From the storage hopper, twin gates discharged onto two side-by-side shortinclined conveyors that discharged (by means of stationary plow stations) into chutes through the previously described series of doors in the formwork. Vibrators were then worked through the windows.

Often, the conveyor placing system had to be moved back towards the concrete pump gantry to allow 24 -foot sections of formwork to be moved ahead and reset. The concrete placing system was, therefore, inoperable for approximately 20 minutes for each reinstallation of formwork. As noted, the selfpropelled system was advantageous for this. About 45 percent of the total wall and arch concrete was placed by conveyors, and the placing rate was sufficient to maintain schedules even though the placing system was inoperable during the aforementioned interval.

The arch concrete was placed by a Rex model 200 double-action pumpcrete mounted on a high car gantry jumbo which allowed concrete trains to pass through to the placing conveyor about 300 feet ahead. The slickline consisted of more than 33 feet of 9-inch-OD, 3/8-inch-wa11 steel tubing flattened to an elliptical section. Most of this line was usable for the duration of arch concrete operations without changing, resisting wear from approximately 120,000 cubic yards of pumped concrete. Short end sections were cut off periodically as wear became excessive. The slickline was buried a minimum of 10 feet in arch concrete. A 2 -inch air line was carried with the slickline about 30 feet behind the buried end to allow air slugging to fully fill the tunnel arch. Maintenance on the concrete pump was performed on weekends, and the entire lining operation was completed without major pump breakdown. The slickline projection previously referred to (fig. 30) was not removed.

Initially, six concrete trains consisting of three 6-cubic-yard Moran agitator cars and a 25-ton diesel locomotive were used for concrete delivery. All concrete was transported from the north portal batching plant. Three 
California switches and three passing tracks constructed on the concrete tunne1 invert provided necessary train passing areas. One switch, closest to the formwork, allowed one train to discharge at the concrete pump while another, train traveled to or from the placing conveyor. This switch was moved several times daily to keep pace with the rate of concrete placement. A second switch was located approximately 500 to 2,000 feet ahead of the placing equipment, and was moved each week. The remaining switch and passing tracks were spaced at approximately 1-1/2-mile intervals. As successive passing tracks were reached by advancing operations, one of the six concrete trains was eliminated in turn.

Accessory equipment used were several high cars and jumbos. One car was used for attending the end of the concrete slickline, and one car was used ahead and behind the form jumbo for vibrating forms. Thus, when the form jumbo was either setting or stripping forms, a high car was always available at the advancing concrete. A11 the arch concrete placing and forming equipment was self-propelled. Also, all the concrete equipment, except the pump gantry, traveled on the regular 42 -inch construction track laid in the tunnel.

Several more high cars and jumbos were used in the placing of embedded items, such as continuous curtains of No. 5 and No. 6 reinforcement stee1, installation of more than 42 miles of plastic electrical conduit (see Fig. 30), drain pipe, and junction boxes. These items were emplaced at least $1 / 2 \mathrm{mile}$ ahead of the concrete operation. Less than anticipated drainage pipe was installed due to water inflow being less than expected during excavation. Prior to this work and following curb placement, the 46-inch fan line had been removed and a bulkhead installed over the south portal. Three Joy axivane fans were mounted in the arch of the bulkhead and supplied approximately 135,000 cubic feet per minute throughout concrete operations.

A finishing jumbo followed wall and arch concreting as the forms were removed. All concrete surface irregularities were repaired and the concrete was sprayed with a Protex curing compound. Later, selected test holes were drilled to determine effective thickness of concrete placement. Wheré deficiencies were evident, a portable grouting jumbo completed the additional work. Approximately 200 cubic yards of concrete grout were backfilled behind the liner (pay item). Most of the grout was placed in the fault zones, especially the E1k Mountain Fault zone.

The average rate of wall and arch concrete placement was approximately 1,361 feet per week, with a maximum of 2,644 cubic yards poured per day. A complete schedule of wall and arch concrete lining progress is shown in table 9. Week1y lining progress was quite variable and, as the footnote comments show in table 9 , was affected by aggregate haulage. 
TABLE 9. - Weekly wall and arch concrete 1ining progress

\begin{tabular}{|c|c|c|c|c|}
\hline 70 & Begin & End & $\begin{array}{l}\text { Weekly } \\
\text { progress, feet }\end{array}$ & $\begin{array}{c}\text { Cumulative } \\
\text { progress, feet }\end{array}$ \\
\hline Dec. 2, 1968-Jan. 1, 19691_.. & $3356+00$ & $3338+67$ & 1,733 & 1,733 \\
\hline Jan. $6-13,1969 \ldots \ldots \ldots \ldots \ldots$ & $3338+67$ & $3329+26$ & 941 & 2,674 \\
\hline Jan. $13-20,1969 \ldots \ldots \ldots \ldots \ldots$ & $3329+26$ & $3319+20$ & 1,006 & 3,680 \\
\hline Jan. $20-27,1969 \ldots \ldots \ldots \ldots \ldots$ & $3319+20$ & $3308+17$ & 1,103 & 4,783 \\
\hline Jan. 27-Feb. 3, 1969_....... & $3308+17$ & $3296+89$ & 1,128 & 5,911 \\
\hline Feb. $3-10,1969 \ldots \ldots \ldots \ldots \ldots$ & $3296+89$ & $3284+42$ & 1,247 & 7,158 \\
\hline Feb. $10-17,1969 \ldots \ldots \ldots \ldots \ldots$ & $3284+42$ & $3272+67$ & 1,175 & 8,333 \\
\hline Feb. $17-24,1969 \ldots \ldots \ldots \ldots \ldots$ & $3272+67$ & $3259+71$ & 1,296 & 9,629 \\
\hline Feb. 24-Mar. 3, 1969_....... & $3259+71$ & $3245+32$ & 1,439 & 11,068 \\
\hline Mar. $3-10,1969^{2} \ldots \ldots \ldots \ldots \ldots$ & $3245+32$ & $3233+08$ & 1,224 & 12,292 \\
\hline Mar. $10-17,1969^{3}, \ldots \ldots \ldots \ldots$ & $3233+08$ & $3220+86$ & 1,222 & 13,514 \\
\hline Mar. $17-24,1969^{4} \ldots \ldots \ldots \ldots$ & $3220+86$ & $3203+58$ & 1,728 & 15,242 \\
\hline Mar. 24-31, 19695.......... & $3203+58$ & $3189+66$ & 1,392 & 16,634 \\
\hline Mar. 31-Apr. 7, 1969_...... & $3189+66$ & $3176+46$ & 1,320 & 17,954 \\
\hline Apr. $7-14,1969^{6} \ldots$ & $3176+46$ & $3162+78$ & 1,368 & 19,322 \\
\hline Apr. $14-21,1969^{6} \ldots$ & $3162+78$ & $3149+86$ & 1,292 & 20,614 \\
\hline Apr. $21-28,1969^{7} \ldots \ldots \ldots \ldots$ & $3149+86$ & $3134+27$ & 1,559 & 22,173 \\
\hline Apr. 28-May 5, 1969........ & $3134+27$ & $3117+72$ & 1,655 & 23,828 \\
\hline May $5-12,1969, \ldots$ & $3117+72$ & $3101+39$ & 1,633 & 25,461 \\
\hline May $12-19,1969 \ldots$ & $3101+39$ & $3087+33$ & 1,416 & 26,877 \\
\hline May $19-26,1969 \ldots \ldots \ldots \ldots \ldots$ & $3087+33$ & $3070+19$ & 1,704 & 28,581 \\
\hline May 26-June 2, 1969......... & $3070+19$ & $3058+92$ & 1,127 & 29,708 \\
\hline June $2-9,1969 \ldots$ & $3058+92$ & $3043+08$ & 1,584 & 31,292 \\
\hline June $9-16,1969 \ldots$ & $3043+08$ & $3031+74$ & 1,134 & 32,426 \\
\hline June $16-23,1969 \ldots \ldots \ldots \ldots \ldots$ & $3031+74$ & $3015+72$ & 1,602 & 34,028 \\
\hline June $23-27,1969 \ldots \ldots \ldots \ldots$ & $3015+72$ & $83002+00$ & 1,372 & 35,400 \\
\hline
\end{tabular}

${ }^{1}$ No lining Christmas and New Year's week.

${ }^{2}$ No lining work Friday to replenish sand/gravel stockpile.

${ }^{3}$ Highway load 1imits cut one-third.

${ }^{4}$ Hauling shut down March 21.

${ }^{5}$ No 1 ining March 28.

${ }_{7}^{6}$ Due to highway 1 oad restrictions work 1 imited to 4 days.

${ }^{7}$ Due to highway load restrictions work limited to 4-1/2 days.

${ }^{8}$ Includes 100 feet across Burrow's Creek.

The entire concreting operation was handled with a total work crew of about 45 men per shift. Normal working weeks were 5 -day, with three shifts per day. As mentioned, continuous concrete placement and elimination of waterstop joints were the basis of the value engineering proposal; however, waterstop joints were placed at the end of each week's pour. A methods analysis of concrete lining for the Flathead Tunnel should be compared with those given in previous papers ( $6, \underline{41}-\underline{42})$. 


\section{Temporary Support Instrumentation}

\section{Rock Behavior Measurements}

The Flathead Tunnel instrumentation program gathered basic data on rock deformation about a tunnel opening near the heading face. Previous geologic information discussed in this report, and known prior to tunneling, had shown that experience in tunneling under similar conditions would indicate support problems requiring further definition. Therefore, the purpose of these measurements was to establish reasonable and realistic guides for determining support requirements. The instrumentation program was included in the contract as an integral part of the invitation to bid ( $\underline{43})$. Initially, the program was to include 30 borehole extensometers; some of these were expended early to acquaint personnel with the program, to test measurement procedures, and to use equipment under field conditions.

An instrumentation station was to consist of three eight-position borehole extensometers, one on each horizontal rib at the springline and one vertically into the crown. A station was placed between the first two sets immediately behind the heading face. 8 These installations were completed on Sunday, the one day with no tunnel excavation. Data collection began on the following Monday with an elapsed time established as about 50 hours from firing of the last round. Plots subsequently shown in this report are based on a zero time of 50 hours following the last heading blast.

The multiple-position borehole extensometer (MPBX), mode1 F-2, was supplied by Terrametrics Inc., Denver, Colo. The instrument required a 3inch drill hole alined either slightly off vertical or slightly above horizontal (to facilitate water drainage), but approximately perpendicular to the rock surface. Eight anchor reference positions were spaced along the borehole axis with the sensor head fixed at the collalr of the borehole. The attached wire between each reference point and the sensor head was 0.041 inch-diameter, spring-tempered 302 steel. MPBX extensometers are designed for measuring strain gradients and total strain along a borehole. The MPBX system was composed of five principal components--instrument head, collar anchor, downhole anchors, signal cable, and readout apparatus. The portable readout apparatus operated on the digital null-balance principal with zerocenter visual meter. Full bridge circuits were used. Each instrument was furnished with multiconductor signal cable with quick-connect plugs.

Deficiencies with the earlier installations had shown that improvements were needed more in design of the electrical equipment than in mechanical features of the system. Improvements were therefore made by the use of bonded strain gages, use of redundant readout units, calibration refinement, and a reference standard for use in conjunction with underground readings. With incorporation of these features into the remaining instrumentation effort, the quality of data became acceptable to the Corps of Engineers.

\footnotetext{
${ }^{8}$ This was partly based on safety considerations, as personnel were not allowed
} forward of the last support at the face. 
After installation of an MPBX station, initial readings were taken twice each shift, three shifts per day for about the next 2 weeks (nearly 300 hours), then once per day for the next 300 hours, and finally once per week up to the time concrete lining obliterated that station. Two different readout instruments were used at each heading as well as a dummy standard for reference readings. By taking readings on one readout, then on the standard, followed by repeating the process with the second readout, accuracy and reliability were achieved.

Although recorded data directly pertain to localized borehole rock behavior, it is most convenient to describe rock behavior with respect to the larger tunnel opening. ${ }^{9}$ Data interpretation for this report was made on that basis. Analysis was based on axial borehole extension (interpreted tension) and borehole contraction (interpreted compression). The following presentation used extension of the smaller borehole as indicating closure of the tunnel opening; conversely, borehole contraction represented dilation of the tunnel opening. Al1 data subsequently graphed upward on the displacement axes are tunnel closure with all plots of individual anchor movements with respect to the most distant anchor (indicated as anchor 8).

of the 18 reliable MPBX installations from the tunnel instrumentation program, 4 of these are of special interest and will be discussed in detail. The four records judged of excellent quality in terms of initial deformation are shown in figures 36-39. Records 2512, 2514, and 2563 are a11 from one station, which yielded complete records from both springlines and the crown. Record 2583 was from another station but only from the west springline. Instrument locations and other installation data are shown in table 10.

TABLE 10. - Installation data, selected MPBX stations

\begin{tabular}{l|l|l|l}
\hline Record & Rib position & Station & Date installed \\
\hline $2512 \ldots .$. & West springline.. & $3099+23$ & Sept. 23, 1967. \\
$2514 \ldots .$. & Crown........... & $3099+30$ & Sept. 23, 1967. \\
$2563 \ldots .$. & East springline.. & $3099+20$ & Sept. 23, 1967. \\
$2583 \ldots .$. & West springline.. & $3153+97$ & May 25, 1968. \\
\hline
\end{tabular}

The three records in about the same position (2512, 2514, and 2563) are in ground classified as massive to blocky with an overburden of 215 feet. Support in this ground consisted of a 235-foot section of 8-inch sets on 3foot centers. These three records are considered to represent rock deformation typical of most of the tunnel length. Record 2583 was in a fault zone, solidly lagged and carried by a 66-foot length of 8 -inch sets on 4-foot centers. The ground would be classified as highly fractured and broken. Overburden was 260 feet. This record is considered as representing rock deformation typical of faulted rock.

\footnotetext{
${ }^{9}$ Data interpretation is solely based on the author's and Bureau of Mines experience and does not reflect the views or opinions of the Corps of Engineers.
} 


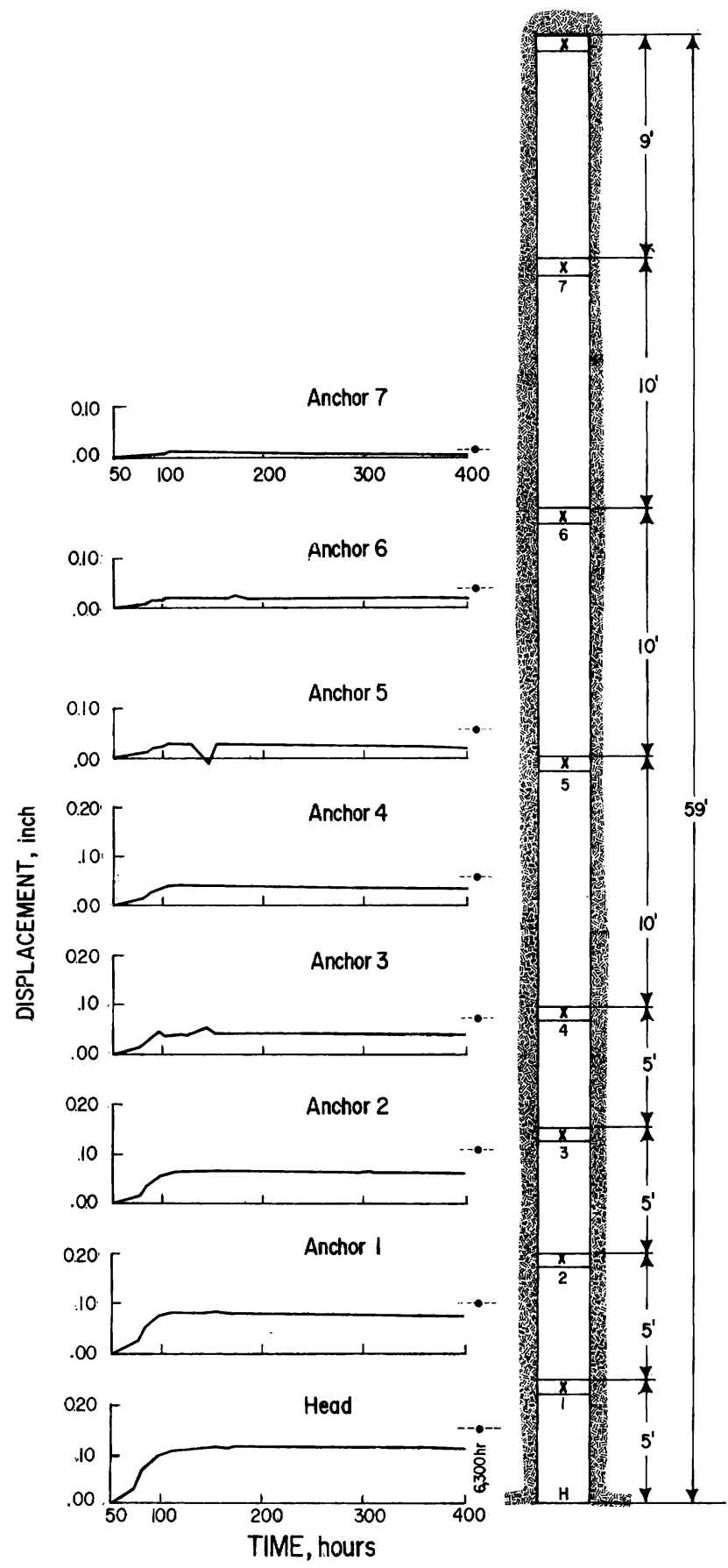

FIGURE 36. - Deformation record 2512.

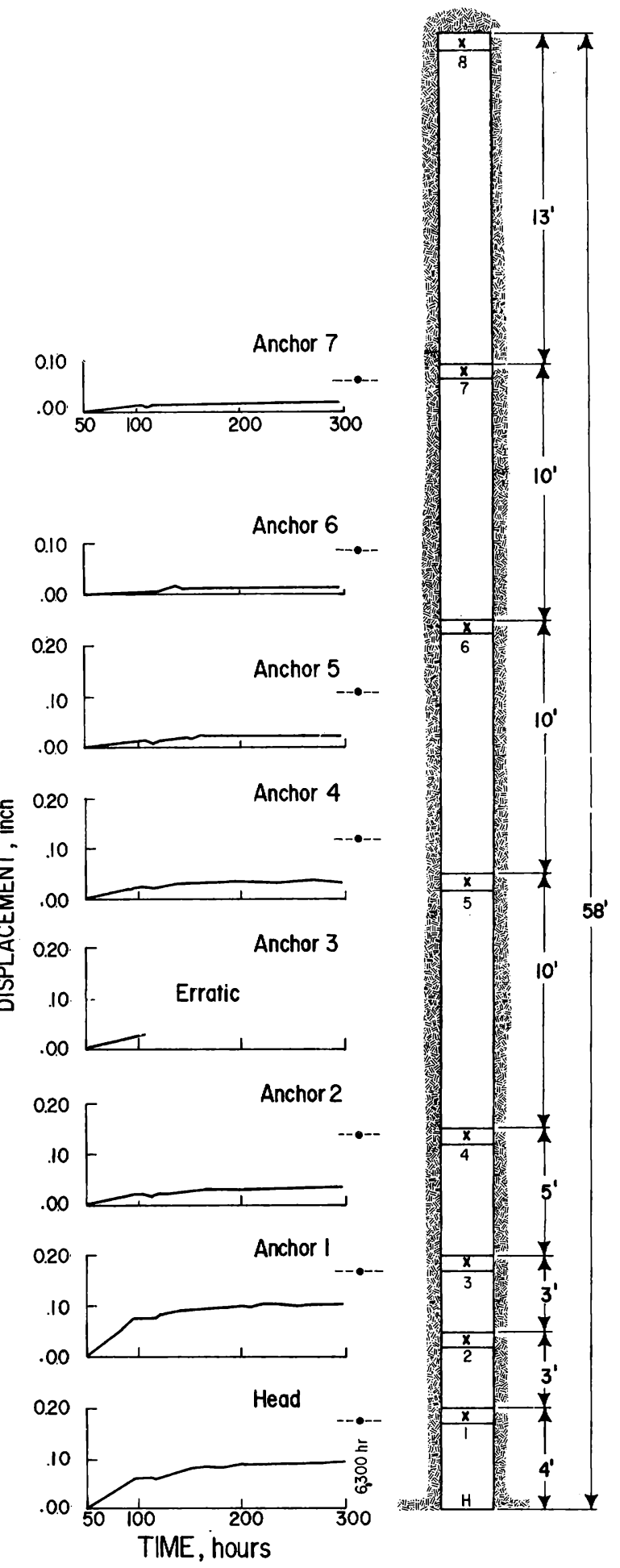

FIGURE 37. - Deformation record 2514. 


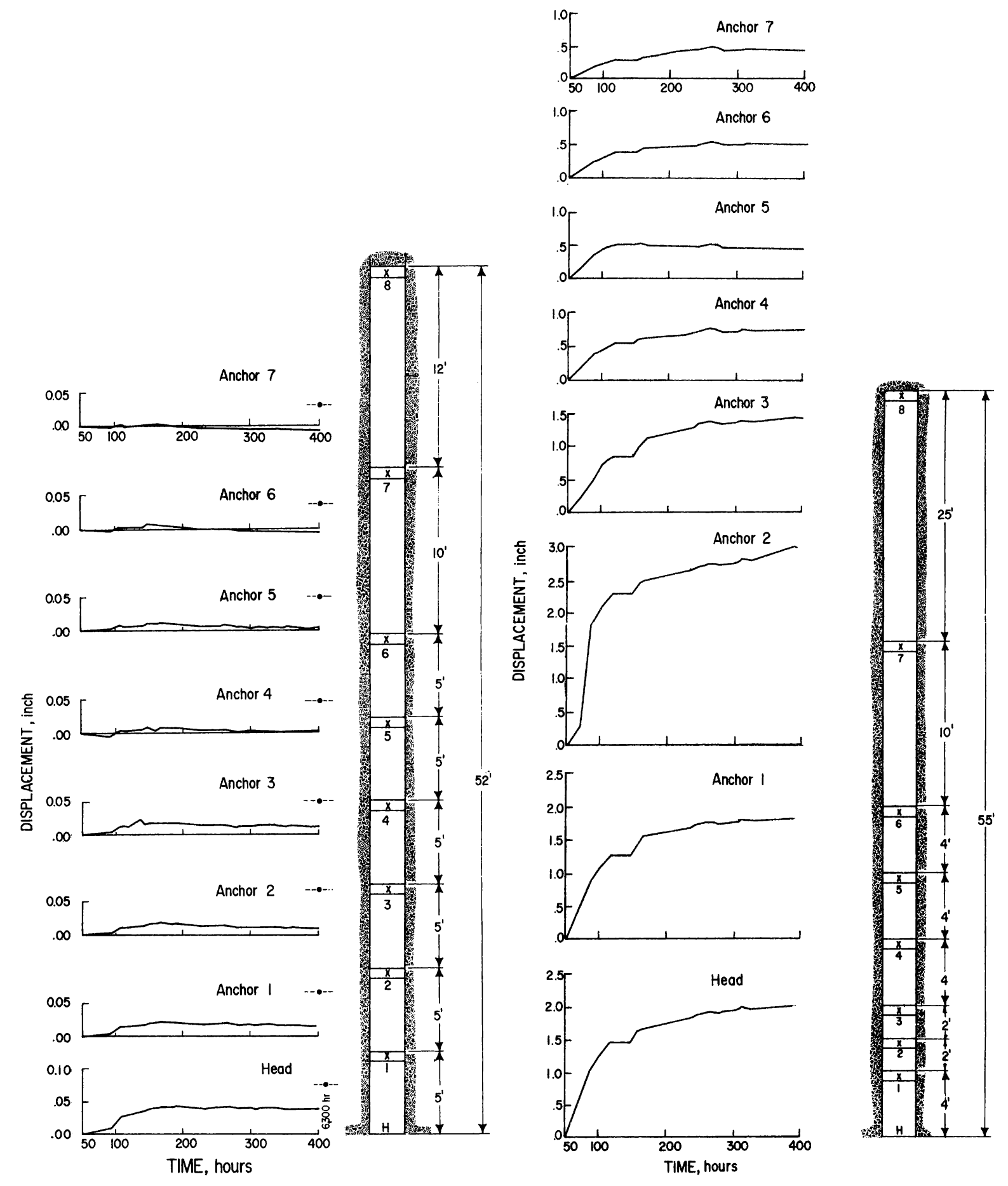

FIGURE 38. - Deformation record 2563.

FIGURE 39. - Deformation record 2583. 
The character of the initial displacement portion of these four records is an apparent irregular, but steady, increase of displacement leading to the long-term plateau. This was apparent even in those records showing very sma11 closure or dilation displacement. Throughout all four records, an apparent peak displacement is noted at between 100 and 200 hours; only record 2583 has a longer rise time to peak initial displacement. The initial deformation rise is also steeper. This difference is attributed to rock conditions at gage placement. Beyond the plateau of initial deformation, the records show a lengthy period of steady increase in displacement up to the time of "hole-through". Hole-through events will be discussed later.

On records 2512, 2514, and 2563, just above the 300-hour Iine, a dot and dashed line marked 6300 hours is shown (figs. 36-38). This is the approximate straight-1ine projection of the record from 300 out to 6,300 hours. This will be discussed later in long-term closure displacements. Record 2583 has no such mark, as the record later became erratic at 500 hours.

Another interpretation of these four records is shown in figure 40. Using the peak initial displacement at the tunnel rib as a maximum, each anchor displacement at depth in the rock is simply divided by this value. This procedure is a commonly used method in rock mechanics and elasticity to obtain dimensionless plots without regards to the magnitude (28). The results in figure 40 illustrate the rapid decrease in displacement near an $\mathrm{r} / \mathrm{a}$ of about 2 , which is one tunnel radius outward into the rock ( $r$ is the depth of consideration and $a$ is the tunnel radius). Displacement uniformly decreases thereafter. On record 2583, anchor 2, a rock displacement is noted at depth slightly greater than for rock at the tunnel rib. Record 2514, anchor 1, also shows this, but to a lesser extent. The interpretation is that irrecoverable outward blasting induced dilation, which is especially pronounced in faulted rock.

This plot of normalized deformation data is interpreted as validating the support design assumption that the minimum support installed ( $6 \mathrm{H} 20$ at 4-foot centers, which were designed to support 11 feet of rock, or 1 radius) was indeed required to normally support about 11 feet of rock. Coincidental data, described in the section on tunnel support fallure, established the fact that the maximum depth of rock fallout was also approximately one tunnel radius.

Long-term closure displacement rates calculated between 300 and 6,300 hours for records 2512 (west springline) and 2563 (east springline) show about 5.0 and 7.0 microinches per hour, respectively, for the head anchor and for each anchor through anchor 6, or a distance of about 40 feet. Record 2512, in the crown, shows a closure rate of about 14 microinches per hour, or twice the rib closure rate. No 1 ong-term data was available for record 2583; a11 data became erratic at near 500 hours. The interval 300 to 6,300 hours was selected as that portion of stable record between the initial plateau and just before the "hole-through" anomaly.

The interesting conclusion from these calculated long-term closure rates is that each individual measurement point between the head and anchor 6 


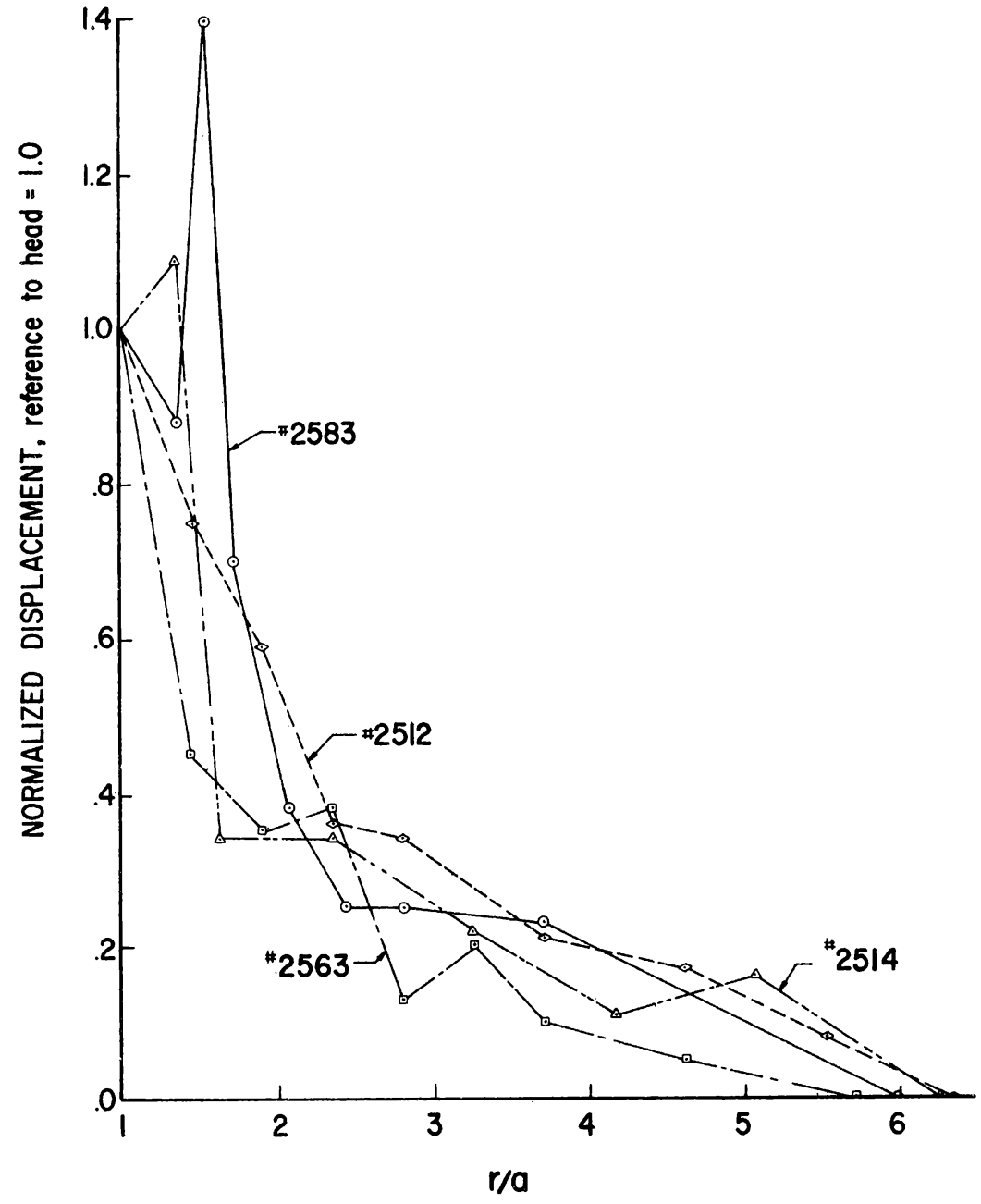

FIGURE 40. - Normalized displacement with respect to tunnel rib. indicated nearly identical

closure, or within

measurement error. The

interpretation is that

uniform time rate of

closure occurs for all

rock between the tunnel

rib and anchor 6 , or out to

approximately two diameters;

that is, the rock moves

uniformly inward. A very

sharp decrease is noted

for anchor 7 (recalling

that all displacements

are with respect to

anchor 8) on records 2512

and 2538, except for

record 2514 (crown) where

the closure rate for

anchor 7 was 7.5 micro-

inches per hour. This is

nearly the closure rate

for the ribs. Long-term

portions of these four

records contain two worth-

while features. The first

feature is a slow rise and

fall in displacement with

a period of 1,000 hours or more. This record event may be due to slight reading errors or to seasonal temperature change of tunne1 atmosphere.

Another long-term record anomaly was noted upon firing the "hole-through," or last round when all records (from every installation and every anchor, regardless of the quality of prior data) showed a "hole-through" excursion in the plot. For most successful stations this occurred after nearly 6,500 hours of continuous recording. About half of the records showed closure for the first direction of movement on all anchors; some showed entirely dilation, and some showed closure on certain anchors and dilation on other anchors. A few did not show the phenomena. The later time data continued to show either closure or dilation excursion; some records had excursions exceeding any previous deformation. Most of these records could be somewhat described as undamped harmonic curves. This harmonic motion continued for some hundred or so hours after the initial event before being reduced to displacement values very near that occurring before the event. No explanation supported by experimental evidence is available for these "hole-through" excursions. This rock behavior pattern apparent1y had no significance with respect to ground support. 
Similar excursions occurred upon cessation of blasting at the north heading prior to hole through.

In addition to these four records described in detail, eight other records were also of interest. Three significant records showed 1ittle or no measurable displacements from all anchor points. Considering the reliability of measurement technique, it is inferred that the rock displayed correspondingly little or no displacement as a result of creating the tunnel opening. Another group of five records displayed slight to measurable displacement. However, data plots from each anchor of these records gave deformation trends recording opening dilation, indicating irrecoverable outward deformation. These eight records showing little or no movement represented nearly half of all reliable records.

The remaining records are all from four stations within a portion of tunnel approximately between the Rebel Fault and the fractured zone preceding the Elk Mountain Fault (to the south). Rock conditions for these stations are collectively described as highly fractured to blocky bedded rock having shallow to near horizontal dip. Localized steep1y dipping shear and bedding plane faults were also present. Overburden ranged from 400 to 1,250 feet. No effect of the excavation rate or the influence of faulting on the records could be clearly identified, although major project faulting was intersected and excavation was continuous through all stations. The one outstanding observation from this group of records would be that little or no closure deformation occurred from extensometers within ground classed as blocky and as measured somewhat parallel to obliquely along the bedding strike.

A1though data from the instrumentation program furnished valuable results, their usefulness in support determination at the heading face was not successful. One difficulty was the time required for the displacement record to fully develop. At a rate of tunnel progress exceeding 60 feet per day, the heading would easily be nearly 750 feet ahead of the instrument station before the record could display its character at about 300 hours. Secondly, no precedent in support design theory was available to evaluate the results in terms of either temporary or permanent support. Those records showing erratic movements unfortunately must be classified as without precedent for interpretation; hence, they were regretfully discarded without evaluation.

\section{Support Load Measurements}

Prop load cells were installed under the legs of steel sets. Of necessity this had to be done for the set nearest the face to obtain meaningful loads on steel supports. Unfortunately, with set footblocks always in water and production tunneling rounds fired a few feet away, reliable results could not be obtained. Therefore, the data obtained at all prop load installations were erratic, resulting in no meaningful interpretation and were considered valueless. 


\section{Rock-Bo1t Tests}

Tests were conducted on the performance of 10 -foot rock bolts used for regular tunnel support at the south heading approximately 1 month after the heading was begun. A section of selected tunnel was used with 10 rock bolts spaced 3 to 4 feet above the springline on the west rib between previously placed steel sets. When installed, the test section was 240 feet behind the advancing face. The local geology was well-fractured rock striking $\mathrm{N} 30^{\circ}-40^{\circ} \mathrm{E}$, and dipping near vertical. Joint spacing was $1 / 4$ to $1 / 2$ foot with joint filling of clay.

Two days after initial installation, torque was checked and a11 rock bolts were then retorqued to 250 pounds. It was found that 7 of the 10 bolts lost initial torque, with lossed ranging from 20 to 150 foot-pounds. The average loss was 90 foot-pounds. Two days later, a11 rock bolts were again checked and it was found that only three rock bolts lost torque, with losses of 25, 80, and 110 foot-pounds. These three were among the seven that previously lost torque. Two of these three could not be retorqued to 250 footpounds. It was considered that the loss of rock-bolt load was solely caused by poor anchorage in the well-fractured rock. A11 torque tests were done with Williams Form Engineering Corp. equipment.

Two of the best torqued rock bolts anchored in apparently firm rock were pulled to failure. Anchorage creep appeared on one rock bolt at approximately 15,000 pounds tension and 21,000 pounds tension on the other. Rapid slippage of the anchor occurred soon after initial creep. The torque yield load, bolt elongation, and yield point were not determined.

Another five rock-bolt pullout tests were done on about March 1, 1967. These tests were used to confirm a decision on the method of tiedown for sectional concrete formwork. However, as discussed previously in the value engineering section, this concept was discarded in favor of continuous formwork. The following rock-bolt pullout tests were directly influential to that decision. Rock bolts used were 7/8-inch-diameter, 5-foot-1ong, hightensile bolts with 1ong stop-type anchor cone manufactured by Williams Form Engineering Corp. The rated working load of these rock bolts is 45,000 pounds. Installation hole size drilled was 1-3/4 inch diameter. The bolts were torqued with air-driven impact wrench, and pullout tests were conducted with Terrametrics equipment.

Of the five tests, three in the south heading and two in the north heading, four rock bolts held stable at 21, 27, 29, and 29 tons, and one rockbolt anchor failed completely in badly fractured soft rock. It was concluded that the high reliability necessary for concrete formwork could not be achieved with a rock-bolt anchorage system. This failure, combined with the necessity for positive means of anchorage in those lengths of known poor rock, along with close concrete tolerances and high concrete placement schedules, made an alternative necessary. This point was extensively discussed in the section on design and construction problems. 


\section{Physical Properties}

No physical property tests were made on rock material encountered at the tunnel site. Only rock description, core recovery, and general drilling data were recorded and some pumping and pressure tests conducted during the exploratory drilling program. Abundant soil tests for purposes of earthwork design were made for the railroad embankment. Heavy emphasis was placed on properties of concrete aggregate. All these tests, however, are considered outside the scope of this report.

At suspected bad ground locations, a series of NX exploratory core holes totaling 2,073 linear feet were drilled underground at 17 locations by mutual agreement between the Corps of Engineers and the contractor. Hole lengths ranged from 40 to 181 feet. A11 but two holes, totaling 244 feet, in the south portal, were drilled near the tunnel face at about $35^{\circ}$ outward from the tunnel centerline. The recovered core was used only for visual inspection of rock conditions ahead of the face. The greatest emphasis was placed on determining the presence of rock discontinuities obtained from detailed surface geologic mapping rather than numerical values of rock strength (13).

For reference purposes, four selected quartzitic argillite samples from the damsite are presented in table 11. These were selected from rock cores deemed representative of rock types closely resembling those, found at the tunnel site (see section on Belt rocks). In these data it should be noted that three groups of core were used--one group for dynamic tests, one for shear tests, and one for compression tests. The compression test graphs show linear trends, and the modulus value is the tangent modulus. Poisson's ratio is not dynamically derived. Samples were tested by the Corps of Engineers.

TABLE 11. - NX core samples, quartzitic argillites

\begin{tabular}{|c|c|c|c|c|c|c|c|c|c|}
\hline \multirow{3}{*}{ Core } & \multirow{3}{*}{$\begin{array}{l}\text { Spe- } \\
\text { cific } \\
\text { grav- } \\
\text { ity }\end{array}$} & \multirow{3}{*}{$\begin{array}{l}\text { Absorp- } \\
\text { tion, } \\
\text { per- } \\
\text { cent }\end{array}$} & \multirow{3}{*}{$\begin{array}{l}\text { Poros - } \\
\text { ity, } 1 \\
\text { per - } \\
\text { cent }\end{array}$} & \multirow{3}{*}{$\begin{array}{l}\text { Longitu- } \\
\text { dinal } \\
\text { velocity, } \\
\text { fps }\end{array}$} & \multirow{2}{*}{\multicolumn{2}{|c|}{$\begin{array}{l}\text { Elastic } \\
\text { modulus } \\
\text { psi } \times 10^{6}\end{array}$}} & \multicolumn{3}{|c|}{ Static values } \\
\hline & & & & & & & \multirow{2}{*}{$\begin{array}{l}\text { Compres- } \\
\text { sion, } \\
\text { psi }\end{array}$} & \multirow[t]{2}{*}{$\begin{array}{c}\text { Shear, } \\
\text { psi }\end{array}$} & \multirow[t]{2}{*}{$\begin{array}{c}\text { Poisson's } \\
\text { ratio }\end{array}$} \\
\hline & & & & & Dynamic & Static & & & \\
\hline $\mathrm{HH}-3$ & 2.74 & 0.1 & 0.19 & 16,800 & 10.42 & 9.85 & 15,440 & 1,765 & 0.24 \\
\hline DH -9 & 2.73 & .1 & .43 & 17 & 10.84 & 6.47 & 9,820 & 1,275 & .18 \\
\hline $\mathrm{JH}-10$ & 2.70 & .2 & .24 & 16 & 9.63 & 9.63 & 36,140 & 2,925 & .19 \\
\hline $\mathrm{DH}-11$ & 2.78 & .1 & .26 & 17,780 & 11.86 & 10.92 & 26,830 & 2,650 & .28 \\
\hline
\end{tabular}

${ }^{1}$ ASTM C -20 Test method.

\section{Temperature Measurements}

Some limited underground temperature measurements were taken in the spring and summer of 1967. Readings were taken adjacent to the tunnel walls at 300-foot intervals. Throughout May and June 1967, temperatures about 500 to 800 feet behind the heading face ranged from $44^{\circ}$ to $48^{\circ} \mathrm{F}$. Outside air temperatures ranged from $30^{\circ}$ to $40^{\circ} \mathrm{F}$. With outside temperatures ranging from $72^{\circ}$ to $98^{\circ} \mathrm{F}$, heading temperatures ranged from $48^{\circ}$ to $58^{\circ} \mathrm{F}$, but $48^{\circ} \mathrm{F}$ was most prevalent. One typical day's recordings (July 20, 1967) around the clock gave a range of $50^{\circ}$ to $58^{\circ} \mathrm{F}$ with all temperature rise occurring during the 
day shift. Temperatures were consistently higher at the south portal with up to $10^{\circ} \mathrm{F}$ difference being noted. From this limited data, it appears that the time of day has more effect upon underground temperature than does the range of outside air temperature. Measurements of water temperature taken at several inflow seepage points averaged $46^{\circ} \mathrm{F}$.

\section{Stress Field}

Geologic mapping in the tunnel site vicinity (fig. 4) has shown that the predominant folding axes are undulating but oriented about north and south, while nearby igneous dike intrusions, along with numerous faults of some magnitude, strike about east and west. The sedimentary sequence is also known with some certainty.

A state of stress, therefore, might be intuitively deduced from these data following the method of analysis by Hubbert (20). Hal1 (17, p. 53) made a similar review, with more detailed data than presented in this report, of regional evidence for the age of folding and faulting. First, it appears that major sedimentation in a relative'y shallow sea environment was nearly completed by the end of Precambrian time, through remnants of conformable early Paleozoic sediments are found in nearby areas.

Following sedimentation, but prior to Late Cambrian time, and continuing into Paleozoic time, large-scale erosion and tectonic activity accounted for the hiatus in the sedimentary record. Some igneous intrusions also occurred during this time; however, nearby volcanic flows are established as Precambrian.

From radioactive age dating methods it is postulated that most large igneous intrusives in the area were emplaced during Cretaceous time. Larger igneous intrusions outside the area of this report are well dated as Cretaceous. Throughout these periods of tectonic activity, the axes of the presently observed anticlinal-syncline structural system suggest that the principal compressive stress was near horizontal and in the east-west direction. Upon dissipation of this stress field, perhaps by more recent thrust faulting and overturning of folds, the east-west normal faulting developed and igneous dikes were emplaced. One of Hubbert's points is that such igneous intrusions are related to the tectonic stress field. Renewed stresses originating in the east-west direction are known to have reoccurred during Laramide time, as shown by the presence of several very large thrust faults to the east and south.

The rock mass enclosing the tunnel probably continues to reflect the presence of these stress fields. It is concluded that a moderate level of biaxial stress field now exists having a horizontal component somewhat less than the normal vertical stress due to over burden alone. Another intermediate stress component is probably alined in the north-south direction.

No in situ stress measurements were made at the tunnel site. The Corps of Engineers completed contract in situ stress measurements in an exploratory adit driven into the abutment of Libby Dam; these measurements may not be 
directly applicable because of the geometry effect occurring in the narrow steep-walled canyon. The only other in situ measurements made within the region have been in the Coeur d'Alene mining district by the Bureau of Mines and at the Sullivan mine, Kimberly, British Columbia, by Cominco Ltd. Because of the unparalleled circumstances of these measurements, direct comparison and detailed discussion are not warranted. However, stress measurements at the damsite show that stresses are low in magnitude, about equal to the vertical overburden, and their orientation generally conforms with local geologic structural trends.

Although the previous discussion has presented intuitive stress conditions based on regional geologic evidence and supported with very limited measurement data, some abnormal rock behavior was noted during tunnel driving. These occurrences were observed at the south heading concurrent with excavation as extensive rock fallout or overbreak and with several instances of "popping rock". A11 occurred in the south heading and across the portion of the route with the greatest overburden. Occurrences well all in ground supported by rock bolts or 6 -inch sets. This rock behavior did not affect tunne1 progress. 


\section{REFERENCES}

1. Aisiks, E. G., and N. H. Danziger. Ventilation Research Program at Cascade Tunne1, Great Northern Railway. Am. Railway Eng. Assoc., Bu11. 622, (Proc. v. 71), September-October 1969, pp. 108-128.

2. American Railway Engineering Association. Lining Railway Tunnels. V. I, sec. 8, Part 11, Chicago, I11., 1962, 15 pp.

3. - Tunne1s, Specifications for Excavation of Tunnels. V. I, sec. 1, Part 8, Chicago, I11., 1966, 8 pp.

4. American Society of Civil Engineers. Flathead Tunnel. Civil Engineering, v. 39, No. 12 , December 1969 , pp. 53.

5. Calkins, F. C., and D. F. MacDona1d. A Geologica1 Reconnaissance in Northern Idaho ând Northwestern Montana. U.S. Geo1. Survey Bu11.384, 1909,112 pp.

6. Clark, C. M., and G. Spann. Tunnel Lining Practice on Delaware Aqueduct. J. Am. Concrete Inst., v. 12, No. 4, February 1941, pp. 325-348;

Discussion, v. 13, No. 2, November 1941, pp. 348.1-348.6。

7. Coves, El1iott (ed.). The Manuscript Journa1s of Alexander Henry and of David Thompson. Ross and Haines, Inc., Minneapolis, Minn., v• II, 1897 , pp. $447-1027$.

8. Daly, R. A. Geology of the North American Cordillera at the Forty-Ninth Para11el. Can. Geo1. Survey, Mem. 38, 1912, 378 pp。

9. Engineering News-Record. Relocations at Libby Dam--Cost $\$ 120$ mil1ion. V. 180 , No. 8, Feb. 22, 1968, pp. 48-50.

10. Contractor-Built Rig Leads Fast Rai1-Laying Procession. V. 185, No. 5, July 30, 1970, pp. 22-23.

11. Libby Dam Warms up Concrete Buckets Again。 V. 186, No. 12, Mar. 25, 1971, pp. 22-24.

12. Galster, R. W. Engineering Geology at the Flathead Tunnel, Libby Project, Montana. Proc. 6th Annu. Eng. Geol and Soil Mech. Symp., Boise, Idaho, Apr. 17-19, 1968. Idaho Dept. of Highways, 1969, pp. 347-355.

13. - Private communication, Ju1y 6, 1967. Available upon request from Corps of Engineers, Seattle District, 1519 Alaskan Way South, Seattle, Wa. 98134.

14. Gibson, R. Geology and Ore Deposits of the Libby Quandrangle, Mont. U.S. Geo1. Survey Bu11. 956, 1948, 131 pp. 
15. Gibson, R., W. F. Jenks, and I. Campbe11. Stratigraphy of the Belt Series in Libby and Trout Creek Quadrangles, Northwestern Montana and Northern Idaho. Geo1. Soc. America Bul1., v. 52, No. 3, 1941, pp. 363-379.

16. Gilmour, E. H. Geology of the Southwestern Part of the Stryker Quadrangle, Northwestern, Montana. M.S. Thesis, Univ. Montana (Missoula), 1964, 63 pp.

17. Hali, F. W. Geology of the Northwest Pleasant Valley Quadrangle, Montana. M.S. Thesis, Univ. Montana (Missoula), 1962, 55 pp.

18. Harrison, J. E., and A. B. Campbe11. Correlations and Problems in Be1t Series Stratigraphy, Northern Idaho and Western Montana. Geol. Soc. America Bu11., v. 74, No. 6, December 1963, pp. 1413-1428.

19. Haske11, D. C. (ed.). On Reconnaissance for the Great Northern, Letters of C. F. B. Haske11, 1899-1891. Bu11. N. Y. Public Library, v. 52, No. 2, February 1948, pp. 55-77.

20. Hubbert, M. K. Mechanics of Hydraulic Fracturing. AIME Trans., v. 210 (Petro1.), 1957, pp. 153-167.

21. Inland Empire Magazine. Libby Dam Revises Rail History. SpokesmanReview, v. 84, No. 113, Sept. 4, 1966, p. 5.

22. Jacobs, J. D. Movable Trackways for Tunne1s and Method for Moving Tunne1 Floorings. U.S. Pat. 3,138,327, June 23, 1964, 14 pp.

23. The Sliding Floor, A Construction System for Faster Tunne1 Driving. Jacobs Associates, San Francisco, Calif., February 1968, 9 pp.

24. Tunne1 and Shaft Systems Today and Tomorrow. Ch. 6 in Rapid Excavation, Problems and Progress, ed. by D. H. Yardley. American Institute of Mining, Metallurgical, and Petroleum Engineers, New York, $1970,410 \mathrm{pp}$.

25. Johns, W. M. Geology and Mineral Deposits of Lincoln and Flathead Counties, Montana. Bul1. 79, Montana Bureau Mines and Geol., September $1970,182 \mathrm{pp}$.

26. Johnson, 0. W. Story of Tobacco Plains Country. Claxton Printers, Caldwe11, Idaho, 1950, $273 \mathrm{pp}$.

27. Kerr, D. J., F. Mears, and J. C. Baxter. The Eight-Mile Cascade Tunnel, Great Northern Railway. Proc. ASCE, v. 57, No. 2, February 1931, pp. $183-268$.

28. Obert, L., and W. I. Duva11. Rock Mechanics and the Design of Structures in Rock. John Wiley of Sons, Inc., 1967, 650 pp. 
29. Pacific Builder and Engineer. Wa1sh-Groves Punch the Big Hole. V. 73, No. 10, October 1967 , pp. 70, 75, 76 .

30. Parsons, E. W. Using Precast Reinforced-Concrete Sets in the Pioneer Tunnel of Great Northern Railway's Cascade Tunnel, King County, Washington. BuMines IC 7858, 1958, $10 \mathrm{pp}$.

31. Procter, R. V., and T. L. White. Rock Tunneling With Steel Supports, with an Introduction to Tunnel Geology by Kar1 Terzaghi. Commercial Shearing and Stamping Co., Youngstown, Ohio, 1946, 278 pp.

32. Railway Track and Structures. AREA Committee Inspect Burlington Northern Libby Line Change. V. 66, No. 9, September 1970, pp. 18-22.

33. Ransome, F. L. Ore Deposits of the Coeur d'Alene District, Idaho. U.S. Geo1. Survey Bu11. 260, 1905, pp. 274-303.

34. Ransome, F. L., and F. C. Calkins. The Geology and Ore Deposits of the Coeur d'Alene District, Idaho. U.S. Geo1. Survey Prof. Paper 62, 1908, 203 pp.

35. Richards, J. C. Loads on Tunnel Supports. Memo, U.S. Army Corps of Engineers, Resident Engineer's Office, Libby, Mont., Mar. 22, 1967 , $14 \mathrm{pp}$.

36. Geologic Conditions Relative to Fallout which Occurred at Station $3240+53$ to 3241+28. Memo, U.S. Army Corps of Engineers, Resident Engineers's Office, Libby, Mont., Sept. 20, 1967, 5 pp.

37. Ross, C. P. The Belt Series in Montana, with a geologic map compiled by B. A. L. Skipp and a section on Paleontologic Criteria by R. Rezak. U.S. Geo1. Survey Prof. Paper 346, 1963, 122 pp.

38. Sacrison, H. E. Constructing the Flathead Railroad Tunne1. J. Construction Div., ASCE, v. 97, No. CO 1, March 1971, paper 8009, pp. 127-145.

39. Private Communication, Dec. 16, 1969. Available upon request from Walsh Const. Co., San Mateo, Calif.

40. Sieber, Otto. Clicks Replace the Clickety-Clack on New Railroad Sections. Pacific Builder and Eng., v. 77, No. 3, Feb. 5, 1971, pp. 20-23.

41. Tuthi11, L. H. Tunne1 Lining Methods in Concrete. J. Am. Concrete Inst., v. 37, No. 1, September 1940, pp. $29-47$.

42. - Tunne1 Lining With Pumped Concrete. J. Am. Concrete Inst., v 68, No. 4, Apri1 1971, pp. 252-262.

43. U.S. Army Corps of Engineers (Seattle District). Specifications for Tunne1 Excavation. CIVENG-45-108-66-31, Sec. 4, 1966, 12 pp. 
44. _ Flathead Tunne1, Holing-Out. June 21, 1968, 13 pp.

45. U.S. Department of Commerce. Loca1 C1imatologica1 Data--Ka1ispe11, Montana, July 1966-Ju1y 1969. Weather Bureau office, Environmenta1 Science Service Administration, Kalispe11, Mont., 78 pp.

46. Western Construction Magazine. Portaling-In the Flathead Tunnel. V. 42, No. 1, January 1967 , pp. 48-50.

47. - Montana's Libby Reservoir Project. V. 43, No. 8, August 1968, pp. 50 and 58 .

48. Wood, C. R. Lines West, A Pictorial History of the Great Northern Railway Operations and Motive Power from 1887 to 1967. Superior Publishing Co., Seattle, Wash., 1967, 192 pp. 


\section{APPENDIX A--PROJECT SUMMARY}

Table A-1 presents a summary of tunneling activity for the Flathead Tunnel. The table is broken into categories of general progress, excavation, drilling and blasting, mucking, steel sets, and rock bolting.

TABLE A-1. - Project summary

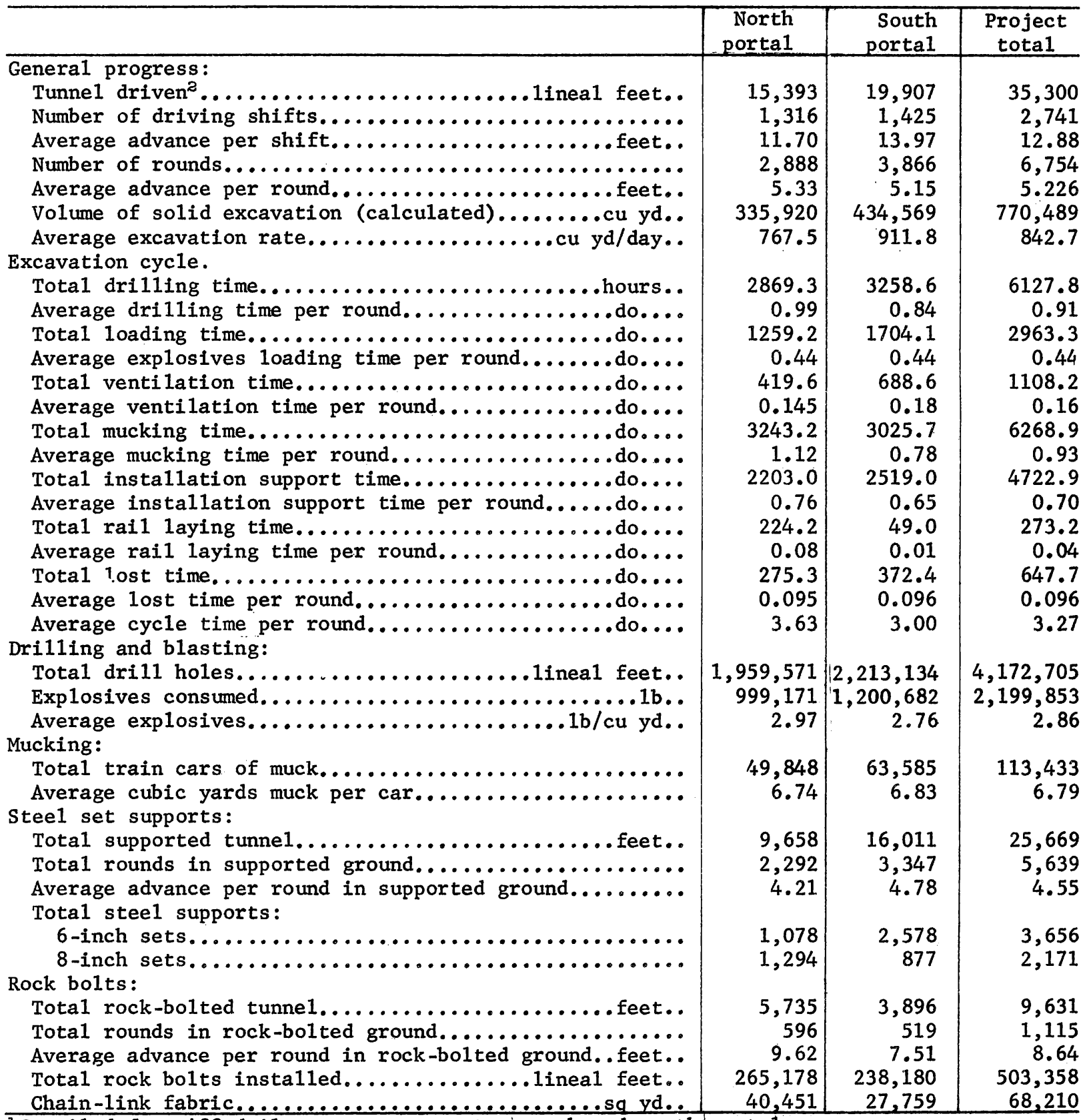

${ }^{1}$ Compiled from 488 daily progress reports, north and south portals.

${ }^{2}$ Excludes cut-and-cover portal sections. 
Table A-2 is an abstract of 21 selected material bid items from the invitation for bid, Flathead Tunnel. Labor was under union contract at wage rates prevalent at the time for the Pacific Northwest. At the peak of employment, nearly 350 men were employed. Each heading usually carried a crew of 22 to 26 men during tunnel excavation. These crews worked at the face until relieved by the following shift. Crews were scheduled three shifts per day, 6 days per week, with a maintenance crew working the seventh day. Concrete operations were done by a total work force of about 45 men per shift. Concreting was done three shifts per day, 5 days per week.

TABLE A-2. - Select tunne1 bid items ${ }^{1}$

\begin{tabular}{|c|c|c|c|}
\hline Item & Quantity & Unit price & $\begin{array}{l}\text { Bid } \\
\text { estimate }\end{array}$ \\
\hline Tunne1. approaches: & & & \\
\hline clearing and grubbing.......... & 195 acres......... & $\$ 1,000$ & $\$ 195,000$ \\
\hline Excavation, unclassified........ & $450,000 \mathrm{cu}$ yd...... & 3.00 & $1,350,000$ \\
\hline Tunne1: & & & \\
\hline 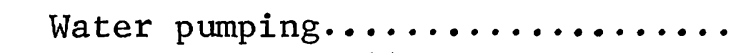 & 50 million cu ft... & .005 & 250,000 \\
\hline Exploratory drilling........... & 100 hr............ & 50.00 & 5,000 \\
\hline Feeler holes, tunnel........... & 80,000 1inea1 feet. & 3.30 & 264,000 \\
\hline Exploration holes, tunne1....... & 8,000 lineal feet.. & 12.00 & 96,000 \\
\hline Tunne1 excavation............. & 800,000 cu yd...... & 22.00 & $17,600,000$ \\
\hline Transformer, refuge bays......... & $35,000 \mathrm{cu}$ yd... & 25.00 & 875,000 \\
\hline Structura1 stee 1 supports....... & 6 mil1ion $1 \mathrm{~b} \ldots . .$. & .15 & 900,000 \\
\hline $\begin{array}{l}\text { Structural steel supports, } \\
\text { installation. }\end{array}$ & 4 miliion $1 b \ldots \ldots$ & .34 & $1,360,000$ \\
\hline Do........... & 2 million $1 b \ldots \ldots$. & .10 & 200,000 \\
\hline Rock bolts................. & 375,000 1inea1 feet & 3.00 & $1,125,000$ \\
\hline Chain-1ink fabric............. & 44,000 sq yd....... & 3.00 & 132,000 \\
\hline Portland cement....... & $307,000 \mathrm{bb} 1 \ldots \ldots$ & 5.50 & $1,688,500$ \\
\hline Concrete tunnel lining. & $194,000 \mathrm{cu}$ yd.. & 33.00 & $6,402,000$ \\
\hline Reinforcing stee1...... & $6,057,0001 \mathrm{~b} \ldots \ldots$ & 0.20 & $1,211,400$ \\
\hline Embedded pipe drainage.... & 22,000 lineal feet. & 5.00 & 110,000 \\
\hline $\begin{array}{l}\text { Placing backfil1 grout.... } \\
\text { Tunne1 drainage system: }\end{array}$ & $10,000 \mathrm{cu}$ ft...... & 7.00 & 70,000 \\
\hline 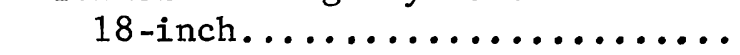 & 33,860 1ineal feet. & 20.50 & 694,130 \\
\hline 24-inch............. & 39,130 1ineal feet. & 23.50 & 919,555 \\
\hline Random backfil1........ & $265,000 \mathrm{cu}$ yd....... & 1.00 & 265,000 \\
\hline
\end{tabular}

${ }^{1}$ Abstracted from invitation for bids, seria1 45-108-66-31.

Table A-3 is summary of support costs for the Flathead Tunnel. Note that the combined cost of temporary steel support and permanent concrete lining amounts to 53.15 percent of the total tunnel cost. 
TABLE A-3. - Summary of excavation and support costs

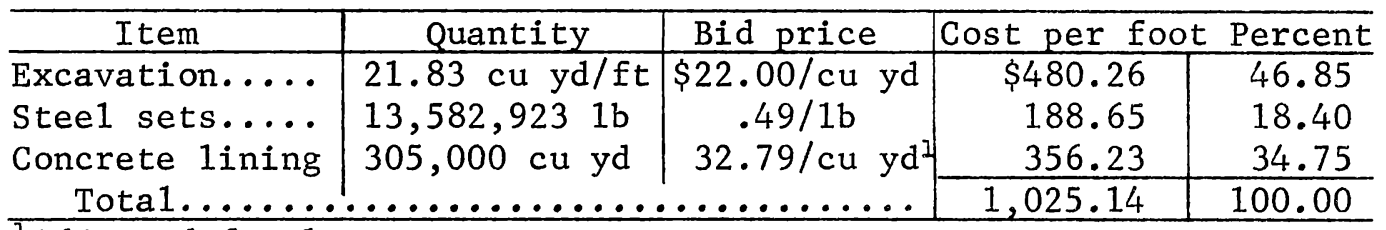

${ }^{1}$ Adjusted for lean concrete.

Figure A-1 shows the schedule of major tunnel activities with accompanying daily high and low temperature profiles. The temperature records shown are for Kalispe11, Mont. Actual jobsite temperatures would be consistently lower. No official weather records were maintained at the tunne1 jobsite; plotted data were supplied by U.S. Department of Commerce, Environmenta1 Science Services Administration (ESSA). Note the scheduling of major underground operations with winter temperatures.

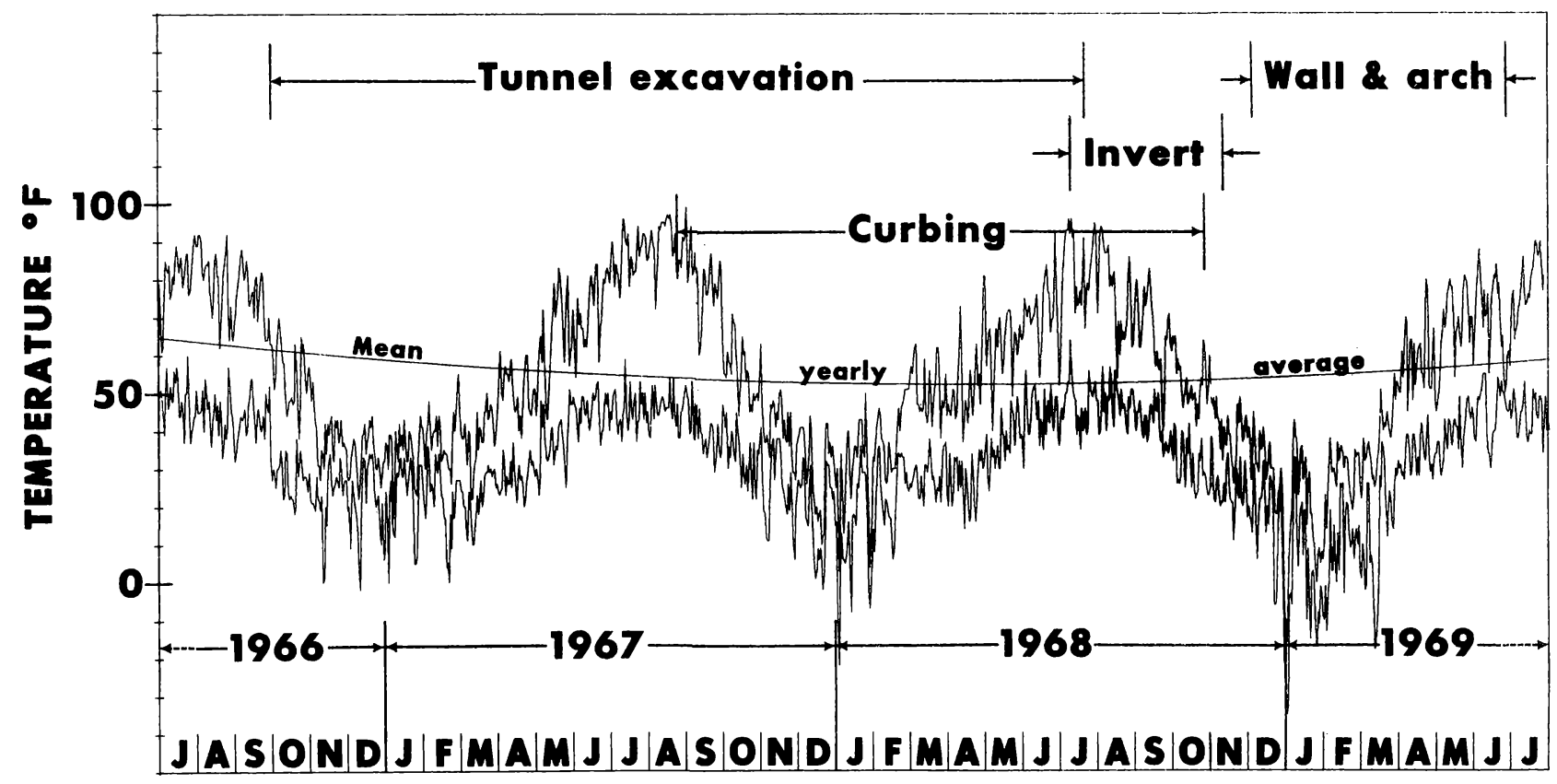

FIGURE A-1. - Schedule of major tunnel activities. 
Table A-4 presents a listing of major tunnel excavation plant and equipment. Both headings were each equipped with complete tunnel driving plant and equipment. Therefore, the total equipment makeup would be twice that shown.

TABLE A-4. - Tunne1 excavation equipment, each heading

\begin{tabular}{|c|c|c|}
\hline Quantity & Item & Description or use \\
\hline $\overrightarrow{25,000 \text { feet }}$ & Track............... & $80-1 b$ rail, $42-$ inch gage. \\
\hline 1 & sliding floor.......... & 418 feet, 3 operating sections. \\
\hline 1 & Dri11 jumbo........... & 3-deck, rail-mounted dril1 jumbo. \\
\hline 2 & Mucking machine........ & Conway mode1 100-2. \\
\hline 5 & Diese1 1ocomotive...... & P1ymouth mode1 $25 \mathrm{~T}$, JMD. \\
\hline 36 & Muck car............. & Moran side-dump cars, $13 \mathrm{cu}$ yd. \\
\hline 4 & Steel support car....... & $\begin{array}{l}\text { 15-foot-1ong flat cars adapted for } \\
\text { transportation of tunnel supports. }\end{array}$ \\
\hline 9 & F1at car........ & Transport timber and other materials. \\
\hline 1 & Fan line car..... & $\begin{array}{l}\text { Designed to transport and hydraulically } \\
\text { place } 30 \text {-foot lengths of } 46 \text { inch diam- } \\
\text { eter ventilation line. }\end{array}$ \\
\hline 1 & Powder car............. & $\begin{array}{l}\text { 20-foot-1ong car specially designed for } \\
\text { explosives transportation. }\end{array}$ \\
\hline 1 & Man car....... & 28 -foot enclosed man-car. \\
\hline 1 & Timber jumbo... & $\begin{array}{l}\text { Rail-mounted jumbo to allow work on } \\
\text { tunnel supports independent of tunnel } \\
\text { excavation. }\end{array}$ \\
\hline 2 & California switch... & Movable switching platforms. \\
\hline 6 & Ventilation fan... & $\begin{array}{l}\text { Placed in tunnel at about } 4,000 \text {-foot } \\
\text { intervals. }\end{array}$ \\
\hline 5 & Air compressor. & Gardner-Denver electric compressor. \\
\hline 1 . & Heading system. & $\begin{array}{l}\text { Ventilation line, compressed air line, } \\
\text { drilling water line, discharge water } \\
\text { line (north heading only). }\end{array}$ \\
\hline 1 & Car dumper....... & Moran electric/hydraulic car dumper. \\
\hline 2 & Caterpil1ar D-8........ & To move muck away from car dumper. \\
\hline 1 & Caterpillar Motor grader & Road maintenance. \\
\hline 1 & Caterpillar 988 loader.. & To load muck for surface disposal. \\
\hline 2 & Euclid dump trucks...... & To move muck to embankment fi 11 \\
\hline 1 & Backhoe 1oader.......... & Case mode $1 \mathrm{~W}-7$ \\
\hline 1 & Electrica1 system...... & $\begin{array}{l}350,000 \text { circular mi } 11 \text { primary power } \\
\text { cable with } 300-\mathrm{kV}-\mathrm{A} \text { heading trans - } \\
\text { formers and } 150-\mathrm{kV}-\mathrm{A} \text { ventilation fan } \\
\text { transformers, underground approved. }\end{array}$ \\
\hline
\end{tabular}




\section{APPENDIX B--SAFETY}

Safety provisions were made an integral part of the tunnel contract. Applicable safety specifications included publications of the Corps of Engineers, the Bureau of Mines, and the U.S. Forest Service. Corps of Engineers Safety Manual EM 385-1-1 provided basic safety criteria. ${ }^{1}$

Safety inspection of the project was under the direct authority of the Safety Office, Corps of Engineers. At the request of the Resident Engineer, periodic underground safety inspections were also made by the Bureau of Mines.

Movable underground equipment, such as dril1 jumbo, mucker, locomotives, and muck cars were painted entirely white for maximum visibility in the tunnel. Operator-driven equipment and outside rubber-tired equipment al1 carried backup alarms and seat belts. Drill operators wore ear plugs. Surface supervision used radio communications extensively and underground personnel had ready access to telephones. Safety protective gear was required for all personne1. A dryhouse was provided at each porta1.

Diese1-powered 1ocomotives for underground use were Bureau of Mines approved by schedules 24 and $31 .^{2}$ Monitoring of tunnel atmosphere at various places was also regularly done during both excavation and concreting.

Medical facilities were maintained at each portal throughout construction. A registered nurse and ambulance were on 24 -hour standby at each porta1 facility.

$$
\text { TABLE B-1. - Accident statistics, Flathead Tunne1 }
$$

Total construction period reported........... 2 years, 9 months

Total manhours of exposure.............. 2,731,103 hours

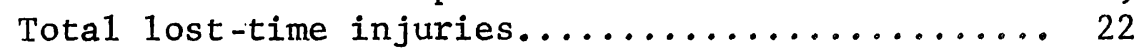

Injury severity rate, per million manhours...... 5,975

Injury frequency rate, per miliion manhours...... 8.06

IU.S. Army Corps of Engineers. Safety--General Safety Requirements. Manua1 EM 385-1-1, 1967, 171 pp.

${ }^{2}$ U.S. Bureau of Mines. Procedure for Testing Mobile Diese1-Powered Equipment for Non-Coal Mines (schedule 24). Federal Register, v. 14, No. 67, Apr.8, 1949, 1 p.; v. 14, No. 113, June 14, 1949, 7 pp.

U.S. Bureau of Mines. Mobile Diese1-Powered Equipment for Non-Coa1 Mines: Tests for Permissibility and Suitability; Fees. Federa1 Register, v. 20, No. 80, Apr. 23, 1955, 2 pp. (amendment to schedule 24).

U.S. Bureau of Mines. Mobile Diese1-Powered Transportation Equipment for Gassy Noncoal Mines and Tunnels: Tests for Permissibility and Suitability: Fees. (schedule 31). Federal Register, v. 26, No. 14, Jan. 24, 1961, 7 pp. 
Comparable tunneling accident statistics from the previous decade and reported by the Bureau of Mines are described in IC 8114 ( $p$. 34) ${ }^{3}$ for work on the West Delaware Aqueduct.

Three lost-time accidents included one rockfall injury, one fatality when a workman was working on a compressed airline, and another fatality when a workman was involved in a trackless haulage accident. The fatalities occurred after tunneling, but before concrete invert lining had been completed. The rockfall injury occurred shortly after tunnel excavation began.

Outstanding mention should be made of an intensive, wel1-prepared and we11-presented safety indoctrination given to a11 employees by the contractor. This was done by both audio and visual techniques. At this rather remote locality, experienced underground personnel were not available, and most personnel were recruited from the local logging industry. Therefore, the good accident record achieved in this project with inexperienced personnel can be attributed to this safety indoctrination.

${ }^{3}$ Rachunis, W., A. A. Sinicrope, and J. A. Moore. Safety Practices in Shaft Sinking and Tunneling: West Delaware Aqueduct. BuMines IC 8114, 1962, $35 \mathrm{pp}$. 


\section{APPENDIX C--WORLD RAILROAD TUNNELS}

Because of the increasing amount of tunneling activity in the last decade, particularly in Japan, it is appropriate for this report to tabulate a partial list of the world's longest railroad tunnels, complied from the best available sources. These are for hardrock tunnels only and do not include subway-type construction. As shown in table $\mathrm{C}-1$, the Flathead Tunnel presently ranks $13 \mathrm{th}$, but in the $1970^{\prime} \mathrm{s}$ it will become about $15 \mathrm{th}$, when several more planned railroad tunnels in Japan will begin construction.

TABLE C-1. - World railroad tunnels

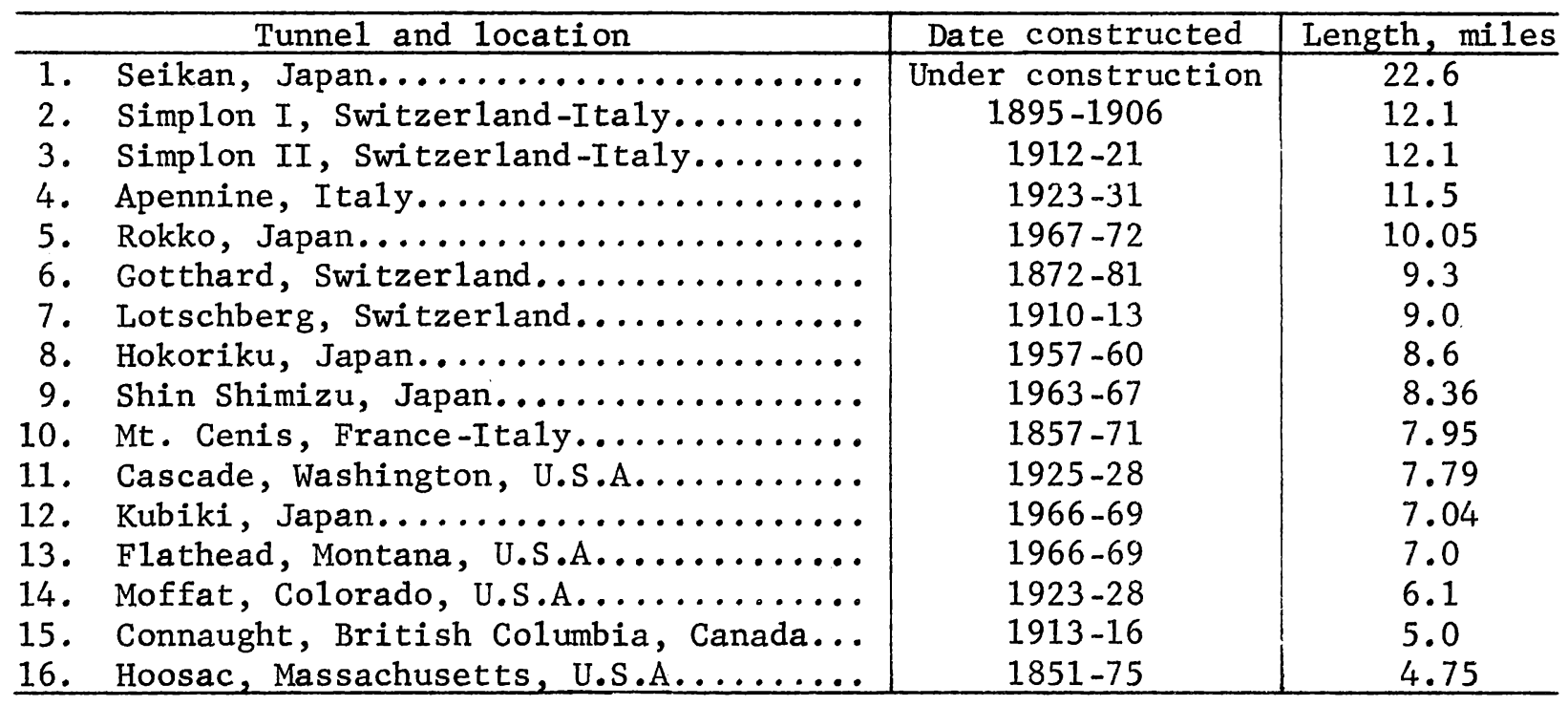

The three tunnels following the Flathead Tunnel in table C-1 are comparable North American railroad tunnels. The worldwide 1ist of railroad tunnels becomes extreme1y lengthy for tunnels under $6 \mathrm{miles}$. This 1ist of only a few tunnels has a total length of over $150 \mathrm{miles}$. 


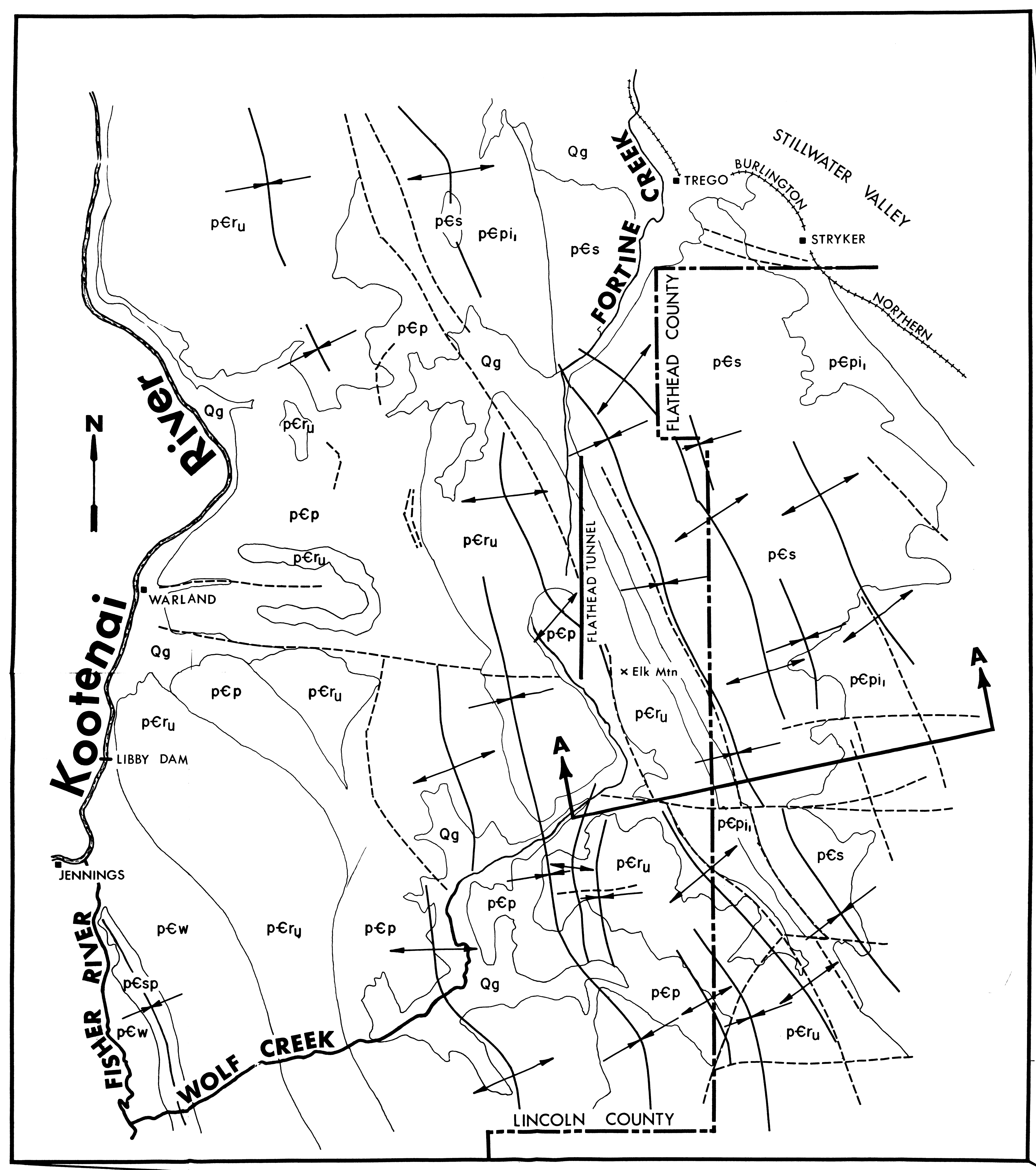

\section{Sedimentary Rocks}

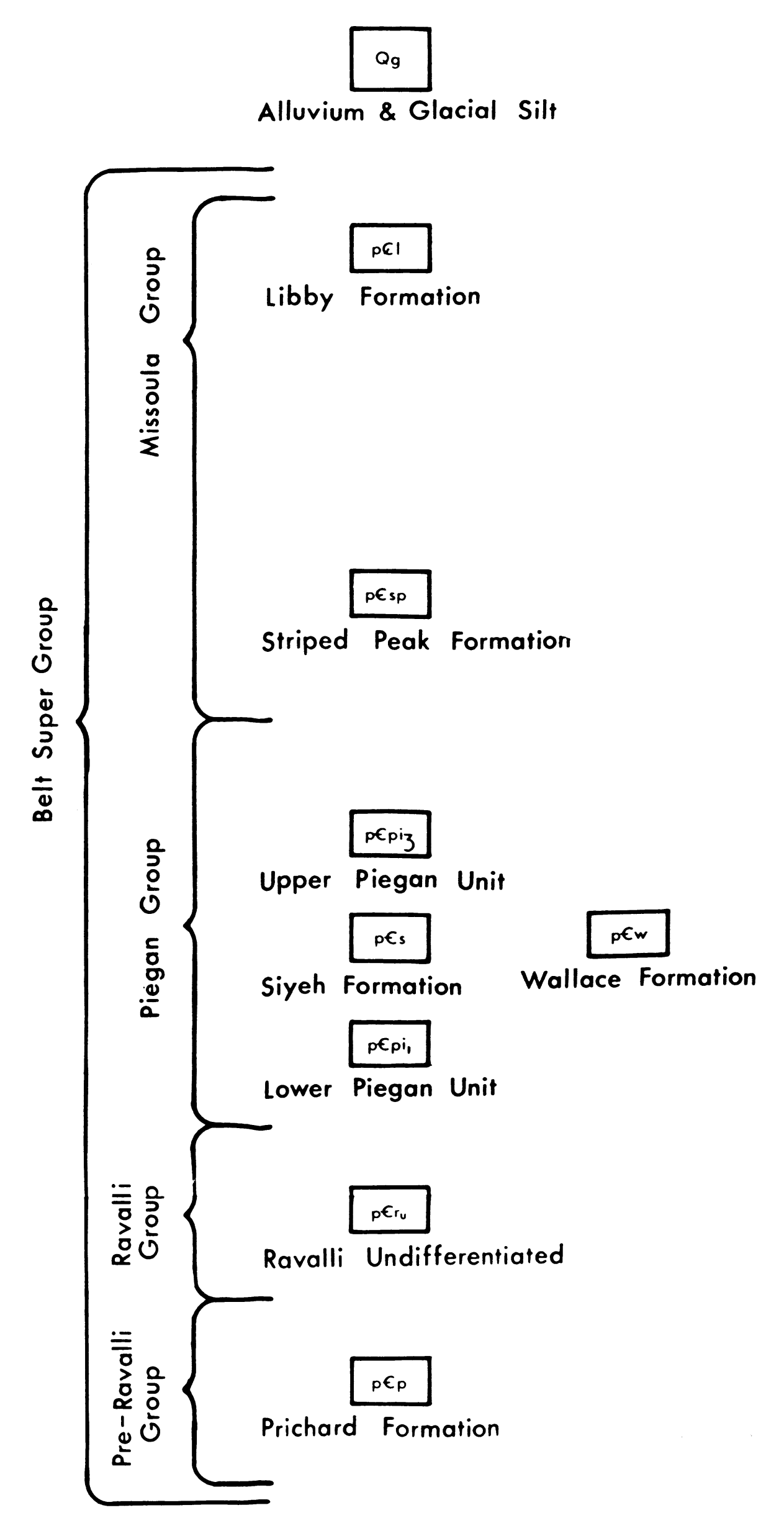

\section{LE GEND}

-.-- Foult

Antricline
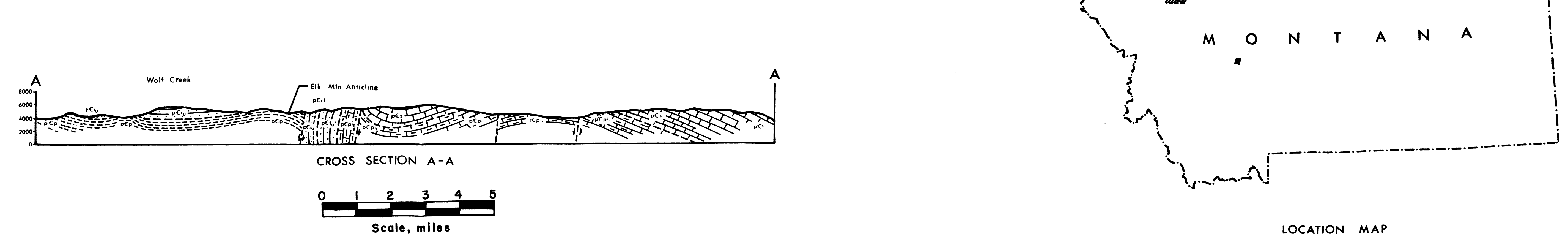

LOCATION MAP 

